MAURICIO PALLOTTA RODRIGUES

\title{
OS EFEITOS FISCAIS E PREVIDENCIÁRIOS DA SENTENÇA TRABALHISTA
}

\author{
Dissertação de Mestrado \\ Orientador: Professor Dr. Sérgio Pinto Martins
}

UNIVERSIDADE DE SÃO PAULO

FACULDADE DE DIREITO

São Paulo-SP 
MAURICIO PALLOTTA RODRIGUES

\section{OS EFEITOS FISCAIS E PREVIDENCIÁRIOS DA SENTENÇA TRABALHISTA}

Dissertação apresentada à Banca Examinadora do Programa de Pós-Graduação em Direito, da Faculdade de Direito da Universidade de São Paulo, como exigência parcial para obtenção do título de Mestre em Direito, na área de concentração Direito do Trabalho e da Seguridade Social, sob a orientação do Prof. Dr. Sérgio Pinto Martins.

UNIVERSIDADE DE SÃO PAULO

FACULDADE DE DIREITO

São Paulo-SP 
Nome: RODRIGUES, Mauricio Pallotta.

Título: Os efeitos fiscais e previdenciários da sentença trabalhista

Dissertação apresentada à Banca Examinadora do Programa de Pós-Graduação em Direito, da Faculdade de Direito da Universidade de São Paulo, como exigência parcial para obtenção do título de Mestre em Direito, na área de concentração Direito do Trabalho e da Seguridade Social, sob a orientação do Prof. Dr. Sérgio Pinto Martins.

Aprovado em: 1

\section{Banca Examinadora}

Prof. Dr. Instituição:

Julgamento: Assinatura:

Prof. Dr. Instituição:

Julgamento: Assinatura:

Prof. Dr. Instituição:

Julgamento: Assinatura: 
Dedico esse trabalho à Deus, em primeiro lugar, pois foi a fé que me permitiu superar os obstáculos e atingir o meu objetivo. Dedico, também, à minha família e amigos, sem os quais não teria sido possível a conclusão desse projeto. 


\section{AGRADECIMENTOS}

Tenho a convicção de que para se obter o sucesso em qualquer área que seja é imprescindível que reconheçamos a necessidade do apoio das pessoas que se importam com o nosso desenvolvimento. Portanto, quero tornar público os meus agradecimentos àqueles que de alguma forma contribuíram para o resultado final desta dissertação de mestrado.

Em primeiro lugar agradeço aos meus pais, Maria Cecilia Carvalho Pallotta e Evaristo José Rodrigues Neto, que são a razão de minha existência e os responsáveis pela formação do meu caráter.

Agradeço à minha irmã, Ana Beatriz Pallotta Rodrigues, que tem a mesma formação que a minha e dedicou seu precioso tempo para me auxiliar em pesquisas e com ideias.

À minha esposa, Angélica Jacob D'Amico, que me acompanha por quase dez anos nessa jornada e sempre será uma grande amiga, com quem posso compartilhar os meus projetos.

Ao meu orientador, Sérgio Pinto Martins, que fez as críticas e sugestões necessárias para engrandecer a pesquisa e o texto final, quem, por óbvio, não tem qualquer responsabilidade por eventuais incorreções que possam ser apontadas.

Por fim, agradeço à minha equipe de trabalho, que me deu o suporte e a segurança para que eu pudesse me dedicar ao tema. Em especial, à Beatriz Moraes, minha fiel escudeira, estudante de direito, que se dedicou arduamente para me ajudar na conclusão deste estudo. 
"Só existem dois dias no ano que nada pode ser feito. Um se chama ontem e o outro se chama amanhã, portanto hoje é o dia certo para amar, acreditar, fazer e principalmente viver". 


\section{RESUMO}

RODRIGUES, Mauricio Pallotta. Os efeitos fiscais e previdenciários da sentença trabalhista. 2015. 157 f. Dissertação (Mestrado) - Faculdade de Direito da Universidade de São Paulo, São Paulo, 2015.

Pretende-se com o presente trabalho de pesquisa abordar, do ponto de vista teórico, as especificidades da execução ex officio das contribuições sociais no âmbito trabalhista. A problemática gira em torno da natureza jurídica da contribuição social e do procedimento sui generis de execução na justiça do trabalho. A natureza tributária impõe uma série de implicações que devem ser enfrentadas pelo operador do direito, principalmente no que pertine as normas aplicáveis na constituição e exigência do crédito tributário. O objeto do trabalho consistirá na análise do procedimento de execução que deve ser adotado, visando o respeito dos demais institutos vinculados à execução tributária, inclusive, a prescrição e a decadência. Serão identificadas as peculiaridades desta competência concorrente, incluída a questão da possibilidade de utilização de períodos cujo vínculo tenha sido reconhecido por sentença trabalhista, para fins de obtenção de benefícios previdenciários.

Palavras-Chave: Contribuição Previdenciária, Execução, Justiça do Trabalho, Incidência Normativa, Constituição do Crédito, Obtenção de Benefício. 


\begin{abstract}
RODRIGUES, Mauricio Pallotta. The Implications of Labour Tribunal Decisions on Taxation and Social Security Benefits. 2015. 157 p. Thesis (Master) Faculty of Law, University of São Paulo, São Paulo, 2015.

The present research intends to approach, from a theoretical point of view, the specific ex officio implementation of social security contributions. The issue revolves around the legal nature of social security contribution and the sui generis execution procedure in the labour courts. The nature of this tax (contribution to social security) imposes a number of implications that must be addressed by the legal practitioner, especially as it pertains to the rules in the constitution and requirements of taxes owning. The objective of the study will be the analysis of the execution procedure to be adopted for compliance with other laws, rules, or regulations relating to tax enforcement, including any statutes of limitation. The peculiarities of this concurrent jurisdiction will be identified, including the question of whether retroactive decisions of labor tribunals can be used to obtain social security benefits.
\end{abstract}

Keywords: Social Security Contributions, Execution, Labour Law, Legal Incidence, Tax Enforcement, Obtaining benefits. 


\section{SUMÁRIO}

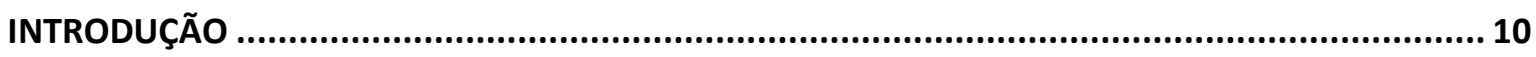

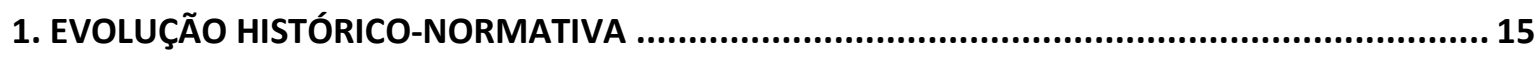

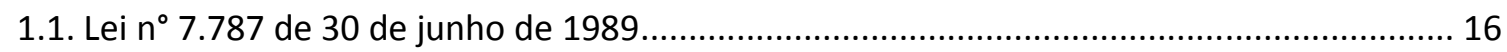

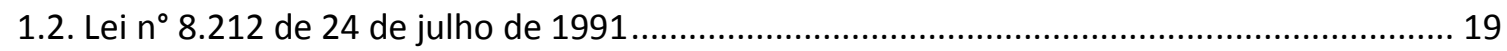

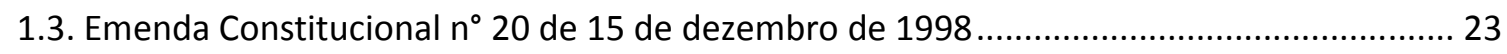

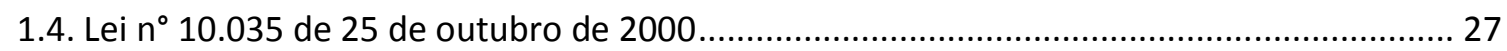

1.5. Emenda Constitucional $n^{\circ} 45$ de 30 de dezembro de 2004 ................................................. 35

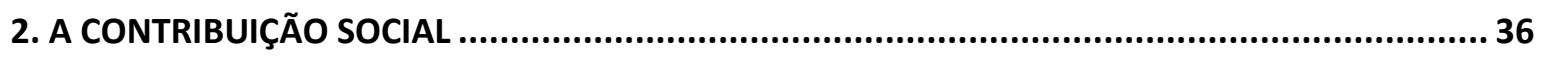

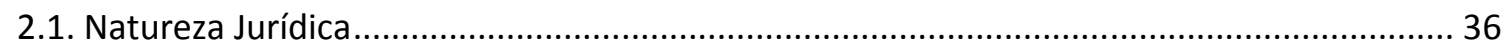

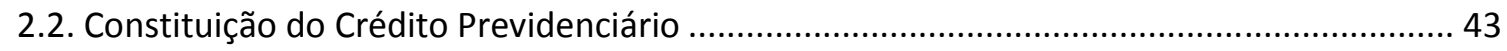

2.3. Impacto do e-Social no Lançamento Tributário ....................................................................... 49

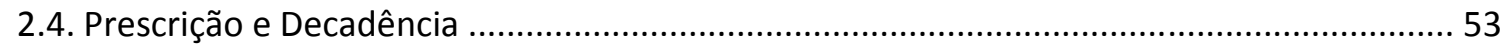

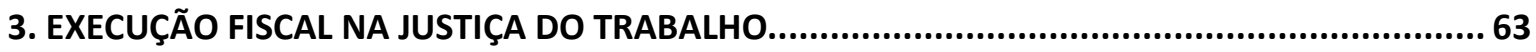

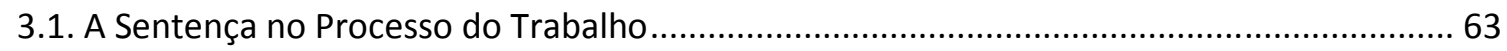

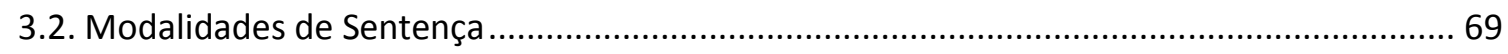

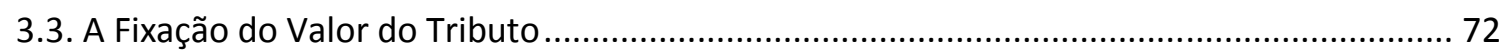

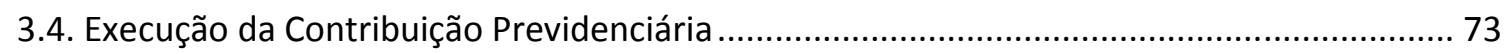

3.5. A Prescrição Tributária Intercorrente no Processo do Trabalho ........................................... 81

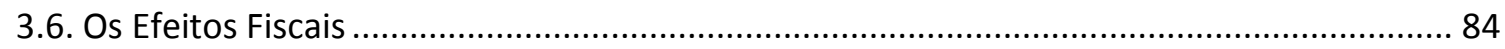

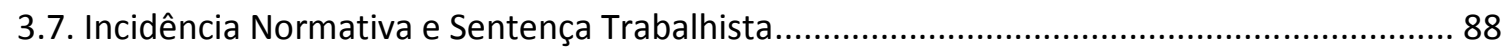

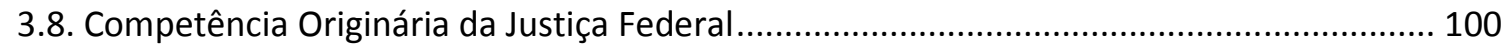

3.9. Due Process of Law e a Ausência de Impugnação Específica............................................. 104

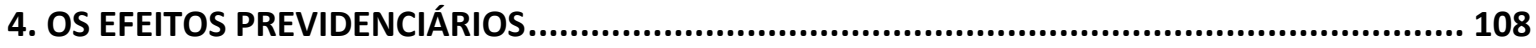

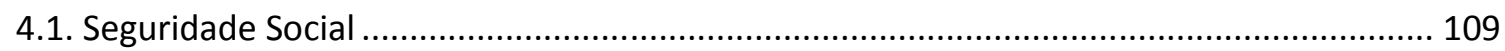

4.2. Arrecadação Enquanto Mecanismo de Manutenção do Sistema........................................ 114

4.3. Previdência Social e a Concessão de Benefícios ................................................................ 117

4.4. A Reciprocidade Contributiva e a Execução de Ofício ....................................................... 126

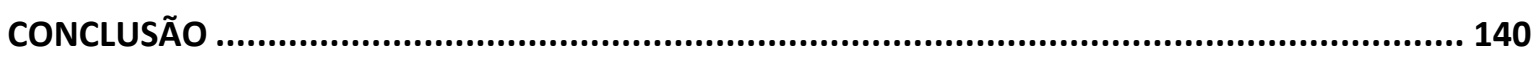

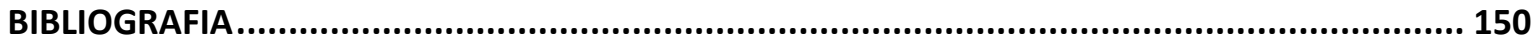




\section{LISTA DE ABREVIATURA E SIGLAS}

ABDPC - Academia Brasileira de Direito Processual Civil

AC - Acórdão

AFRFB - Auditor-Fiscal da Receita Federal do Brasil

AGTR - Agravo de Instrumento

Al - Auto de Infração

$\mathrm{AL}$ - Alagoas

ARO - Aviso para Regularização de Obra

ART - Artigo

CC - Código Civil

Ce - Critério espacial

CEF - Caixa Econômica Federal

CF - Constituição Federal

Cit - Citatum

CLT - Consolidação das Leis do Trabalho

$\mathrm{Cm}$ - Critério material

CNIS - Cadastro Nacional de Informações Sociais

COFINS - Contribuição para Financiamento da Seguridade Social

$\mathrm{Cp}$ - Critério pessoal

CPC - Código de Processo Civil

$\mathrm{Cq}$ - Critério quantitativo

CRFB - Constituição da República Federativa do Brasil

$\mathrm{Ct}$ - Critério temporal

CTN - Código Tributário Nacional

CTPS - Carteira de Trabalho e Previdência Social

DCG - Débito Confessado em GFIP

DEJT - Diário Eletrônico da Justiça do Trabalho

DISO - Declaração e Informação sobre Obra

ED - Embargos de Declaração

FGTS - Fundo de Garantia do Tempo de Serviço

GFIP - Guia de Recolhimento do Fundo de Garantia do Tempo de Serviço e Informações à Previdência Social

IAPAS - Instituto de Administração Financeira da Previdência e Assistência Social 
INSS - Instituto Nacional do Seguro Social

LDC - Lançamento do Débito Confessado

MCJF - Manual de Cálculo da Justiça Federal

MPS - Ministério da Previdência Social

NL - Notificação de Lançamento

OIT - Organização Internacional do Trabalho

PROC - Processo

RE - Recurso Extraordinário

REL - Relator

RFB - Receita Federal do Brasil

Sa - Sujeito ativo

SEFIP - Sistema Empresa de Recolhimento do FGTS e Informações à Previdência Social

$\mathrm{Sp}$ - Sujeito passivo

SPED - Sistema Público de Escrituração Digital

STF - Supremo Tribunal Federal

TEM - Ministério do Trabalho e Emprego

TRF - Tribunal Regional Federal

TRT - Tribunal Regional do Trabalho

TST - Tribunal Superior do Trabalho 


\section{INTRODUÇÃO}

O presente trabalho de pesquisa abordará, do ponto de vista científico, as especificidades da execução ex officio das contribuições sociais previstas na alínea "a" do inciso I e no inciso II, ambos do artigo 195 da Constituição, assim como os seus acréscimos legais, tudo em decorrência das sentenças proferidas no âmbito da justiça do trabalho.

A referida competência fora atribuída por força Emenda Constitucional №. 20 de 16 de dezembro de 1998, a qual foi posteriormente ratificada pela Emenda Constitucional ㄲo. 45 de 30 de dezembro de 2004, que inseriu o inciso VIII no art. 114 da Constituição Federal.

O problema gira em torno da natureza jurídica da contribuição social e do procedimento sui generis de introdução de uma norma jurídica individual e concreta tributária no direito positivo e a sua execução na Justiça do Trabalho.

É de conhecimento comum o entendimento jurisprudencial e doutrinário no sentido de se enquadrar a contribuição previdenciária como uma das espécies de tributo decorrente da prestação de serviço e com a finalidade específica de custeio da Seguridade Social.

Tal enquadramento impõe uma série de implicações jurídicas a serem enfrentadas por aqueles que pretendam estudar a incidência normativa mais a fundo, principalmente no que pertine às normas aplicáveis na constituição e exigência do crédito tributário.

Em que pese não concordar, não se pretende discutir sob o aspecto pragmático a competência da justiça do trabalho para efetivação da execução de ofício da contribuição social, até por que a matéria encontra-se pacificada, inclusive por previsão constitucional.

O objeto deste trabalho é a análise das inconsistências da incidência da norma e do procedimento de execução que deve ser adotado em decorrência da observância dos demais institutos vinculados a execução tributária, inclusive a prescrição e a decadência.

A pesquisa se fundamenta, principalmente, no método dialético e dedutivo. Em razão da evidente polêmica com que analisada a questão, especialmente quanto aos fundamentos de incidência normativa e a sustentabilidade dogmática da execução fiscal pela justiça do trabalho, é necessário que se proceda a análise 
e a discussão dos argumentos utilizados pelas vertentes doutrinárias e jurisprudenciais a respeito de sua aceitação ou rejeição, e mesmo sobre a forma de sua aplicação em ambiente trabalhista.

As teorias de incidência normativa, em especial a adotada por Paulo de Barros Carvalho, serão o corte metodológico utilizado para verificação das incongruências da execução de ofício da contribuição social na Justiça Laboral.

Em tese, não deveria ser possível a execução de uma obrigação fiscal jamais constituída formalmente. Trata-se de outorga constitucional de relativização das rígidas regras de constituição e exigibilidade do crédito tributário.

A União, através do Instituto Nacional do Seguro Social (INSS), sequer participa da lide trabalhista como terceiro interessado na fase de conhecimento, sendo que na de execução ingressa no polo ativo de cobrança da obrigação tributária, inclusive com legitimidade recursal para fazer valer o seu direito creditório.

Para atingir a finalidade pretendida necessária uma sucinta investigação da evolução histórico-normativa da exigibilidade da contribuição social em decorrência de julgados trabalhistas. Serão tratadas as principais alterações legislativas, as quais culminaram com as alterações no corpo da Consolidação das Leis do Trabalho, por meio da Lei $n^{\circ}$. 10.035/00, e na atual redação do inciso VIII do artigo 114 da Constituição, por força da Emenda Constitucional n. 45/03.

Após uma avaliação das diversas correntes e da definição da natureza jurídica da contribuição social, analisaremos como se dá a constituição do crédito tributário decorrente da contribuição social pelas vias ordinárias, enfatizando a importância dos instrumentos introdutores de normas jurídicas e as regras de pertencialidade a um sistema.

Ainda, será feita referência à importância do lançamento administrativo ou do auto de infração pelo descumprimento da norma de incidência para os fins tributários.

No tocante à contribuição social, em especial, por se tratar de tributo cujo lançamento acontece na modalidade por homologação, será apresentada a Guia de Recolhimento do Fundo de Garantia por Tempo de Serviço e de Informações à Previdência Social (GFIP), que é instrumento introdutor de norma individual prevista no ordenamento jurídico tributário para essa finalidade e se trata de 
importante fonte de informação previdenciária para os registros mantidos pelo INSS.

Diante das recentes alterações legislativas, serão avaliadas as eventuais consequências da implementação do e-Social em substituição a regra, até então vigente, de constituição administrativa do crédito tributário por meio da GFIP.

Por se tratar de um dos pilares da segurança jurídica, avaliaremos do ponto de vista tributário o momento em que se torna devida a contribuição social e o instante em que deixa de ser exigível como decorrência da aplicação dos institutos da prescrição e decadência.

Será atribuída a devida importância ao fato gerador da obrigação tributária, por ser esse o gatilho que impulsiona o dever do contribuinte fazer incidir a norma tributária por homologação, bem como, no caso de sua inércia, o marco inicial de contagem dos prazos decadencial e prescricional.

A União tem o poder e o dever de agir pró-ativamente para constituição de seus créditos, na medida em que possui legitimidade fiscalizatória para apurar os casos de sonegação e buscar, por meio de atos administrativos vinculados, a inscrição dos débitos fiscais na Dívida Ativa para que seja possível a sua execução judicial.

Em sequência, até como parte chave para as conclusões que se pretende alcançar com a presente pesquisa, serão feitas ponderações sobre a forma de execução fiscal na Justiça do Trabalho, iniciada com a dissecação da sentença trabalhista e suas várias modalidades, assim tratada como o instrumento capaz de introduzir no sistema trabalhista uma norma individual e concreta desta natureza, constituindo formalmente uma obrigação passível de execução.

Através da sentença trabalhista o magistrado pode declarar em seu antecedente a existência de um fato jurídico susceptível de incidência de mais de uma norma jurídica, em especial a fiscal-previdenciária, já que o fato gerador da contribuição social é exatamente o trabalho prestado pelo obreiro em favor do seu empregador.

Assim, diante dos efeitos fiscais produzidos como consequência lógica dos julgados trabalhistas, é importante verificar como se fixa o valor do tributo a ser recolhido, qual seria a sua base de cálculo, já que ele sequer é previamente constituído por meio de lançamento antes do início de sua execução. Nesse sentido, a avaliação do procedimento de liquidação de sentença, que é 
antecedente à fase de execução trabalhista, da qual a fiscal será sempre acessória, se mostra ainda mais relevante, posto que para que seja possível iniciar qualquer procedimento de obtenção forçada do crédito decorrente do fato gerador declarado por sentença trabalhista é imprescindível a prévia apuração do quantum debeatur.

Discutir-se-á, ainda, a sistemática da execução previdenciária pela Justiça do Trabalho, serão identificadas as peculiaridades desta competência concorrente, principalmente no que tange ao fato gerador da contribuição decorrente de sentenças condenatórias e homologatórias de acordo, as hipóteses de interrupção e suspensão da prescrição e decadência, da necessidade de observância do devido processo legal na constituição do crédito tributário, bem como a suas aplicações no âmbito trabalhista na execução de crédito tributárioprevidenciário.

A questão da incidência normativa é o corte metodológico para fins de verificação da validade da norma produzida pela Justiça do Trabalho com o intuito de se promover a execução forçada de tributos decorrentes do reconhecimento de fatos jurídicos capaz de impulsionar, também, a exigibilidade de arrecadação da contribuição social.

No último capítulo abordar-se-á a questão dos efeitos previdenciários da sentença trabalhista, da possibilidade de utilização de períodos cujo vínculo tenha sido reconhecido por sentença trabalhista para fins de obtenção de benefícios previdenciários.

É sabido que tanto o INSS, quanto a jurisprudência previdenciária, entendem ser a sentença trabalhista apenas o início de prova material na comprovação de tempo de serviço, fazendo-se necessária a produção de outras provas, conforme a redação do parágrafo $3^{\circ}$ do artigo 55 , da Lei $n^{\circ}$. 8.213/91.

Para alcançar o objetivo pretendido, será feita uma breve avaliação da Seguridade Social e das suas vertentes, as quais são a razão de existência da contribuição social, trazendo à luz a Previdência e seu caráter eminentemente contributivo por força da Emenda Constitucional n ${ }^{\circ}$.20/98.

Diante da necessidade de prévia contribuição, a questão da arrecadação, que é o mecanismo fundamental da manutenção da Seguridade Social e seu sistema, se mostra de extrema relevância, já que a finalidade da norma jurídica constitucional inserida no artigo 114 é o fortalecimento do custeio em razão dos 
possíveis efeitos previdenciários decorrentes do reconhecimento de fatos jurídicos trabalhistas.

Por fim, para que seja possível amarrar todas as ideias inseridas nos capítulos anteriores, será feita uma abordagem relativa à possibilidade de atribuição de outras competências ao magistrado trabalhista em razão da observância da reciprocidade contributiva e a efetiva execução de créditos tributários na Justiça do Trabalho.

Se a concessão de benefícios é a razão de ser da contribuição, uma vez reconhecidos os fatos jurídicos capazes de fazê-la incidir, bem como atingido o objetivo arrecadatório da execução de ofício com o adimplemento da obrigação tributária, não seria lógico imaginar que para o desencadeamento dos efeitos previdenciários fosse necessária passagem por novo processo judicial que reconheça os mesmos fatos para esse fim.

Essas questões fortalecerão a tese de incongruência dessa modalidade peculiar de execução de crédito tributário, na medida em que, diante do caráter retributivo do tributo, não poderia o legislador outorgar a competência para a execução do crédito sem conferir a mesma autonomia para o Juiz do Trabalho fizesse incidir também a norma de consequência dessa contribuição, a averbação de tempo e remuneração junto aos cadastros mantidos pelo INSS para a concessão de benefícios.

Não pode o trabalhador, parte mais fraca dessa relação, ser prejudicado pela conduta omissa do empregador no que pertine ao recolhimento da contribuição social tempestivamente $e$, muito menos, pela inércia da Administração Pública no seu poder/dever de fiscalização. Se os fatos passaram pelo crivo de um magistrado competente para promover, também, a arrecadação, o mesmo deverá gozar de jurisdição para determinar a incidência normativa previdenciária com a inclusão de dados nos registros do Cadastro Nacional de Informações Sociais. 


\section{EVOLUÇÃO HISTÓRICO-NORMATIVA}

Importante fazer uma breve análise evolutiva do ordenamento jurídico brasileiro para que seja possível identificarmos como os dispositivos legais que trataram do tema se transformaram ao longo do tempo até chegar à competência executiva que atualmente temos.

Não se pretende dar maior enfoque às questões de natureza histórica propriamente dita, mas sim ao modo como a norma jurídica se transformou ao longo dos anos para que fosse possível o atingimento da real intenção arrecadatória do fisco, que culminou com a fixação constitucional da competência sui generis da Justiça do Trabalho para a execução das contribuições sociais.

Apenas por questões didáticas e, principalmente, pragmáticas, o marco temporal a quo para o estudo evolutivo de nosso ordenamento será o início de vigência da Constituição de 1988, na medida em que foram as alterações trazidas por emendas constitucionais ao seu texto original que motivaram o estudo da competência executiva trabalhista.

No início de sua vigência, a Constituição trazia em seu artigo $114^{1}$ a delimitação da competência da Justiça do Trabalho, sem fazer qualquer alusão à possibilidade de execução da contribuição social decorrente do reconhecimento de fatos jurídicos trabalhistas que pudessem, também, resultar no dever de recolher o tributo destinado ao custeio da Seguridade Social.

Destaca-se aqui o fato de que, ao contrário do texto vigente, a redação original da Constituição previa um formato mais genérico de limitação da competência trabalhista, sem qualquer menção à execução das contribuições sociais.

Em relação à fase executiva, o texto original previa apenas a competência da Justiça do Trabalho para julgar os litígios decorrentes do cumprimento de suas próprias sentenças.

\footnotetext{
${ }^{1}$ Art. 114. Compete à Justiça do Trabalho conciliar e julgar os dissídios individuais e coletivos entre trabalhadores e empregadores, abrangidos os entes de direito público externo e da administração pública direta e indireta dos Municípios, do Distrito Federal, dos Estados e da União, e, na forma da lei, outras controvérsias decorrentes da relação de trabalho, bem como os litígios que tenham origem no cumprimento de suas próprias sentenças, inclusive coletivas.

$\S 1^{\circ}$ Frustrada a negociação coletiva, as partes poderão eleger árbitros.

$\S 2^{0}$ Recusando-se qualquer das partes à negociação ou à arbitragem, é facultado aos respectivos sindicatos ajuizar dissídio coletivo, podendo a Justiça do Trabalho estabelecer normas e condições, respeitadas as disposições convencionais e legais mínimas de proteção ao trabalho.
} 
Analisando superficialmente o dispositivo, poder-se-ia até cogitar dizer que a contribuição social seria uma das decorrências de um reconhecimento de vínculo no âmbito litigioso. Acontece que o direito é segmentado em disciplinas codificadas por instrumentos peculiares a cada uma delas e sem a menção expressa quanto à possibilidade de execução de contribuição social pela justiça do trabalho, forçosa a prevalência do entendimento de que, por se tratar de espécie de tributo, a contribuição social deveria ser discutida como tal, inclusive para fins executórios e de fixação de competência.

Em outras palavras, o texto original não pode ser interpretado extensivamente para abranger decorrências tributárias, penais ou administrativas, dentre outras, dos litígios trabalhistas resolvidos por sua justiça especializada. Da mesma forma que, em processo inverso, não se poderia conjeturar a possibilidade de execução no âmbito da Justiça Federal de efeitos trabalhistas decorrentes de uma fiscalização tributária nos recolhimentos previdenciários de determinada empresa, sendo necessária previsão constitucional expressa.

Assim, por razões óbvias de atingimento da ânsia arrecadatória do fisco, fez-se necessária, ao longo dos anos, a delimitação de formas e procedimentos para atribuir à Justiça do Trabalho autonomia fiscal e executória na arrecadação das contribuições previdenciárias decorrentes de sentenças trabalhistas por ela proferidas, as quais culminaram com a alteração do texto constitucional pela Emenda número 45 de 2004, que fez inserir o inciso VIII no artigo 114.

\subsection{Lei $\mathrm{n}^{\circ} \mathbf{7 . 7 8 7}$ de $\mathbf{3 0}$ de junho de $\mathbf{1 9 8 9}$}

Após o início da vigência da Constituição Federal, a primeira importante alteração normativa, no que se refere às contribuições sociais decorrentes de litígios na justiça do trabalho, se deu por meio da Lei no. 7.787/89, que trouxe modificações na legislação de custeio da Previdência Social vigente à época.

O artigo 12 do referido diploma legal previa que em caso de extinção de processos trabalhistas de qualquer natureza, inclusive a decorrente de acordo entre as partes, de que resultasse pagamento de vencimentos, remuneração, salário e outros ganhos habituais do trabalhador, o recolhimento das contribuições devidas à Previdência Social deveria ser efetuado in continenti. 
No parágrafo único, ainda, havia a menção expressa de que a autoridade judiciária deveria velar pelo fiel cumprimento do recolhimento, sem, contudo, atribuir-Ihe competência executória ou delimitar o procedimento e limitações de sua aplicabilidade.

Além do mais, é notória a ausência de qualquer consequência punitiva ou restritiva de direitos que o juiz da causa pudesse adotar no curso da execução trabalhista no caso de descumprimento pela parte devedora da determinação para recolhimento do tributo. Portanto, a falta de estipulação de pena pelo descumprimento da obrigação imposta, cumulada com a ausência de prazo para que isso ocorresse, levou ao entendimento de que o recolhimento das contribuições previdenciárias deveria ser efetuado "o mais rápido possível"2, em que pese a expressão in continenti conotar que o recolhimento deveria ser imediato, concomitante ao pagamento das demais verbas decorrentes do julgado trabalhista.

Diante da ausência de meios para concretização da imputabilidade normativa do dispositivo mencionado e visando garantir a livre atuação de seus magistrados, a Corregedoria Geral da Justiça do Trabalho, considerando que a lei dispunha sobre o recolhimento das contribuições devidas à Previdência Social, na hipótese de débitos trabalhistas reconhecidos em provimentos judiciais; que a citada lei atribui à autoridade judiciária o dever de zelar pelo fiel cumprimento dos recolhimentos; que a competência da Justiça do Trabalho tem regência constitucional; que os títulos judiciais prolatados pela Justiça do Trabalho versam sobre direitos exclusivamente trabalhistas; ainda que, constitucionalmente, cumpre à Justiça diversa o julgamento de controvérsias que envolvam matéria previdenciária; e a premissa de se presumir a compatibilidade da legislação ordinária com a Lei Básica - houve por bem editar em 20 de janeiro de 1990 o seu Provimento de $\mathrm{n}^{\circ} 1$.

Esse provimento, ademais, debelou questionamentos sobre a competência dos Juízes do Trabalho para executar contribuições previdenciárias e exigir o seu recolhimento, pois, além de deixar evidente que o julgamento de controvérsias envolvendo matéria previdenciária caberia à Justiça diversa (a Federal), estabeleceu que cópias dos comprovantes de recolhimento das

\footnotetext{
${ }^{2}$ MARTINS, Sérgio Pinto. Direito da seguridade social. 33. ed. São Paulo: Atlas, 2012, p. 249.
} 
contribuições previdenciárias fossem remetidas, com cópia da sentença prolatada, à Procuradoria do extinto Instituto de Administração Financeira da Previdência e Assistência Social (IAPAS), hoje Instituto Nacional do Seguro Social (INSS).

Cumpre destacar que, como bem observado por Sérgio Pinto Martins ${ }^{3}$, a ideia inicial de quem deu subsídios à edição do artigo 12 da Lei $n^{\circ} 7.787 / 89$ era de que houvesse um fiscal do trabalho em cada Junta de Conciliação e Julgamento, o qual teria a competência para fiscalizar o recolhimento das contribuições sociais decorrentes dos litígios trabalhistas resolvidos pela justiça especializada e tomar as providências que assegurassem a arrecadação. Entretanto, essa prática jamais se tornou realidade em razão da falta de fiscais para esse fim e por estes não compreenderem os mecanismos do processo trabalhista.

Assim, diante da incompetência arrecadatória do juiz do trabalho, o dispositivo em comento acabou se tornado mais uma orientação de colaboração e informação, do que propriamente uma delegação de competência, até pelo fato de que isso seria inconstitucional perante a existência de Justiça diversa a quem competia a execução de tributos federais nos termos do artigo 109 da Constituição.

Nesse mesmo diapasão, Odonel Urbano Gonçalves ${ }^{4}$ assevera que não seria atribuição do juiz do trabalho a verificação da correção do recolhimento da contribuição social, muito menos a sua execução, na medida em que era necessária a atividade fiscalizatória do INSS para constituir o crédito e, no caso de inadimplemento, executá-lo perante a justiça competente, a Federal.

\footnotetext{
${ }^{3}$ MARTINS, Sérgio Pinto. Execução da contribuição previdenciária na justiça do trabalho. 3 . ed. São Paulo: Atlas, 2008, p. 2.

4 "Não é atribuição do Juiz do Trabalho verificar a correção do recolhimento; esta função cabe ao órgão competente do Instituto Nacional do Seguro Social (...) A atividade do Juiz do Trabalho, no caso, há que se cingir à notificação da entidade autárquica (INSS), para as providências administrativas cabíveis. Constituído o crédito previdenciário, nos moldes do disposto no artigo 45, emergirá para o órgão do Seguro Social (INSS) o direito de ação para a respectiva cobrança. A competência para dirimir o litígio é da Justiça Federal. Isto porque se tratará de ação de cobrança de contribuição previdenciária, ocupando o pólo ativo uma autarquia federal (INSS)." (Cf. GONÇALVES, Odonel Urbano. Seguridade Social Comentada. São Paulo, LTr., 1997, p. 55. ENESES, Geraldo Magela e Silva. Competência da Justiça do Trabalho Ampliada em Face da EC n. 20/98. In Revista LTr. São Paulo, v. 63, n. 2, fev., 1999, p. 171.)
} 


\subsection{Lei $\mathbf{n}^{\circ} 8.212$ de 24 de julho de 1991}

Com o advento do novo Plano de Previdência Social, o artigo 43 da Lei $n^{\circ}$ $8.212 / 91^{5}$ em sua redação original, por sua vez, revogou tacitamente o artigo 12 da Lei $n^{0}$ 7.789/89, trazendo a previsão de que no caso de extinção dos processos trabalhistas de que resultar pagamento de remuneração ao segurado, o recolhimento das contribuições devidas à Seguridade Social seria efetuado incontinenti.

Em complementação, o artigo 44 do mesmo diploma legal trazia a determinação para que a autoridade judiciária exigisse a comprovação do fiel cumprimento do recolhimento das contribuições sociais decorrentes das decisões da Justiça do Trabalho.

Na prática, não houve nenhuma alteração relevante relacionada ao texto da Lei $n^{\circ} 7.787 / 89$, principalmente em relação à sua imputabilidade normativa. Razão pela qual, pouco tempo depois, a Lei $n^{\circ} 8.212 / 91$ foi alterada pela Lei $n$ ํ 8.620/93, que estabeleceu nova redação aos dispositivos acima mencionados.

$\mathrm{O}$ artigo 43 passou a ter a seguinte redação:

Art. 43. Nas ações trabalhistas de que resultar o pagamento de direitos sujeitos à incidência de contribuição previdenciária, o juiz, sob pena de responsabilidade, determinará o imediato recolhimento das importâncias devidas à Seguridade Social.

O referido dispositivo, ainda, passou a ter um parágrafo único, que determinava que "nas sentenças judiciais ou nos acordos homologados em que não figurarem, discriminadamente, as parcelas legais relativas à contribuição previdenciária, esta incidirá sobre o valor total apurado em liquidação de sentença ou sobre o valor do acordo homologado".

O artigo 44 continuou praticamente com a mesma redação, ressalvado que para velar pelo fiel cumprimento do artigo 43, a autoridade judiciária deveria agora expedir notificação ao Instituto Nacional do Seguro Social - INSS, para dar ciência dos termos da sentença ou do acordo celebrado, e não mais à Procuradoria da Fazenda Nacional, conforme sua redação anterior.

\footnotetext{
5 "em caso de extinção de processos trabalhistas de qualquer natureza, inclusive a decorrente de acordo entre as partes, de que resultar pagamento de remuneração ao segurado, o recolhimento das contribuições devidas à Seguridade Social será efetuado incontinenti”.
} 
Entretanto, não houve uma mudança brusca em relação ao cumprimento da determinação judicial, uma vez que, na omissão do responsável pelo recolhimento da contribuição previdenciária, o Juiz do Trabalho não gozava de qualquer poder sancionatório, cabendo a ele apenas notificar o INSS, o qual poderia tomar as medidas administrativas vinculadas e a inscrição da dívida ativa, para fazer a cobrança judicial perante a Justiça Federal.

Portanto, como bem observado por Wladimir Novaes Martinez ${ }^{6}$, juiz do Trabalho, foi, na verdade, transformado em verdadeiro órgão auxiliar do INSS, pois não gozava de qualquer competência sancionatória visando à arrecadação. A sua atuação encerrava-se com a informação do INSS em relação ao não recolhimento ou quando havia dúvida quanto a sua regularidade.

Acontece que, o artigo 43 trazia em sua nova redação a pena de responsabilidade para o juiz que não determinasse o imediato recolhimento das contribuições sociais, o que acabou por criar grande agitação na magistratura do trabalho. Primeiro, em razão de não haver a menção expressa da pena à que estaria sujeito o juiz que descumprisse a norma.

Depois, porque não era de competência do Juiz do trabalho definir alíquotas, bases de cálculo e forma de atualização dos valores das contribuições sociais decorrentes de suas decisões. Desse modo, como estabelecer ou verificar se a quantia devida foi realmente recolhida pelo responsável tributário para fins de eventual notificação do INSS?

$\mathrm{Na}$ tentativa de contornar o estado de incerteza que assolava a comunidade trabalhista à época e já demonstrada a real natureza arrecadatória das alterações normativas que vinham acontecendo, a Corregedoria do Tribunal Superior do Trabalho (TST) editou o Provimento ํㅡ 2/93, o qual dispôs acerca do procedimento a ser observado no âmbito da execução trabalhista, no que diz respeito à incidência e ao recolhimento de contribuições devidas à Previdência Social sobre pagamento de direitos nas ações ajuizadas na Justiça do Trabalho.

Dentre outras providências, o referido Provimento estabeleceu a obrigatoriedade do recolhimento de contribuição sobre parcelas de natureza remuneratória resultantes de sentenças condenatórias e homologatórias de conciliação, ainda que não quantificadas, bem como que ausente a comprovação

\footnotetext{
${ }^{6}$ MARTINEZ, Wladimir Novaes. Comentários à Lei Básica da Previdência Social. São Paulo: LTr, 1996, p. 458.
} 
do recolhimento ou havendo dúvida sobre sua exatidão, o Diretor da Secretaria deveria encaminhar ao órgão previdenciário informações sobre o número e identificação das partes, e o processo ficaria por trinta dias em Secretaria à disposição do fiscal de contribuições previdenciárias para exame e coleta de dados para levantamento do termo de verificação de débito.

Seguindo essa linha, fica claro que, em que pese não ser expressa a competência para a execução, pretendia-se, por meio dessas inúmeras adequações infraconstitucionais, imputar à Justiça do Trabalho o ônus de calcular, deduzir e recolher as contribuições sociais decorrentes de seus julgados.

Isso fica ainda mais notório com a baixa do Provimento no 1/96 pela Corregedoria do $\mathrm{TST}^{7}$, o qual deixou clara a atribuição do juiz da execução quanto à determinação de medidas para o cálculo, dedução e recolhimento das contribuições devidas pelo empregado ao Instituto Nacional de Seguro Social, em razão de parcelas que the vierem a ser pagas por força de decisão proferida em reclamação trabalhista (artigo $3^{\circ}$ ).

Analisando o referido dispositivo, podemos afirmar, sem medo de errar, que o magistrado trabalhista, como verdadeiro assistente do fisco, deveria analisar de forma pormenorizada as contribuições sociais decorrentes de suas decisões e lançar mão de procedimentos eficazes para fins de cálculo e recolhimento destas. Adotadas essas providências, no caso de omissão da parte responsável pelo recolhimento ou dúvida quanto à sua regularidade, cabia ao magistrado o dever de informação ao INSS, para que este pudesse adotar as medidas jurídicas competentes para a arrecadação do crédito tributário decorrente das decisões proferidas na esfera trabalhista.

De toda sorte, mesmo não intervindo na execução propriamente dita do crédito de natureza tributária, o juiz do trabalho acabava acumulando competências incompatíveis com a sua jurisdição, tal qual o processamento dos

\footnotetext{
7 "Art. 3ํ- Compete ao juiz da execução determinar as medidas necessárias ao cálculo, dedução e recolhimento das Contribuições devidas pelo empregado ao Instituto Nacional de Seguro Social, em razão de parcelas que the vierem a ser pagas por força de decisão proferida em reclamação trabalhista (art. 43 da Lei no 8212/1991, com a redação dada pela Lei no 8620/1993).

$\S 1$ ํ Homologado o acordo ou o cálculo de liquidação, o juiz determinará a intimação do executado para comprovar, nos autos, haver feito o recolhimento dos valores devidos pelo empregado à Previdência Social.

$\S 2$ ․ Havendo pagamento de parcelas de direitos trabalhistas, não comprovado o recolhimento previsto no $\S 1^{\circ}$, o juiz dará imediata ciência ao representante do Instituto Nacional de Seguridade Social, determinando a remessa mensal do rol dos inadimplentes, procedendo da mesma maneira em caso de alienação de bens em execução de sentença."
} 
cálculos do tributo, a expedição de providências para sua quitação e fiscalização do correto recolhimento, atividades estranhas à alçada trabalhista.

Essas alterações trazidas pelas reformas legislativas e pelos provimentos baixados pelo TST acabaram por acirrar ainda mais os ânimos dos juristas que se dedicavam ao direito do trabalho, uma vez que parecia se pretender, por meio de instrumentos infraconstitucionais, empurrar à força a competência executiva da Justiça do Trabalho em relação aos créditos previdenciários decorrentes de suas decisões. Alguns, como João Oreste Dalazen ${ }^{8}$, adotavam o discurso legalista, porém realista, no sentido de que a lei outorgava ao INSS as mesmas prerrogativas da Fazenda Nacional, pelo que seria de sua incumbência a arrecadação, fiscalização, lançamento e normatização do recolhimento das contribuições sociais. Além do mais, a própria Lei $n^{\circ} 8.212 / 91$, em sua redação vigente à época, previa apenas que 0 juiz do trabalho deveria determinar 0 recolhimento das contribuições, não lhe competindo qualquer outra atribuição extra, que também não poderia ser objeto de Provimento do TST, sob pena de desrespeitar a hierarquia das leis.

Lançar mão de uma colaboração por parte da magistratura trabalhista pela informação dos casos que pudessem dar origem ao recolhimento de tributo é muito diferente do que se pretendia com as inúmeras alterações normativas até aquele momento, pois determinar o recolhimento, calcular o tributo e fiscalizar a arrecadação são atividades que demandam não só conhecimento técnico específico, como também competência jurisdicional que a Constituição não outorgava à Justiça do Trabalho em sua redação original.

\footnotetext{
8 "Primeiro, porque a própria lei reza que ao INSS incumbe 'arrecadar, fiscalizar, lançar e normatizar o recolhimento das contribuições sociais', promovendo a cobrança executiva em juízo 'com as mesmas prerrogativas e privilégios da Fazenda Nacional' (arts. 33 e 39, parágrafo 10, da Lei $n^{\circ}$ 8212/91). Por conseguinte, tratando-se de autarquia federal, a competência é da Justiça Federal, em razão da pessoa (CF/88, art. 109, I). (...) Segundo, porque a Lei $n^{\circ} 8.212 / 91$, como visto, não contempla norma de competência material da JT: fixou unicamente um dever aos seus órgãos. E o dever consiste apenas em determinar o recolhimento, o que é coisa muito diversa de executar por dívida previdenciária." (DALAZEN, João Oreste. Competência material da Justiça do Trabalho. São Paulo: Editora LTr. 1994, p. 151-152).
} 


\subsection{Emenda Constitucional $\mathrm{n}^{\circ} 20$ de 15 de dezembro de 1998}

Foi nesse contexto de incertezas que o Congresso Nacional, por meio da Emenda Constitucional $n^{\circ}$ 20/98, resolveu inserir de vez no corpo da Constituição a competência da Justiça do Trabalho para executar, de ofício, as contribuições sociais previstas no artigo 195, I, 'a', e II, e seus acréscimos legais, decorrentes das sentenças que proferir.

Cumpre-se destacar que, diante da nova redação do artigo 114 da Constituição, não há mais o que se discutir quanto à possibilidade de se processar em jurisdição estranha matéria de natureza tributária. A redação do incluído parágrafo $3^{\circ}$ é cristalina e não dá mais margem para contendas de ordem pragmática quanto à competência do juiz do trabalho para executar as contribuições sociais decorrentes de suas decisões ${ }^{9}$.

Nesse momento é importante ressalvar que, ainda que não se possa discutir, no campo da competência constitucional, a possibilidade de se processar a execução tributária em solo trabalhista, não nos afasta a possibilidade de argumentar do ponto de vista dogmático algumas inconsistências que se mostram patentes no momento da incidência normativa, principalmente, quando estamos falando de processo e procedimento.

Feito esse breve comentário, pertinente à consideração feita por Sérgio Pinto Martins ${ }^{10}$ quanto à real intenção da inserção do parágrafo $3^{\circ}$ ao artigo 114 da Constituição. Na verdade o objetivo foi buscar efetivação no recolhimento das contribuições sociais incidentes sobre as decisões proferidas em âmbito trabalhista, inclusive essa intenção restou expressa na exposição de motivos do Deputado Régis de Oliveira, para a proposta de Emenda Substitutiva 54 à Comissão Especial da Câmara dos Deputados.

Portanto, conforme já havíamos tratado antes, a razão de ser das alterações normativas relativas à miscigenação das questões tributárias e trabalhistas sempre foi a maior arrecadação. De modo que, do ponto de vista da eficiência e praticidade, nada melhor do que criar mecanismos jurídicos que

\footnotetext{
9 " $\$ 3^{\circ}$ Compete ainda à Justiça do Trabalho executar, de ofício, as contribuições sociais previstas no art. 195, I, a, e II, e seus acréscimos legais, decorrentes das sentenças que proferir." (Incluído pela Emenda Constitucional oㅜ 20, de 1998).

${ }^{10}$ MARTINS, Sérgio Pinto. Execução da contribuição previdenciária na justiça do trabalho. 3. ed. São Paulo: Atlas, 2008, p. 4.
} 
possibilitem não só a constatação do crédito em jurisdição sui generis, como também a própria execução do tributo na fonte que o originou.

Nesse contexto, para sanar o déficit de agentes públicos que pudessem, por competência do cargo, fiscalizar, arrecadar e promover a execução em ambiente próprio dos tributos decorrentes de decisões da Justiça do Trabalho, optou-se por transformar, por emenda constitucional, o Juiz do Trabalho em agente fiscalizador e a sua justiça em órgão de execução.

Havia, assim, um interesse político por trás das recorrentes alterações normativas visando atribuir competência arrecadatória de tributo ao juiz do trabalho. Na lição de Rodrigues Pinto ${ }^{11}$, embasado por outros autores, a intenção do legislador foi transformar a Justiça do Trabalho em mais um órgão de arrecadação, o que já era manifestado desde a edição da Lei $n^{\circ} 8.620 / 93$, que atribuiu "pena de responsabilidade" para o juiz que não velasse pelo fiel recolhimento das contribuições sociais. Na opinião do autor, o cumprimento dessa delegação de competência representaria desgaste e desprestígio da magistratura trabalhista.

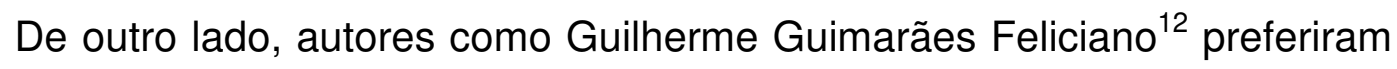
enxergar o lado positivo da Emenda $n^{\circ}$ 20/98, uma vez que à época de sua edição a Justiça do Trabalho vivia um momento de depreciação e a dilatação de competência acabou por inflar a autoestima da magistratura trabalhista que passou a enfrentar menos problemas no que pertine, por exemplo, a discriminação de verbas e a resistência dos fiscais do INSS, que agora têm a sua atuação funcional submetida ao crivo do juiz do trabalho, pelo menos em relação às contribuições decorrentes de seus julgados.

Sob uma ótica sociopolítica, não se vislumbra maior valimento à Justiça do Trabalho em razão da extensão de competência. Talvez, levando-se em consideração o cenário da época, quando era ainda uma Justiça menos respeitada em razão de sua atuação especializada, o fato de passar a tratar de tema antes exclusivo da Justiça Federal tenha servido de instrumento ou bandeira para melhorar a sua imagem perante outros Órgãos do Poder Judiciário.

11 RODRIGUES PINTO, José Augusto. Os Graves Embaraços Processuais da Emenda Constitucional n. 20/98, in Revista Ltr, São Paulo, Ltr, n. 63-05/599-609, p. 600-601.

${ }_{12}$ FELICIANO, Guilherme Guimarães. Execução das contribuições sociais na justiça do trabalho. São Paulo: LTr, 2002, p. 30-32. 
Muito se discutiu em relação à autoaplicabilidade da norma constitucional inserida pela Emenda $n^{\circ} 20$ no parágrafo $3^{\circ}$ do artigo 114 da Constituição, na medida em que ainda pairavam dúvidas procedimentais quanto à forma em que se daria a execução das contribuições sociais na Justiça do Trabalho e a legislação infraconstitucional aplicável para esse fim.

Importante estabelecermos qual era o enquadramento constitucional do parágrafo $3^{\circ}$ do artigo 114 da Constituição Federal em 1998, quando foi inserido no mundo jurídico. De acordo com o ensinamento de José Afonso da Silva ${ }^{13}$, as normas constitucionais podem ser divididas em três grupos: 1) as de eficácia plena; 2) as de eficácia contida; e 3) as de eficácia limitada.

As normas constitucionais de plena eficácia são aquelas que produzem em si a plenitude dos seus efeitos, portanto, não dependem de norma infraconstitucional de complementação. São revestidas de todos os elementos necessários à sua executoriedade, tornando possível sua aplicação de maneira direta, imediata e integral. As de eficácia limitada não produzem a plenitude de seus efeitos, dependendo da integração por meio de lei. Não contêm os elementos necessários para sua executoriedade, assim enquanto não forem complementadas pelo legislador, a sua aplicabilidade é mediata, mas depois de complementadas tornam-se de eficácia plena.

Já as normas de eficácia contida produzem a plenitude dos seus efeitos, entretanto, podem ter o seu alcance limitado. Assim, podemos dizer que essas normas têm eficácia plena até que sobrevenha a restrição, seja em razão da existência na própria norma de uma cláusula expressa de redutibilidade ou em razão dos princípios da proporcionalidade e razoabilidade.

Em relação ao parágrafo $3^{\circ}$ do artigo 114 da Constituição, inserido por força da Emenda $n^{\circ}$ 20/98, por se tratar de regra de fixação de competência, parece-nos claro se tratar de norma de plena eficácia, portanto, autoaplicável do ponto de vista formal.

$\mathrm{Na}$ mesma linha, o entendimento de Rodrigues Pinto ${ }^{14}$ que assim ponderou:

a norma que (...) repartiu entre juiz federal stricto sensu e o juiz do Trabalho a competência material para a execução forçada das contribuições devidas pela

\footnotetext{
13 SILVA, José Afonso. Aplicabilidade das normas constitucionais. $3^{\text {a }}$ ed. São Paulo: Malheiros, 1999, p. 82-83.

${ }^{14}$ Op. cit., p.608.
} 
empresa ao INSS é autoaplicável, como todas as que dispõem sobre a determinação de competência, porém, depende profundamente de adequada estrutura normativa de processo que Ihe garanta efetividade prática.

As incertezas quanto aos aspectos processuais de aplicação da nova regra de competência material da Justiça do Trabalho não afastam o fato de que a norma constitucional em questão não depende de outra norma que a complemente para que goze de eficácia. A competência está definida, sendo possível a sua aplicação direta, imediata e integral, e é, inclusive, a conclusão de Pereira de Castro e Lazzari ${ }^{15}$.

Ademais, bem asseverou Rodrigues $\mathrm{Pinto}^{16}$ que as regras ordinárias de direito material e processual não devem interferir na eficácia plena da norma de determinação de competência material do juiz, pelo menos no que diz respeito à sua aptidão para o exercício do poder em relação à matéria, pessoas e processo que determina.

A discussão passou a girar, portanto, em torno da Lei aplicável em razão da competência jurisdicional do magistrado trabalhista para a execução das contribuições sociais decorrentes de suas decisões e não mais em relação à eficácia do parágrafo $3^{\circ}$ do artigo 114 da Constituição. Existiam, à época, três correntes, a primeira e majoritária acreditava que a Consolidação das Leis do Trabalho (CLT) deveria ser aplicada no processo de execução tributária em âmbito de jurisdição trabalhista, sendo as omissões integradas supletivamente pela Lei $n^{\circ} 6.830 / 80$, que dispõe sobre a cobrança judicial da Dívida Ativa da Fazenda Pública, e pelo Código de Processo Civil, nos termos do artigo 889 da CLT.

A segunda corrente defendia a aplicação da Lei $n^{\circ} 6.830 / 80$, pelo fato de que, nos dizeres de Geraldo Magela e Silva Meneses ${ }^{17}$, "já existe no ordenamento positivo norma legal que rege a execução fiscal". Na mesma estreita, podemos dar força à aplicação da Lei $n^{\circ} 6.830 / 80$, citando o artigo $2^{\circ}$ da própria lei, que

15 "O $\S 3^{\circ}$ do art. 114 da Constituição, criado pela Emenda Constitucional n. 20/98, tem aplicabilidade imediata a todas as ações em curso perante a Justiça do Trabalho." (PEREIRA DE CASTRO, Carlos Alberto, \& LAZZARI, João Batista. Contribuição à seguridade social em razão das decisões proferidas pela Justiça do Trabalho e sua execução, in Revista LTr, São Paulo, LTr, n. 63-02/173-182, p. 181).

${ }^{16}$ Op. cit., p. 601.

${ }^{17}$ MENESES, Geraldo Magela e Silva. Competência da Justiça do Trabalho Ampliada em Face da EC n 20/98. Revista LTr, São Paulo, n. 63-2/170, fev. 1999. 
estabelece a sua aplicação seja para a cobrança de débitos de natureza tributária ou não, o que facilitaria a sua aplicação em ambiente trabalhista. Esta foi, inclusive, a conclusão de Carlos Alberto Pereira de Castro e João Batista Lazzari $^{18}$.

O grande problema dessa corrente é lidar com o fato de que, em que pese se tratar de crédito tributário, a contribuição social decorrente dos julgados proferidos na Justiça do Trabalho é constituída para fins executivos sem lançamento ou inscrição por autoridade competente em Dívida Ativa.

Como explicar, então, a aplicação da Lei $n^{\circ} 6.830 / 80$, em que esta prescinde a existência de um lançamento tributário nos moldes do artigo $142 \mathrm{e}$ seguintes do Código Tributário Nacional (CTN), a inércia do contribuinte no prazo fixado e a consequente inscrição pela repartição competente na Dívida Ativa, conforme previsão do artigo 201, também, do CTN?

A terceira corrente entendia pela aplicação do Código de Processo Civil por subsidiariedade, uma vez que a CLT seria aplicável tão somente para a execução dos créditos de natureza trabalhista, sem qualquer menção às contribuições decorrentes das decisões proferidas pela Justiça do Trabalho e, para a aplicação da Lei $n^{\circ} 6.830 / 80$, dependia-se da inscrição do crédito tributário em dívida ativa, o que se mostrava impossível diante da forma como este era constituído.

O cenário à época era de muita dúvida, principalmente em relação à metodologia que deveria ser utilizada na execução de ofício do crédito de natureza estranha à trabalhista. Seria necessária a prévia inscrição na Dívida Ativa? Qual o prazo para citação, garantia de bens e embargos à execução? A norma constitucional gozava de eficácia plena, mas dependia de mais esclarecimentos procedimentais para que fosse possível colocá-la em prática.

\subsection{Lei $\mathrm{n}^{\circ} \mathbf{1 0 . 0 3 5}$ de $\mathbf{2 5}$ de outubro de $\mathbf{2 0 0 0}$}

Podemos afirmar, então, que as alterações na Consolidação das Leis do Trabalho - CLT trazidas pela Lei $n^{\circ} 10.035 / 00$, para estabelecer os procedimentos de execução das contribuições devidas à Previdência Social no âmbito da Justiça do Trabalho após o início de vigência da Emenda Constitucional

${ }^{18}$ Op. cit., p. 179. 
$n^{\circ} 20 / 98$, foram as mais importantes no âmbito infraconstitucional no que pertine ao início de fato e de direito da possibilidade de arrecadação por via transversa dos tributos decorrentes dos julgados trabalhistas.

Afinal, mesmo persistindo a possibilidade de suscitação de vícios dogmáticos na escolha, a Lei estabeleceu definitivamente a norma a ser aplicada para a execução da contribuição previdenciária na Justiça do Trabalho. Em outras palavras, finalmente deu-se vida ao processo de execução tributária fora da Justiça Federal, o qual seguiria regramento próprio e distinto do que era aplicado naquela.

Passaremos a analisar os dispositivos inseridos e alterados no corpo da CLT com o intuito de entender a pertinência e importância de cada um deles do ponto de vista pragmático, visto que diante da nova competência atribuída à Justiça do Trabalho por força da Emenda Constitucional, forçoso compreender como isso se aplicaria no dia a dia.

A primeira alteração trazida pela Lei $n^{0} 10.035 / 00$ no corpo da CLT foi a inserção do parágrafo único ao artigo 831 da $\mathrm{CLT}^{19}$, que ratificou a natureza de decisão irrecorrível do acordo firmado entre as partes e lavrado em termo de audiência. A irrecorribilidade, no entanto, limita-se às partes, na medida em que a Previdência Social pode se ver prejudicada pelo teor do documento.

Como defendido por Guilherme Guimarães Feliciano ${ }^{20}$, a relativização dos efeitos do termo de conciliação lavrado em audiência decorrente da alteração trazida pela Lei $n^{\circ} 10.035 / 00$ gerou um abalo histórico com a possibilidade de recurso por parte do INSS. Até então, a irrecorribilidade dos termos de conciliação era tida em termos absolutos no parágrafo único do artigo 831 da CLT, se tratando de aspecto peculiar do processo trabalhista e sem paradigma no processo civil (cf. artigos 269, II e III, e 505 CPC).

A irrecorribilidade das transações decorre dos princípios da celeridade processual e da proteção que inspiram o direito material do trabalho. A intenção era dar eficácia imediata às transações lavradas em juízo, aderindo à proposta conciliatória e abdicando, de certa forma, do litígio, características presentes no âmbito da Justiça do Trabalho. Com a alteração, o efeito processual de coisa

19 "Parágrafo único. No caso de conciliação, o termo que for lavrado valerá como decisão irrecorrível, salvo para a Previdência Social quanto às contribuições que Ihe forem devidas." (NR)

${ }_{20}$ FELICIANO, Guilherme Guimarães. Execução das contribuições sociais na justiça do trabalho. São Paulo: LTr, 2002, p. 67. 
julgada formal do termo conciliatório alcança apenas as partes da ação em total observância da norma contida no artigo 472 do CPC.

Cumpre-se destacar que a alteração não criou direito novo em favor do INSS, mas inovou a forma como se operaria a discussão quanto ao fato gerador, base de cálculo e alíquota da contribuição social. Antes, a autarquia previdenciária deveria discutir seu eventual inconformismo com o termo lavrado por meio de ação autônoma de impugnação e agora a contenda se trava em sede de recurso inominado.

O artigo 832 da CLT prevê a necessidade de constar o nome das partes, o resumo do pedido e da defesa, a apreciação das provas, os fundamentos da decisão e a respectiva conclusão para que as decisões proferidas pela Justiça do Trabalho gozem de eficácia. Diante da ampliação de competência material decorrente da Emenda Constitucional $n^{\circ}$ 20/98, resultou a obrigatoriedade de indicação da natureza jurídica das parcelas constantes das condenações ou dos acordos homologados, inclusive o limite de responsabilidade de cada parte pelo recolhimento da contribuição previdenciária.

A inserção do parágrafo $3^{\circ}$ ao artigo 832 da $\mathrm{CLT}^{21}$ tem natureza claramente fiscalizatória, uma vez que o magistrado deverá demonstrar claramente as verbas decorrentes de suas decisões e, especialmente, àquelas constantes de acordos firmados entre as partes e no curso da ação trabalhista. Não é incomum a homologação de acordo por juiz do trabalho no qual o vínculo empregatício é ponto incontroverso e a parcela pecuniária decorrente da transação é declarada cem por cento indenizatória e, portanto, isenta de recolhimentos previdenciários. Isso pode gerar dúvida ou até mesmo discordância por parte do INSS.

Por essa razão, foi necessário também inserir no texto da CLT, no parágrafo $4^{\circ}$ do artigo $832^{22}$, a determinação para que o INSS fosse intimado das decisões homologatórias de acordos nas quais exista a previsão de parcela indenizatória. E mais, no caso de discordância, ficou-lhe facultado a oportunidade

\footnotetext{
21 "§ 3o As decisões cognitivas ou homologatórias deverão sempre indicar a natureza jurídica das parcelas constantes da condenação ou do acordo homologado, inclusive o limite de responsabilidade de cada parte pelo recolhimento da contribuição previdenciária, se for o caso."

22 "§ 40 O INSS será intimado, por via postal, das decisões homologatórias de acordos que contenham parcela indenizatória, sendo-lhe facultado interpor recurso relativo às contribuições que the forem devidas."
} 
para interposição de recurso, cuja temática é limitada à discussão das contribuições devidas à autarquia previdenciária.

Nos dizeres de Guilherme Guimarães Feliciano ${ }^{23}$ :

Voltou à carga do legislador, reproduzindo a ideia na Lei n. 10.035/2000 e inserindo-a, dessa feita, na própria Consolidação das Leis do Trabalho, mais afeta ao dia-a-dia do magistrado trabalhista. Inova-se, porém, no procedimento e na sua natureza: consoante exegese corrente do art. 44 da Lei n. 8.212/91, notificava-se o INSS mediante ofício, para que providenciasse o que de direito nas instâncias próprias; agora, notifica-se-o mediante intimação postal para que se manifeste nos autos; e intimação, sabe-se, é "o ato pelo qual se dá ciência a alguém dos atos e termos do processo, para que faça ou deixe de fazer alguma coisa" (art. 234 do CPC), sob pena de preclusão.

O referido dispositivo limita-se à intimação das decisões homologatórias de acordos, exatamente as que raramente ensejavam, na prática jurídica, a providência do artigo 44 da Lei $\mathrm{n}^{0}$ 8.212/91.

Cumpre-se destacar que as alterações supramencionadas tinham por objetivo a outorga de eficácia previdenciária e fiscal para as decisões proferidas no processo trabalhista, bem como forçar a sua eventual discussão, em razão de inconformismo por parte do INSS, dentro do processo que originou o crédito decorrente da natureza dos títulos correspondentes às parcelas constantes da condenação ou do acordo homologado.

Observou Guilherme Guimarães Feliciano ${ }^{24}$ que a Lei $\mathrm{n}^{\circ} 10.035 / 00$, ao acrescer à $\operatorname{CLT}$ o parágrafo $4^{\circ}$ do artigo 831, não esclareceu questões de competência, prazo e procedimento relativos ao tal recurso de legitimidade ativa do INSS, muito menos os efeitos que sua eventual interposição desencadearia. Dessa forma, coube ao intérprete extraí-los do sistema recursal vigente para dar eficácia à norma.

No campo da execução propriamente dito, foi acrescido o parágrafo único ao artigo 876 da CLT, posteriormente alterado pela Lei $n^{\circ} 11.457 / 07$, mas que em suma traz a previsão expressa de que deveriam ser executadas ex officio as contribuições sociais (créditos previdenciários) devidas em decorrência de decisão proferida pelos Juízes e Tribunais do Trabalho, resultantes de

${ }^{23}$ Op. cit., p. 79.

${ }^{24}$ Op. cit., p. 81. 
condenação ou homologação de acordo, inclusive sobre os salários pagos durante o período contratual reconhecido.

O caput do artigo 876 deixa claro que a execução das contribuições sociais seria processada em caráter acessório aos das decisões passadas em julgado ou das quais não tenha havido recurso com efeito suspensivo dos acordos, quando não cumpridos, dos termos de ajuste de conduta firmados perante o Ministério Público do Trabalho e dos termos de conciliação firmados perante as Comissões de Conciliação Prévia ${ }^{25}$.

A norma jurídica inserida no artigo 876 da CLT apenas trouxe para o âmbito infraconstitucional a disposição do então parágrafo $3^{\circ}$ do artigo 114 da Constituição, o qual fora inserido pela Emenda $n^{\circ} 20 / 98$. Foi atribuída a dimensão e campo de aplicabilidade da competência de execução ampliada pelo dispositivo constitucional, sendo apenas os créditos tributários resultantes de condenação ou homologação de acordo, perante a Justiça do Trabalho, é que deveriam ser executados de ofício por essa Justiça especializada.

Sérgio Pinto Martins ${ }^{26}$ ponderou o fato de que a Lei $n^{\circ} 10.035 / 00$, ao inserir o parágrafo único no artigo 876 da CLT, acabou por limitar a abrangência da competência executória em descompasso com o texto constitucional. $\mathrm{Na}$ verdade, o artigo 114 da Constituição não exige que a sentença seja condenatória ou homologatória, bastando haver sido proferida pela Justiça do Trabalho. Já o dispositivo da CLT traz a especificação de que as decisões deverão ser de condenação ou homologação de acordo.

Dessa feita, as decisões meramente declaratórias, em que haja tão somente o reconhecimento de vínculo empregatício sem a condenação pecuniária, acabam por não produzir os efeitos previdenciários que dela se espera, posto que, na prática, não localizado o recolhimento ao empregado é sonegado o direito de computo do período.

\footnotetext{
25 "Art. 876 - As decisões passadas em julgado ou das quais não tenha havido recurso com efeito suspensivo; os acordos, quando não cumpridos; os termos de ajuste de conduta firmados perante o Ministério Público do Trabalho e os termos de conciliação firmados perante as Comissões de Conciliação Prévia serão executados pela forma estabelecida neste Capítulo." (Redação dada pela Lei no 9.958, de 12/1/2000).

"Parágrafo único. Serão executadas ex officio as contribuições sociais devidas em decorrência de decisão proferida pelos Juízes e Tribunais do Trabalho, resultantes de condenação ou homologação de acordo, inclusive sobre os salários pagos durante o período contratual reconhecido." (Redação dada pela Lei oํ 11.457, de 2007).

${ }^{26}$ MARTINS, Sérgio Pinto. Comentários à CLT. 10ª ed. São Paulo: Atlas, 2013, p. 958.
} 
Cumpre-se destacar que o Supremo Tribunal Federal (STF) ${ }^{27}$ entende que apenas as contribuições sociais decorrentes de decisão condenatória podem ser objeto de execução de ofício pela Justiça do Trabalho.

O artigo 878-A foi acrescido para facultar ao devedor o pagamento espontâneo da parte que entender devida à Previdência Social, entretanto, sem afastar a possibilidade de o juiz da causa dar início na execução ex officio de eventuais diferenças encontradas na apuração do recolhimento efetuado imediatamente ${ }^{28}$.

Foi incluída a previsão de que na liquidação de sentença nos moldes do artigo 879 da CLT, abrangeria, também, o cálculo das contribuições sociais, o que mais uma vez evidencia a acessoriedade da execução ex officio, bem como a necessidade das partes serem intimadas para apresentarem seus cálculos, nos quais devem incluir as contribuições incidentes sobre as verbas trabalhistas reconhecidas em eventual condenação (parágrafos $1^{\circ}$-A e $1^{\circ}$-B).

O parágrafo $3^{\circ}$, inserido ao referido dispositivo da CLT trouxe a previsão de intimação do INSS para manifestar-se no prazo de dez dias, sob pena de preclusão, sobre os cálculos apresentados pela parte ou pelos órgãos auxiliares da Justiça. A metodologia de cálculo na atualização dos créditos devidos à Previdência Social permaneceu observando a legislação específica (artigo 879, parágrafo $\left.4^{\circ}, \mathrm{CLT}\right)$.

Iniciada a execução, nos termos do artigo 880 da CLT, alterado pela Lei $n^{\circ} 10.035 / 00$ e, posteriormente, pela Lei $n^{\circ} 7.305 / 07$, o juiz ou presidente do tribunal deve mandar expedir mandado de citação para que se cumpra a determinação de recolhimento da contribuição social ou garanta-se a execução no prazo de quarenta e oito horas ${ }^{29}$.

27 "EMENTA Recurso extraordinário. Repercussão geral reconhecida. Competência da Justiça do
Trabalho. Alcance do art. 114, VIII, da Constituição Federal. 1 . A competência da Justiça do
Trabalho prevista no art. 114, VIII, da Constituição Federal alcança apenas a execução das
contribuições previdenciárias relativas ao objeto da condenação constante das sentenças que
proferir. 2. Recurso extraordinário conhecido e desprovido." (STF - RE: 569056 PA, Relator: Min.
MENEZES DIREITO, Data de Julgamento: 11/9/2008, Tribunal Pleno, Data de Publicação:
REPERCUSSÃO GERAL - MÉRITO)
28 "Art. 878-A. Faculta-se ao devedor o pagamento imediato da parte que entender devida à
Previdência Social, sem prejuízo da cobrança de eventuais diferenças encontradas na execução
ex officio."
29 "Art. 880 . Requerida a execução, o juiz ou presidente do tribunal mandará expedir mandado de
citação do executado, a fim de que cumpra a decisão ou o acordo no prazo, pelo modo e sob as
cominações estabelecidas ou, quando se tratar de pagamento em dinheiro, inclusive de 
Sérgio Pinto Martins ${ }^{30}$ bem observou que o dispositivo indica que a contribuição devida à União passa a fazer parte da execução das demais verbas trabalhistas decorrentes dos julgados proferidos na Justiça do Trabalho. Desse modo, não se aplica o artigo $8^{\circ}$ da Lei $n^{\circ} 6.830 / 80$ para fins de computo do prazo para pagamento da dívida ou garantia da execução, prevalecendo as quarenta e oito horas do dispositivo da CLT.

Guilherme Guimarães Feliciano ${ }^{31}$ afirmou que a nova redação dada ao artigo 880 da CLT retirou a legalidade do que se vinha praticando em alguns juízos trabalhistas após a vigência da Emenda $n^{\circ} 20 / 98$, iniciando a execução previdenciária somente após a extinção da execução trabalhista (artigo 794 do CPC). Essa prática, ilegal, após as alterações trazidas pela Lei $n^{\circ} 10.035 / 00$, demonstrava a tentativa desesperada dos magistrados em tentar equacionar a incompatibilidade procedimental entre os ritos da CLT e da Lei $n^{\circ} 6.830 / 80$, conciliando o regramento dos executivos fiscais, com seus traços peculiares e 0 aproveitamento do mesmo caderno processual (autos únicos). Além de evitar o tumulto processual, conferindo-se ao crédito trabalhista natural preeminência da ordem executiva no âmbito da Justiça do Trabalho.

Nos termos do artigo 884 da CLT, uma vez garantida a execução, inclusive no que diz respeito às contribuições sociais devidas ao INSS, o executado poderá apresentar embargos no prazo de cinco dias. O parágrafo $4^{\circ}$ do referido dispositivo, alterado pela Lei ํㅜ $10.035 / 00$, dispõe que os embargos e as impugnações à liquidação apresentadas pelos credores trabalhistas e previdenciários deverão ser julgados em conjunto, na mesma sentença.

No que pertine às práticas administrativas de recolhimento, foi incluído na CLT o artigo 889-A, segundo o qual os recolhimentos das importâncias devidas, referentes às contribuições sociais, seriam efetuados nas agências locais da Caixa Econômica Federal ou do Banco do Brasil S.A., por intermédio de documento de arrecadação da Previdência Social, dele se fazendo constar o número do processo.

contribuições sociais devidas à União, para que o faça em 48 (quarenta e oito) horas ou garanta a execução, sob pena de penhora." (Redação dada pela Lei no 11.457, de 2007).

${ }^{30}$ MARTINS, Sérgio Pinto. Comentários à CLT. 10ª ed. São Paulo: Atlas, 2013, p. 968-969.

${ }^{31}$ Op. cit., p. 98. 
Os parágrafos $1^{\circ} \mathrm{e} 2^{\circ}$, posteriormente alterados pela Lei $\mathrm{n}^{\circ} 11.457 / 07^{32}$, definiram que a execução da contribuição social ficaria suspensa até a integral quitação, quando comprovado nos autos a concessão de parcelamento do débito previdenciário perante a Secretaria da Receita Federal do Brasil, bem como que as varas do trabalho deveriam encaminhar mensalmente ao órgão competente as cópias das guias pertinentes aos recolhimentos efetivados nos autos, salvo se outro prazo for estabelecido em regulamento.

Por fim, a Lei $n^{\circ} 10.035 / 00$ alterou a redação dos parágrafos $3^{\circ}$ e $8^{\circ}$ do artigo 897 da CLT para definir que no agravo de petição previsto na alínea "a" deste artigo, o mesmo deve ser julgado pelo próprio Tribunal, presidido pela autoridade recorrida, salvo se se tratar de decisão de Juiz do Trabalho de $1^{\underline{a}}$ Instância ou de Juiz de Direito, quando o julgamento competirá a uma das Turmas do Tribunal Regional a que estiver subordinado o prolator da sentença, observado o disposto no artigo 679, a quem este remeterá as peças necessárias para o exame da matéria controvertida, em autos apartados, ou nos próprios autos, se tiver sido determinada a extração de carta de sentença.

O parágrafo $8^{\circ}$, por sua vez, estabeleceu que quando o agravo de petição versar apenas sobre as contribuições sociais, o juiz da execução determinará a extração de cópias das peças necessárias, que serão autuadas em apartado, conforme dispõe o parágrafo $3^{\circ}$, parte final, e remetidas à instância superior para apreciação, após contraminuta.

Nesse diapasão, além do recurso inominado previsto no parágrafo $4^{\circ}$ do artigo 832 da CLT, estão disponíveis ao INSS todos os demais institutos do sistema recursal trabalhista, sendo possível a utilização sempre que atendidos os requisitos formais e materiais de admissibilidade.

\footnotetext{
32 "§ 10 Concedido parcelamento pela Secretaria da Receita Federal do Brasil, o devedor juntará aos autos a comprovação do ajuste, ficando a execução da contribuição social correspondente suspensa até a quitação de todas as parcelas." (Redação dada pela Lei ํㅡ 11.457, de 2007).

"§ 20 As Varas do Trabalho encaminharão mensalmente à Secretaria da Receita Federal do Brasil informações sobre os recolhimentos efetivados nos autos, salvo se outro prazo for estabelecido em regulamento." (Redação dada pela Lei no 11.457, de 2007).
} 


\subsection{Emenda Constitucional $n^{\circ} 45$ de 30 de dezembro de 2004}

Por fim, a Emenda $n^{\circ} 45 / 04$ alterou novamente o texto constitucional para incluir a competência de execução, de ofício, das contribuições sociais previstas no artigo 195, I, a, e II, e seus acréscimos legais, decorrentes das sentenças que proferir entre os incisos do artigo $114^{33}$ e não mais na forma de parágrafo, como havia sido feito na Emenda $n^{\circ} 20 / 98$.

A referida alteração foi mais didática do que pragmática, na medida em que do ponto de vista científico podemos mensurar a razão de ser de tal alteração. O inciso é o desdobramento do artigo, que é a unidade básica da norma jurídica, dessa forma, o artigo 114, que traz a competência da Justiça do Trabalho tem como desdobramento a competência executória das contribuições sociais decorrentes de seus julgados.

Os parágrafos, por suas vezes, são mais como um desdobramento da própria norma jurídica inserida no artigo, ou seja, pode haver a sua complementação ou a indicação de exceção a esta. Dessa feita, se mostrou mais adequada a previsão da referida competência entre os demais incisos que tratam do desdobramento do artigo 114, que tem como norma básica a fixação da competência da Justiça do Trabalho.

Do ponto de vista histórico-evolutivo das normas que trataram de alguma forma dessa miscigenação material em ambiente processual trabalhista, eram essas as considerações necessárias para dar o devido suporte ao que se pretende discutir adiante.

\footnotetext{
33 "Art. 114. Compete à Justiça do Trabalho processar e julgar:

(...)

VIII a execução, de ofício, das contribuições sociais previstas no art. 195, I, a, e II, e seus acréscimos legais, decorrentes das sentenças que proferir;" (Incluído pela Emenda Constitucional ํㅜ 45, de 2004).
} 


\section{A CONTRIBUIÇÃO SOCIAL}

Feitas as considerações a respeito da evolução da norma trabalhista no sentido de se tornar possível atender ao fim arrecadatório enquanto decorrência lógica dos julgados produzidos pela Justiça Laboral, relevante tratar também da natureza jurídica desse crédito, de como se dá a sua constituição pelas vias ordinárias, bem como quais são as regras de extinção deste.

Mostra-se ainda mais relevante do ponto de vista da incidência normativa a confrontação entre a metodologia sui generis de arrecadação inserida no inciso VIII do artigo 114 da Constituição com os procedimentos convencionais de formalização do crédito.

Pretende-se demonstrar que a norma deve obedecer a pressupostos mínimos de validade para pertencer e ser inserida no universo de um determinado sistema jurídico, sob pena de poder ser considerada inválida para o intérprete, em que o próprio conceito de execução fiscal ex officio de um crédito jamais constituído, por si só, é antagônico ao sistema tributário e afronta a segurança jurídica, pilar do Estado democrático de Direito.

Assim, por conta dos efeitos fiscais decorrentes da produção de norma trabalhista individual e concreta por meio da sentença, da importância da arrecadação visando à manutenção da Seguridade Social e seu sistema protetivo e da possibilidade de desencadeamento de implicações previdenciárias, como a concessão de benefícios, o estudo da constituição do tributo sob a ótica do sistema tributário irá auxiliar nas críticas que se pretende fazer à execução fiscal na Justiça do Trabalho.

\subsection{Natureza Jurídica}

Ensina Sérgio Pinto Martins ${ }^{34}$ que a análise da natureza jurídica de um instituto é de suma importância para o seu enquadramento na categoria em que pertence no ramo do Direito.

No ramo do Direito Tributário, essa definição ganha mais relevância, considerando que o Estado apenas poderá exercer seu poder de fiscalização e arrecadação daquilo que for efetivamente tributo.

\footnotetext{
${ }^{34}$ MARTINS, Sérgio Pinto. Direito da Seguridade Social. 33a ed. São Paulo: Atlas, 2013, p. 68.
} 
Nesse sentido, Kiyoshi Harada ${ }^{35}$ assevera que o Estado, para promover o bem-estar comum, deve dispor de receitas originárias e derivadas, assim compreendidas, a primeira, aquelas que advêm da exploração de atividade econômica e, a segunda, caracterizadas pelo constrangimento legal para sua arrecadação, ou seja, os tributos, propriamente ditos, as penas pecuniárias, o confisco e as reparações de guerra.

Por isso, temos que os tributos, assim considerados aqueles que possuem tal natureza jurídica, constituem importante fonte de financiamento das políticas públicas promovidas pelo Estado na busca da concretização de seus objetivos.

O artigo $3^{\circ}$ do Código Tributário Nacional traz importante conceito para identificação dos tributos, sendo assim considerada toda prestação pecuniária compulsória, em moeda ou cujo valor nela se possa exprimir, que não constitua sanção de ato ilícito, instituída em lei e cobrada mediante atividade administrativa plenamente vinculada.

Além da conceituação e enquadramento em razão da natureza jurídica, importante frisar que o exercício da competência tributária pelos entes tributantes faz-se, também, de maneira limitada, nos termos do artigo 150 da Constituição.

Em relação à contribuição social, durante muito tempo persistiu a discussão, que tomou conta do universo jurídico, quanto à natureza jurídica que deveria ser atribuída à contribuição destinada ao custeio da seguridade social. Várias foram as correntes que surgiram para tentar defini-la de maneira mais apropriada.

Para Sérgio Pinto Martins ${ }^{36}$, é possível dividir em seis orientações as teorias que informam a natureza jurídica da contribuição previdenciária, quais sejam, a teoria do prêmio de seguro; a teoria do salário diferido; a teoria do salário atual; a teoria fiscal; a teoria parafiscal e a teoria da exação sui generis.

$\mathrm{Na}$ teoria do Prêmio de Seguro, confere-se um caráter sinalagmático à obrigação, equiparando-se a prestação paga para o custeio da previdência social ao prêmio pago pelo segurado em razão do risco assumido pelo segurador.

O contrato de seguro está previsto no artigo 757 do Código Civil, segundo o qual "pelo contrato de seguro, o segurador se obriga, mediante o pagamento do

\footnotetext{
${ }^{35}$ HARADA, Kiyoshi. Direito Financeiro e Tributário. 10 ${ }^{\underline{a}}$ ed. São Paulo: Atlas, 2010, p. 33.

${ }^{36}$ MARTINS, Sérgio Pinto. Direito da Seguridade Social. 33ª ed. São Paulo: Atlas, 2013, p. 68.
} 
prêmio, a garantir interesse legítimo do segurado, relativo a pessoa ou coisa, contra riscos predeterminados".

Acontece que, conforme bem assevera Sérgio Pinto Martins, essa ideia não se assemelha à de previdência social na medida em que esta também tem por objeto o amparo de pessoas necessitadas que sequer contribuem para o sistema, bem como tem por objetivo a distribuição de renda.

Outrossim, a questão da compulsoriedade da contribuição social é fator que afasta a ideia de seguro, pois o contribuinte não tem a faculdade de escolher pela cobertura ou não dos supostos riscos protegidos pelo sistema.

Já quem defende a teoria do salário diferido procura estabelecer um nexo de identidade entre a contribuição social e o salário percebido pelo obreiro, como se parte do salário não fosse entregue ao trabalhador, mas voltada para a seguridade social visando à formação de um fundo de recursos a ser distribuído no futuro na forma de benefício.

$\mathrm{Na}$ teoria do salário atual divide-se a remuneração do obreiro em duas cotas, uma paga diretamente ao trabalhador em razão do serviço prestado e outra destinada à seguridade social, visando à garantia de satisfação de necessidades futuras decorrentes de eventos previamente estabelecidos.

Existe ainda outra teoria, que é muito parecida e se confunde com a do salário diferido, a teoria do salário social, segundo a qual a contribuição social também é compreendida como uma espécie de poupança decorrente do salário devido pela sociedade ao trabalhador.

Segundo essa teoria, a contribuição social se equipararia a um salário devido pela sociedade em proveito do trabalhador, que é pago no futuro em detrimento das hipóteses legalmente previstas no ordenamento jurídico.

Para Jediael Galvão Miranda ${ }^{37}$, essa teoria estaria baseada no fato de que existe o valor destinado ao custeio da previdência social e que integraria o salário, o qual seria vertido para um fundo e retribuído a todos os segurados nas situações definidas em lei como socialmente justificáveis.

Acontece que a contribuição social não pode ser equiparada ao salário percebido pelo trabalhador, uma vez que pese existir uma parcela do custeio paga pelo empregador, o desconto feito na folha de pagamento é custeado pelo

\footnotetext{
${ }^{37}$ MIRANDA, Jediael Galvão. Direito da Seguridade Social. Rio de Janeiro: Elsevier, 2007, p. 36.
} 
próprio empregado, a sua incidência não decorre de contrato de trabalho, mas de imposição legal.

Em todas as teorias salariais da contribuição, a crítica que se faz é que, além de a parcela destinada à previdência social não ter natureza salarial nos moldes do artigo 457 da CLT, o autônomo, o empresário e o facultativo também podem ser contribuintes sem o percebimento de salário.

Nas palavras de Jediael Galvão Miranda ${ }^{38}$, qualquer que seja a vertente da teoria do salário adotada, a mesma deve ser criticada, na medida em que a relação salarial se dá em âmbito privado, entre patrão e empregado, sendo que o recolhimento da parcela referente ao custeio da previdência se trata de uma relação jurídica de direito público, da qual são partes diretamente o INSS e o empregador, que é o encarregado de promover todos os atos para esse fim. $O$ trabalhador não se torna credor da contribuição social, mas parte beneficiada pela cobertura securitária que dela decorre.

A doutrina e a jurisprudência vêm se consolidando no sentido da teoria fiscal, segundo a qual a contribuição social é um tributo. Ou seja, uma prestação pecuniária compulsória paga ao ente público, com a finalidade de constituir um fundo econômico para o custeio do serviço público.

Entretanto, na visão daqueles que discordam dessa teoria, a contribuição social não se enquadraria em nenhuma das três espécies de tributo, assim definidas nos artigos 145 da Constituição Federal e $5^{\circ}$ do Código Tributário Nacional: imposto, taxa e contribuição de melhoria.

$\mathrm{Na}$ teoria parafiscal, definida por aqueles que fazem essa distinção entre os tributos, a parafiscalidade do tributo estaria inserida na natureza de sua destinação. As contribuições assim consideradas estariam a sustentar encargos do Estado que não Ihe são próprios, como supostamente poderia ser o caso da

\footnotetext{
38 "....a teoria do salário, em qualquer de suas vertentes, sofre crítica por se basear em relação entre empregador e empregado, quando na realidade a relação jurídica é de direito público, desenvolvendo-se entre um ente público e o empregador, o empregado ou outro sujeito obrigado a recolher a contribuição. Além disso, o trabalhador não é credor das contribuições recolhidas, e sim das prestações previstas para atender a necessidades sociais acobertadas pela seguridade social, bem como se deve levar em consideração que há trabalhadores que não são assalariados, como os autônomos". (MIRANDA, Jediael Galvão. Direito da Seguridade Social. Rio de Janeiro: Elsevier, 2007, p. 37).
} 
contribuição social, em razão do seu não enquadramento em nenhuma das espécies tributárias ${ }^{39}$ dispostas nos dispositivos acima mencionados.

De toda sorte, inexistem grandes diferenças entre a teoria fiscal e a parafiscal, na medida em que ambas têm como núcleo a caracterização da natureza jurídica da contribuição social enquanto tributo.

Por fim, a teoria da exação sui generis tem por objetivo afastar a natureza fiscal da contribuição social, asseverando que se trata de uma imposição estatal atípica prevista na Constituição Federal e na legislação ordinária.

Partindo de uma análise semântica do direito, podemos dizer que em razão das várias espécies de tributos apresentarem características comuns, mesmo obedecendo a regimes jurídicos dos mais variados, o termo deve ser tomado enquanto gênero.

$\mathrm{Na}$ ótica de Leandro Paulsen ${ }^{40}$, em seu curso de direito tributário, não é possível a determinação das espécies de tributos a partir tão somente da análise do fato gerador nos termos do artigo $4^{\circ}$ do Código Tributário Nacional. Para o doutrinador, é imprescindível avaliar a finalidade e a promessa de restituição enquanto fatores de caracterização da espécie no gênero.

Assim, é fundamental a análise de todos os enunciados normativos presentes na Constituição Federal e no Código Tributário Nacional para se conseguir identificar todas as espécies tributárias presentes em nosso ordenamento.

Levando-se em consideração tão somente o teor dos artigos 145 da Constituição Federal e 5ำ do Código Tributário Nacional, poderíamos chegar a uma conclusão equivocada de que estaríamos diante de apenas três espécies de tributo, quais sejam, os impostos, as taxas e as contribuições de melhoria.

O artigo 145 dispõe que a União, os Estados, o Distrito Federal e os Municípios poderão instituir, enquanto tributos, apenas os impostos, as taxas e as contribuições de melhoria. Já o artigo $5^{\circ}$ do CTN, ao estabelecer o que são tributos, refere-se também somente a essas três espécies.

\footnotetext{
${ }^{39}$ Para Jediael Galvão Miranda: “...a contribuição social para a seguridade social seria uma exigência tributária destinada a acudir encargos que não são próprios ou típicos do Estado, sendo sujeito ativo de relação jurídica entidade da Administração pública indireta". (MIRANDA, Jediael Galvão. Direito da Seguridade Social. Rio de Janeiro: Elsevier, 2007, p. 37.)

${ }_{40}$ PAULSEN, Leandro. Curso de Direito Tributário. $2^{\mathrm{a}}$ ed. Porto Alegre: Livraria do Advogado, 2008, p. 39 e 40.
} 
Diante desses dois dispositivos, os quais à prima facie definem a natureza jurídica dos tributos, poderíamos chegar à conclusão de que o Direito Tributário Brasileiro adota uma teoria tripartida, obrigando-nos a afastar qualquer possibilidade de enquadramento da contribuição social no gênero.

Entretanto, para melhor compreender as espécies tributárias, é preciso localizar outras exações, além daquelas previstas no artigo 145, no texto da Constituição.

Seguindo essa linha, identificamos, por exemplo, que o artigo 148 autoriza a instituição de empréstimos compulsórios, assim como o artigo 149 prevê a existência das contribuições sociais, ambas de competência da União.

Dessa feita, fazendo uma interpretação sistemática do texto constitucional, diante da previsão do artigo 195, que dispõe que a seguridade social será financiada também pelas contribuições sociais, sendo a instituição destas de competência exclusiva da União, nos termos do artigo 149, o qual está inserido no capítulo que trata do Sistema Tributário Nacional, podemos concluir que o custeio da seguridade social tem sim natureza de tributo e assim deve ser compreendido para todos os fins, inclusive de constituição do crédito e extinção deste.

No entendimento de Eduardo Sabbag ${ }^{41}$, "as contribuições são tributos destinados ao financiamento de gastos específicos, sobrevindo o contexto de intervenção do Estado no campo social e econômico, sempre no cumprimento dos ditames da política de governo".

Até porque, ainda que quisesse o legislador ter configurado as contribuições como subespécies, haveria limitação no próprio texto constitucional, posto que a combinação do caput do artigo $4^{\circ}$ com 0 artigo 17 do Código Tributário Nacional fulminaria diversas exações de natureza fiscal ${ }^{42}$.

\footnotetext{
${ }^{41}$ SABBAG, Eduardo. Manual de Direito Tributário. 3a ed. São Paulo: Saraiva, 2011, p. 501.

${ }^{42}$ Nesse sentido destaca-se a lição de Luciano Amaro: "A combinação do art. 4ㅇ (caput) com o art. 17 do Código Tributário Nacional fulminaria diversas exações. Se o art. 17 (cópia do art. 5ํda Emenda n. 18/65) estabeleceu que "os impostos componentes do sistema tributário nacional são exclusivamente os que constam deste Título" (grifamos) não há como legitimar, por exemplo, a contribuição previdenciária recolhida pelas empresas. Com efeito, essa contribuição não é taxa de serviço (já que o Estado não presta, nem põe à disposição da empresa um serviço divisível, cuja fruição efetiva ou potencial pudesse servir de suporte fático para o tributo); também não é taxa de polícia (pois seu fato gerador não se confunde com nenhuma manifestação de exercício desse poder pelo Estado); obviamente, também não é contribuição de melhoria, nem se afina com o fato gerador de nenhum dos impostos integrantes do rol taxativo a que se referiu o art. 17". (AMARO, Luciano. Direito Tributário Brasileiro. $12^{\underline{a}}$ ed. rev. e atual. São Paulo: Saraiva, 2006, p. 57-58).
} 
Assumindo que na verdade existem outras espécies tributárias esparsas no texto constitucional, que este deve ser interpretado sistematicamente, que a seguridade social é custeada por contribuições sociais e que estas estão previstas no sistema tributário nacional, sendo importante entendermos um pouco melhor a natureza jurídica dessas contribuições previstas no artigo 149 da Constituição.

Cumpre-se destacar que existe corrente, como a encabeçada por Valdir de Oliveira Rocha ${ }^{43}$, a qual entende que as contribuições previstas no artigo 149 da Constituição não têm a natureza jurídica de tributo, pois, se tivessem, não haveria a necessidade de se fazer remissão ao artigo 146 da mesma norma, pois já estariam inseridas nas normas gerais tributárias.

Para Luiz Mélega ${ }^{44}$, que também é contrário à teoria que inclui as contribuições sociais na categoria das espécies tributárias, seria dispensável a determinação do artigo 149, que só se justifica exatamente para afastar tal natureza jurídica em relação às contribuições inseridas em tal dispositivo.

Ademais, para os defensores dessa teoria, a lógica de que existem apenas três espécies tributárias, assim definidas no artigo 145 da Constituição, estaria respaldada na ideia de que a lei não contém palavras inúteis e a remissão feita pelo artigo 149 estaria a demonstrar exatamente a ausência da natureza jurídica tributária das contribuições nele previstas.

Já para Sérgio Pinto Martins ${ }^{45}$, o artigo 149 da Constituição tem exatamente o condão de consagrar a natureza jurídica de tributo da contribuição social, pois está inserida no capítulo que trata do sistema tributário nacional.

Essa conclusão, conforme nos ensina Fábio Zambitte lbrahim, "decorre, basicamente, do enquadramento desta contribuição no conceito de tributo (art. $3^{\text {o }}$ do CTN) e do regime atribuído às contribuições sociais, previstas dentro do Capítulo referente ao Sistema Tributário Nacional (art. 149 da CRFB/88)".

Ademais, o próprio Supremo Tribunal Federal (STF), em sua função pacificadora, já se posicionou quanto à natureza jurídica tributária da contribuição social no julgamento do Recurso Extraordinário no 146.733-9/SP, o qual tinha

\footnotetext{
${ }^{43}$ ROCHA, Valdir de Oliveira. Determinação do montante do tributo. São Paulo: IOB, 1992.

44 "se as contribuições fossem tributos, a determinação do art. 149 seria dispensável. Aliás, ela só se justificaria pelo fato de tais contribuições não terem natureza tributária". (MÉLEGA, Luiz. Algumas reflexões sobre o regime jurídico das contribuições na Carta Política de 1988. Direito tributário atual. São Paulo: Resenha Tributária, $n^{\circ} 11 / 12$, p. 3.295, 1992.)

${ }^{45}$ MARTINS, Sérgio Pinto. Direito da Seguridade Social. 33a ed. São Paulo: Atlas, 2012, p. 76.
} 
como objeto a constitucionalidade da Lei $n^{\circ}$ 7.689/88, que previa a contribuição social sobre o lucro.

O STF decidiu que as contribuições sociais, com as demais contribuições previstas no artigo 149 da Constituição, constituem uma espécie diversa de tributo, tendo, portanto, natureza tributária.

Dessa feita, resta incontroverso o fato de se tratar a contribuição social de tributo destinado ao custeio da seguridade social, seja pela interpretação sistemática do ordenamento jurídico vigente ou pela própria aplicação prática pacificada pelos tribunais superiores.

\subsection{Constituição do Crédito Previdenciário}

Definida a natureza jurídica tributária da contribuição devida à seguridade para fins do presente estudo, importante a análise de como se dá a constituição desse crédito pelas vias ordinárias. Assim, passaremos a definir a forma como se opera a incidência da norma jurídica tributária nas relações sociais de forma a nascer o dever de se fazer exigir o recolhimento do tributo.

$\mathrm{Na}$ lição do tributarista Luciano Amaro ${ }^{46}$, a obrigação tributária decorre de uma imposição normativa, a qual desconsidera a vontade do sujeito passivo em aderir ou não a imposição nela prevista. Em ocorrendo o fato gerador previsto em lei, automaticamente nasce o potencial direito creditório do fisco.

Nesse diapasão, é o fato gerador previsto em lei o gatilho da obrigação tributária, o que significa dizer que, independentemente da vontade do sujeito passivo da obrigação, com o advento da hipótese prevista na legislação específica, nasce, em tese, o dever de recolhimento de determinado tributo.

Diferente não pode ser em relação à contribuição social, que, por se tratar de uma das espécies de tributo, necessariamente decorre do acontecimento de um fato gerador previsto em lei.

\footnotetext{
46 "o nascimento da obrigação tributária independe de uma manifestação de vontade do sujeito passivo dirigida a sua criação. Vale dizer, não se requer que o sujeito passivo queira obrigar-se; o vínculo obrigacional tributário abstrai a vontade e até o conhecimento do obrigado: ainda que o devedor ignore ter nascido a obrigação tributária, esta o vincula e o submete ao cumprimento da prestação que corresponda ao seu objeto. Por isso, a obrigação tributária diz-se ex lege. Do mesmo modo, a obrigação de votar, de servir às Forças Armadas, de servir como jurado, entre outras, são obrigações ex lege, que dispensam, para seu aperfeiçoamento, o concurso da vontade do obrigado". (AMARO, Luciano. Direito tributário brasileiro. 10ª ed. Atual. São Paulo: Saraiva, 2004, p. 240).
} 
O artigo 142 do Código Tributário Nacional dispõe que é de competência privativa da autoridade administrativa a constituição do crédito tributário por meio do ato administrativo denominado lançamento.

Assim, com a consumação do fato gerador tributário, é a autoridade administrativa que deve diligenciar para fins de constituição do crédito por meio de ato jurídico, seja pelo lançamento ou pela autuação quando do descumprimento de alguma obrigação tributária.

Por sua vez, o lançamento é entendido como o procedimento ou ato administrativo por meio do qual se verifica a ocorrência do fato gerador da obrigação correspondente, determina-se a matéria tributável, calcula-se o montante do tributo devido, identifica-se o sujeito passivo e, sendo o caso, propõe-se a aplicação da penalidade cabível.

Portanto, com base no ordenamento jurídico a que pertence o sistema tributário, o lançamento é o instrumento por meio do qual o sujeito ativo da obrigação exercita os atos de constituição do crédito para que seja possível a cobrança do tributo.

Tratando-se de ato administrativo, conclui-se que a cobrança judicial do tributo prescinde a existência de um procedimento administrativo de constituição do crédito, pois é por meio dele que se apura o montante devido tanto a título de tributo e os respectivos juros, como a título de multa pelo descumprimento da legislação tributária.

O Código Tributário Nacional prevê a existência de três modalidades de lançamento: 1) de ofício; 2) por declaração; e 3) por homologação.

No lançamento de ofício, previsto no artigo 149 do Código Tributário Nacional, compete ao sujeito ativo da obrigação dar as providências de verificação do fato gerador, identificação do sujeito passivo, cálculo do valor devido, constituição do crédito e notificação para pagamento, ou seja, o sujeito passivo não participa do lançamento, cabendo a ele tão somente o pagamento ou contestação do procedimento administrativo.

Já o lançamento por declaração é aquele em que o sujeito passivo da obrigação tributária, por determinação legal, tem o dever de prestar declarações sobre os fatos pertinentes à imposição tributária. Entretanto, é de competência do sujeito ativo, com base nessas informações do contribuinte, verificar a ocorrência 
do fato gerador, identificar o sujeito passivo, realizar o cálculo do montante devido, formalizar o crédito e notificar para pagamento.

Nesse caso, o sujeito passivo é parte determinante para a ocorrência do lançamento, na medida em que a declaração configura uma obrigação formal e destina-se a registrar dados fáticos relevantes para a autoridade administrativa concluir o ato ${ }^{47}$.

Por outro lado, no lançamento por homologação, o sujeito passivo é ainda mais determinante para fins de constituição do crédito tributário, pois é ele que verifica a ocorrência do fato gerador, calcula o montante devido e efetua 0 pagamento dentro do prazo legal, cabendo ao sujeito ativo tão somente a conferência da apuração feita pelo contribuinte e do pagamento realizados sem a interferência administrativa.

O artigo 150 do Código Tributário Nacional conceitua o lançamento por homologação, descrevendo-o como aquele que ocorre quando a legislação atribua ao sujeito passivo da obrigação tributária a obrigação de antecipar o pagamento sem que haja uma prévia avaliação por parte da Administração Pública, à qual cabe tão somente a homologação do ato praticado pelo particular ${ }^{48}$.

Nessa modalidade de constituição de crédito tributário, o ato do particular, formalizando a obrigação tributária, sem dúvida, é o que torna possível o recolhimento do tributo devido, sem qualquer interferência do EstadoAdministração. Assim como no lançamento de ofício ou por declaração, opera-se a descrição de um evento do mundo físico-social, ocorrido em condições determinadas de espaço e tempo, que guarda estreita consonância com os critérios estabelecidos na hipótese de uma norma geral e abstrata.

Entretanto, nosso sistema tributário fez a opção de não considerar o ato do contribuinte como lançamento, colocando no singelo ato de homologação, ainda que tácito, a força de selo confirmatório de que toda autuosidade do particular necessitaria para se transformar em ato jurídico administrativo.

\footnotetext{
47 "CTN, Art. 147. O lançamento é efetuado com base na declaração do sujeito passivo ou de terceiro, quando um ou outro, na forma da legislação tributária, presta à autoridade administrativa informações sobre matéria de fato, indispensáveis à sua efetivação."

48 "O lançamento por homologação, que ocorre quanto aos tributos cuja legislação atribua ao sujeito passivo o dever de antecipar o pagamento sem prévio exame da autoridade administrativa, opera-se pelo ato em que a referida autoridade, tomando conhecimento da atividade assim exercida pelo obrigado, expressamente a homologa."
} 
Entretanto, esse ato de homologação não passa de mero exercício de fiscalização por parte da administração, sendo o documento oferecido pelo sujeito passivo suficiente para as providências instauradoras da execução judicial.

Nesse contexto, não há como se descaracterizar, salvo nas hipóteses comprovadas de dolo, fraude ou simulação, a modalidade de lançamento por homologação, no caso da contribuição social, na medida em que cabe ao empregador, sujeito passivo da obrigação tributária uma série de providências para a constituição do crédito, tais como a inclusão do empregado na folha de remuneração, a apuração periódica do montante da contribuição social devida e a comunicação ao fisco. Ausentes tais elementos, não há que se falar em lançamento por homologação, pois nada existe para ser homologado pelo fisco expressa ou tacitamente pelo decurso do prazo de extinção do crédito tributário.

Conforme disposto no parágrafo $7^{\circ}$ do artigo 33 da Lei o 8.212 de 1991 , com as alterações decorrentes da conversão da Medida Provisória 449/08 na Lei № 11.941/09, o crédito devido à seguridade social é constituído por meio de notificação de lançamento, de auto de infração e de confissão de valores devidos e não recolhidos pelo contribuinte.

Detalhando o procedimento, a Instrução Normativa da Receita Federal de n॰971/2009 traz expresso no artigo 456 que a constituição desse crédito se dará por meio de lançamento por homologação expressa ou tácita, mediante declaração do ARO, na forma do artigo 340 , ou da GFIP, comunicando a existência de crédito tributário.

Outrossim, o referido dispositivo prevê também a modalidade de constituição por meio de reconhecimento espontâneo de dívida tributária, hipótese que se concretiza quando o sujeito passivo apresentar a Guia de Recolhimento do Fundo de Garantia por Tempo de Serviço e Informações à Previdência Social (GFIP) e não efetuar o seu pagamento integral ou quando reconhecer espontaneamente a obrigação tributária.

A GFIP foi introduzida no sistema jurídico tributário para atuar como instrumento introdutor de norma de constituição de crédito pela Lei no 9.528 de 1997. Desse modo, desde a competência de janeiro de 1999, todas as pessoas físicas ou jurídicas sujeitas ao recolhimento das contribuições e/ou informações à Previdência Social, conforme disposto nas Leis ํㅜ 8.212 de 1991 e ํㅡ 8.213 de 1991 e legislação posterior, estão obrigadas ao cumprimento desse ato. 
Trata-se de documento/formulário por meio do qual deverão ser informados os dados da empresa e dos trabalhadores, os fatos geradores de contribuições previdenciárias e os valores devidos ao INSS, bem como as remunerações dos trabalhadores e valor a ser recolhido ao Fundo de Garantia por Tempo de Serviço (FGTS).

A obrigatoriedade vinculada ao sujeito passivo da obrigação tributária em proceder ao preenchimento e entrega da GFIP ainda que não haja recolhimento, hipótese em que esta terá natureza meramente declaratória, contendo todas as informações cadastrais e financeiras de interesse da Previdência Social e necessárias para eventual apuração de regularidade na ausência de recolhimento do tributo.

A instrução normativa da Receita Federal ainda prevê a hipótese de constituição do crédito previdenciário pelo lançamento de ofício, que se dá pela atuação do fisco quando constatada a falta de recolhimento de qualquer contribuição ou outra importância devida nos termos da legislação aplicável, bem como quando houver o descumprimento de obrigações acessórias.

Cumpre-se destacar que a GFIP é, portanto, documento de confissão de dívida, por se tratar do instrumento introdutor da norma fiscal previdenciária no sistema jurídico à que pertence, bem como pelo fato da regra geral ser a de que a constituição do crédito devido à seguridade social se dá pelo lançamento por homologação.

Assim, se o sistema da Receita Federal detectar divergência entre as informações declaradas em GFIP e os recolhimentos decorrentes desta, poderá dar início à cobrança automática, independentemente da instauração de procedimento fiscal ou notificação do sujeito passivo.

O artigo 460 da Instrução Normativa da Receita Federal $n^{\circ} 456^{49}$, com as suas últimas alterações, prevê de forma específica quais os documentos de

\footnotetext{
49 "Art. 460. São documentos de constituição do crédito tributário relativo às contribuições de que trata esta Instrução Normativa:

I - Guia de Recolhimento do Fundo de Garantia do Tempo de Serviço e Informações à Previdência Social (GFIP), é o documento declaratório da obrigação, caracterizado como instrumento hábil e suficiente para a exigência do crédito tributário;

II - Lançamento do Débito Confessado (LDC), é o documento por meio do qual o sujeito passivo confessa os débitos que verifica;

III - Auto de Infração (Al), é o documento constitutivo de crédito, inclusive relativo à multa aplicada em decorrência do descumprimento de obrigação acessória, lavrado por AFRFB e apurado mediante procedimento de fiscalização;
} 
constituição do crédito previdenciário, ou seja, quais os suportes físicos previstos em lei, nos quais são inseridas as normas individuais aos casos concretos de modo a inserir no mundo jurídico a norma fiscal.

Dessa feita, podemos concluir que por se tratar de espécie tributária cujo crédito é constituído, em regra, por meio de lançamento de homologação, é a GFIP o instrumento introdutor da norma jurídica individual e concreta no sistema tributário, cabendo ao fisco a homologação ou penalização em caso de descumprimento dos preceitos legais inerentes ao sistema ao qual pertence.

Nos demais casos, cabe à Administração Pública, pelo lançamento de ofício, constituir o crédito tributário, desde que respeitado o prazo decadencial, o qual será aprofundado em item específico.

A interpretação dada para justificar a executoriedade da contribuição social pela Justiça do Trabalho é a acessoriedade dos efeitos da sentença em relação à União, a qual se equipara a decisão que determina o pagamento das custas judiciais ao vencido.

Entretanto, o inciso VIII do artigo 114 da Constituição acabou inserindo no ordenamento jurídico a previsão de execução incidental, da qual a União não fez parte em fase de conhecimento, bem como não é parte na fase executiva da condenação das verbas trabalhistas.

A União, portanto, é parte credora no processo de execução, não sendo possível o enquadramento como terceiro interessado, como alguns podem defender.

O dilema dogmático gira em torno do fato de que inexiste para a União título executivo judicial ou extrajudicial que justifique a execução de ofício. 0 crédito surge no mundo jurídico como uma consequência lógica da sentença

IV - Notificação de Lançamento (NL), é o documento constitutivo de crédito expedido pelo órgão da Administração Tributária;

V - Débito Confessado em GFIP (DCG), é o documento que registra o débito decorrente de divergência entre os valores recolhidos em documento de arrecadação previdenciária e os declarados em GFIP; e

VI - Lançamento de Débito Confessado em GFIP (LDCG), é o documento que registra o débito decorrente de ratificação espontânea e expressa do sujeito passivo, referente aos valores confessados na GFIP, não recolhidos nem incluídos em DCG. (Revogado pela Instrução Normativa RFB no 1.027, de 20 de abril de 2010)

VII - Aviso para Regularização de Obra (ARO), emitido na forma prevista no art. 340, a partir das informações prestadas na Declaração e Informação sobre Obra (DISO), é o documento por meio do qual o sujeito passivo confessa os valores das contribuições oriundos da aferição indireta de obra de construção civil de sua responsabilidade." (Incluído pela Instrução Normativa RFB № 1.477, de 3 de julho de 2014). 
transitada em julgado e não enquanto resultado de um procedimento fiscal de constituição.

Não fazendo parte do processo de conhecimento, não há justificativa para embasar tese que sustente a existência de título judicial para fins de execução em favor da União.

Outrossim, não é possível atribuir à sentença trabalhista caráter de lançamento ou de título de inscrição na dívida ativa do crédito previdenciário, principalmente em razão da ausência de procedimento de constituição do crédito que permita a ampla possibilidade de impugnação por parte do sujeito passivo da obrigação tributária.

Conforme afirma Sérgio Pinto Martins ${ }^{50}$, a União surge do nada, para exigir, já na fase de execução, a contribuição social decorrente da sentença trabalhista.

É fato que a União tem legitimidade e competência para a constituição e execução do crédito previdenciário decorrente de sentença trabalhista, acontece que o formato atual acaba por desprestigiar as formalidades inerentes ao sistema tributário na constituição do crédito.

\subsection{Impacto do e-Social no Lançamento Tributário}

Conforme é de conhecimento comum, está em vias de ser implantado o sistema de integração das informações por meio eletrônico, desenvolvido para aperfeiçoar a arrecadação e a troca de informações entre as entidades interessadas.

O e-Social, como é denominado esse sistema, é um projeto do Governo Federal integrante do Sistema Público de Escrituração Digital (SPED), instituído pelo Decreto №. 6.022, de 22 de janeiro de 2007, que visa, de maneira geral, a informatização e modernização na sistemática de cumprimento das obrigações dos contribuintes.

Nos termos do atual Manual de Orientações ${ }^{51}$, versão 1.1, publicada em 6/1/2014, o e-Social institui forma única de prestação das informações trabalhistas, previdenciárias, tributárias e fiscais para trabalhadores remunerados,

${ }^{50}$ MARTINS, Sérgio Pinto. Execução da contribuição previdenciária na justiça do trabalho. $3^{\text {a }}$ ed. São Paulo: Atlas, 2008, p. 26.

${ }^{51}$ http://www.esocial.gov.br/Leiautes.aspx (acesso em 28/11/2014). 
com ou sem vínculo empregatício, assim como outras informações previdenciárias dispostas na Lei no 8.212/91, além dos rendimentos pagos sujeitos à retenção na fonte.

Esse projeto, a partir de sua implantação, substituirá o procedimento de envio de informações por meio das diversas declarações, formulários, termos e documentos relativos à relação de trabalho, que passarão a ser cumpridas por meio de envio de eventos, que serão classificados em iniciais, de tabela, periódicos e não periódicos.

Os eventos iniciais são aqueles de identificação do empregador/contribuinte com informações de sua classificação fiscal e estrutura administrativa. Os de tabela complementam os iniciais com uma série de informações que darão validade aos periódicos e não periódicos. Estes últimos, por sua vez, representam as ocorrências cuja periodicidade é definida e as ocorrências que não têm data pré-fixada para acontecerem.

Para fins de apuração da sistemática de constituição do crédito previdenciário, será dado enfoque aos eventos periódicos, que se caracterizam pelas informações relativas à folha de pagamento e a fatos geradores das contribuições previdenciárias e de Imposto de Renda Retido na Fonte, bem como das informações de retenção das contribuições sociais incidentes sobre pagamentos feitos para pessoas jurídicas.

De acordo com as diretrizes do governo, as informações coletadas no eSocial serão armazenadas no denominado Ambiente Nacional do e-Social e poderão ser utilizadas "para fins previdenciários, fiscais e de apuração de tributos e do FGTS", por todos os entes participantes do projeto, quais sejam, Secretaria da Receita Federal do Brasil (RFB), Instituto Nacional do Seguro Social (INSS), Ministério da Previdência Social (MPS), Ministério do Trabalho e Emprego (MTE) e Caixa Econômica Federal (CEF).

Nesse sentido, é possível inferir que as informações prestadas pelos eventos periódicos, a partir da implantação do e-Social, terão força declaratória, podendo ser utilizadas pelos entes acima mencionados para o cálculo do quantum devido, caso este não proceda o respectivo recolhimento até a data limite.

Não obstante ainda não existir previsão legal para tanto, no que se refere aos contribuintes das empresas de grande porte e micro e pequenas empresas, a 
edição da Lei $n^{0}$ 12.873/13 trouxe algumas alterações significativas na Lei № 8.212/91 para os segurados especiais, que demonstram a direção que provavelmente deve ser tomada.

Em especial, no sentido de que as informações prestadas no sistema eletrônico têm caráter declaratório, constituindo instrumento hábil e suficiente para a exigência dos tributos e encargos apurados e substituirão a obrigatoriedade de entrega de todas as informações, formulários e declarações a que está sujeito o grupo familiar, inclusive as relativas ao recolhimento do FGTS ${ }^{52}$.

Os segurados especiais estão previstos no parágrafo 8ำ do artigo 195 da Constituição ${ }^{53}$, que embora não contenha a expressão "segurado especial", traz exatamente a intenção do legislador em atribuir classificação distinta a esse contribuinte.

De qualquer forma, o conceito trazido no inciso VII dos artigos 12 da Lei nº 8.212/1991 e artigo 11 da Lei no 8.213/1991 elucida qualquer dúvida que possa ser suscitada.

Ora, se para o segurado especial, ao qual a própria Constituição concedeu tratamento diferenciado, dada sua hipossuficiência em relação aos demais, as informações prestadas terão força declaratória, a lógica é que para os demais contribuintes, também o terão. Já existe, inclusive, previsão para estender a sistemática de prestação de informação e recolhimento aos produtores rurais pessoas físicas, conforme dispõe o parágrafo $13^{\circ}$ do artigo $32-\mathrm{C}$ da Lei $\mathrm{n}^{\circ}$ $12.873 / 13$.

\footnotetext{
52 "Art. 32-C O segurado especial responsável pelo grupo familiar que contratar na forma do § 80 do art. 12 apresentará as informações relacionadas ao registro de trabalhadores, aos fatos geradores, à base de cálculo e aos valores das contribuições devidas à Previdência Social e ao Fundo de Garantia do Tempo de Serviço - FGTS e outras informações de interesse da Secretaria da Receita Federal do Brasil, do Ministério da Previdência Social, do Ministério do Trabalho e Emprego e do Conselho Curador do FGTS, por meio de sistema eletrônico com entrada única de dados, e efetuará os recolhimentos por meio de documento único de arrecadação. (...) $\S 2^{\circ}$ As informações prestadas no sistema eletrônico de que trata o caput têm caráter declaratório, constituem instrumento hábil e suficiente para a exigência dos tributos e encargos apurados e substituirão, na forma regulamentada pelo ato conjunto que prevê o $\S 10$, a obrigatoriedade de entrega de todas as informações, formulários e declarações a que está sujeito o grupo familiar, inclusive as relativas ao recolhimento do FGTS. (...) § 13. A sistemática de entrega das informações e recolhimentos de que trata o caput poderá ser estendida pelas autoridades previstas no $\S 10$ para o produtor rural pessoa física de que trata a alínea a do inciso $\mathrm{V}$ do caput do art. 12."

53 "Art. 195 (...) $\S 8$ o 0 produtor, o parceiro, o meeiro e o arrendatário rurais e o pescador artesanal, bem como os respectivos cônjuges, que exerçam suas atividades em regime de economia familiar, sem empregados permanentes, contribuirão para a seguridade social mediante a aplicação de uma alíquota sobre o resultado da comercialização da produção e farão jus aos benefícios nos termos da lei."
} 
Dessa forma, a partir do momento em que as empresas enviarem os eventos de admissão dos trabalhadores, bem como os eventos de ausência de vínculo empregatício, todos os entes consorciados terão condições de apurar irregularidades no pagamento das contribuições, caso sejam devidas.

Especificamente no tocante à contribuição previdenciária, é possível argumentar, então, que a relação Fisco-Contribuinte será sensivelmente alterada, uma vez que a ausência de informação tende a ser detectada de maneira mais ágil, considerando que com o envio dos eventos periódicos, em substituição à geração da GFIP, a Receita Federal já estará de posse de todas as informações necessárias para homologação ou para constituição do crédito tributário, independentemente da atuação do contribuinte.

Diante disso, a mera ausência de prestação da informação, ou seja, o não envio dos eventos periódicos, já seria suficiente para caracterizar a irregularidade e impor sanções à empresa, pois não havendo qualquer isenção legal para o não recolhimento, o mesmo é devido para o trabalhador que figura como segurado obrigatório nos termos do artigo 11 da Lei oㅡ 8.213/91.

Acontece que se a informação não for lançada no sistema desde a sua origem, permanecerá a dificuldade na apuração de qualquer irregularidade, visto que a ausência do envio de periódico somente será sentida pelo fisco se em algum momento tiverem sido incluídos pelo empregador os dados da contratação do trabalhador.

Todavia, importante ressaltar que o procedimento acima descrito é válido apenas para os fatos geradores posteriores à vigência da lei, já que o texto é explícito ao condicionar que terão força declaratória apenas as declarações prestadas no meio eletrônico, que terá entrada única de dados para a RFB, INSS, MPS, MTE e CEF.

No tocante à vigência, assim definiu a referida Lei oㅜ 12.873/13 em seu artigo 63, que esta se dará no primeiro dia do sétimo mês subsequente à data de sua publicação, em relação ao artigo $32-C$ da Lei $n^{0} 8.212$, de 24 de julho de 1991. Outrossim, de acordo com a nova redação dada ao parágrafo $1^{\circ}$ do artigo 32-C da Lei o 8.212/1991, caberá aos entes participantes, em ato conjunto, dispor sobre "a prestação das informações, a apuração, o recolhimento e a distribuição dos recursos recolhidos e sobre as informações geradas por meio do sistema eletrônico e da guia de recolhimento de que trata o caput'. 
Considerando que o meio eletrônico a que se refere a já vigente Lei $n$ o 12.873/13 é o próprio e-Social, são inaplicáveis os seus dispositivos enquanto este ainda não estiver disponível. Esse, inclusive é o posicionamento do Comitê Gestor do Projeto divulgado em 22/5/2014, no qual informou que o prazo para implantação do e-Social apenas começará a ser contado quando da publicação da versão definitiva do manual de orientações ${ }^{54}$.

O cronograma a que se refere a informação supra, segundo notícias recentes ${ }^{55}$, é:

- Dezembro 2014: Publicação da Portaria e disponibilização do Manual;

- Seis meses após: Liberação do ambiente para testes por todas as empresas;

- Janeiro 2016: Envio oficial dos arquivos por empresas com faturamento igual ou acima de 78 milhões;

- Meados de 2016: Envio oficial dos arquivos por empresas com faturamento igual ou acima de 3,6 milhões.

Em relação ao cronograma, para as micro e pequenas empresas ainda não há uma definição, pois está pendente 0 acordo com as entidades representativas desse segmento.

Portanto, até a efetiva implantação do e-Social, bem como para as competências anteriores à sua vigência, as informações das contribuições previdenciárias devem ser prestadas e recolhidas por meio da GFIP, nos termos das Leis n 8.212/91 e no 8.213/91, sendo esse formulário, além do lançamento de ofício, o único capaz de reconhecer o débito da empresa por meio do lançamento por homologação, conforme já abordado no item anterior.

\subsection{Prescrição e Decadência}

Definidas as questões atinentes à natureza jurídica das contribuições vertidas pelos segurados e empregadores para custear o sistema de seguridade social do país, em especial o pagamento de benefícios de origem previdenciária, bem como a forma de constituição desse crédito pelas vias ordinárias previstas no sistema jurídico à que pertence, importante tecer alguns comentários quanto ao tempo para constituição e exigência do crédito tributário.

\footnotetext{
54 http://www.esocial.gov.br/NotalmprensaPrazo.aspx (acesso em 9/12/2014).

55 http://www.taxaccounting.com.br/noticias/ver.asp?not_id=11743 (acesso em 2/12/2014).
} 
Esses conceitos terão importância para o próximo capítulo, quando será tratada a metodologia para a execução de tributo cujo crédito jamais foi constituído, bem como para o Capítulo 5, no qual inserimos a ideia de necessidade da arrecadação para os fins de manutenção da Seguridade Social.

Se houver falhas no mecanismo inserido pelo inciso VIII do artigo $114 \mathrm{da}$ Constituição, a finalidade de fortalecimento na arrecadação pode ir por água abaixo, mostrando-se injustificada a relativização das formalidades decorrentes do Sistema Tributário na execução de seus créditos.

É certo que o prazo para a instauração de litígios decorrentes da ilicitude dos fatos e atos do dia a dia trata-se de importante ferramenta garantidora da segurança e certeza do direito.

A possibilidade de exigibilidade ad eternum de um tributo, portanto, é hipótese causadora de insegurança jurídica, que deve ser rechaçada nos termos da ordem emanada pela Constituição.

Dessa feita, é exatamente nesse contexto que os institutos da prescrição e decadência em matéria tributária vão servir de controle temporal de incidência normativa, em especial para constituição e exigibilidade da contribuição social, que após o advento das emendas constitucionais passaram a ser, também, executadas na justiça do trabalho.

Para fins tributários, a decadência pode ser entendida como a perda do direito para lançamento do crédito por parte da Fazenda Pública por sua própria inércia. O Código Tributário Nacional cuida do tema em seus artigos 150, parágrafo $4^{\circ}, 156$, inciso $\mathrm{V}$ e 173.

Por outro lado, a prescrição, em que pese também tratar de modalidade extintiva da obrigação tributária, relaciona-se com o decurso do prazo legal para a propositura de medida de cobrança do crédito já lançado.

$\mathrm{Na}$ contagem do prazo decadencial, importantíssima a constatação do fato gerador do tributo para o qual se pretenda efetivar o lançamento, pois é com o acontecimento desse evento que se tem início o prazo para que ocorra a ação humana por agente competente para constituir e lançar o crédito dele decorrente, nos termos do parágrafo $4^{\circ}$ do artigo 150 do Código Tributário Nacional.

Outrossim, comprovada a má-fé do sujeito passivo da obrigação tributária, ou seja, quando não há qualquer declaração ou recolhimento no momento 
oportuno, aplicar-se-á a regra do inciso I do artigo 173, do Código Tributário Nacional.

Nesse contexto, se houve algum recolhimento, por menor que seja, temse início o curso do prazo decadencial, entretanto, se inexiste qualquer declaração ou pagamento do tributo, o prazo terá início no primeiro dia do exercício subsequente.

Em relação ao termo a quo do prazo prescricional, esse se inicia no momento em que o tal crédito é definitivamente constituído e lançado dentro do prazo legal, sem que seja consumado pelos efeitos da decadência.

No caso da contribuição social, a Lei o 8.212/91 dispunha em sua redação original sobre a decadência e a prescrição em seus artigos 45 e 46, em que o marco de contagem do prazo decadencial inicia-se: I. no primeiro dia do exercício seguinte àquele em que o crédito poderia ter sido constituído; ou II. na data em que se tornar definitiva a decisão que houver anulado, por vício formal, a constituição de crédito anteriormente efetuada.

Cumpre-se destacar o fato que tanto no que pertine à decadência, quanto à prescrição, o referido diploma legal previa o prazo de dez anos para constituição e lançamento, assim como para cobrança do crédito tributário decorrente da contribuição destinada ao custeio da seguridade social.

Entretanto, esses dispositivos contrariavam normas de maior hierarquia, visto que o Código Tributário Nacional prevê prazo de cinco anos para que a Fazenda Pública constitua o crédito tributário, nos termo do artigo 173, o qual tem redação muito semelhante à do artigo 45 , revogado pela Lei Complementar $n^{\circ}$ 128/2008.

Conforme vimos anteriormente, tornou-se inequívoca a natureza jurídica tributária das contribuições para a seguridade social, em que a decadência e a prescrição passaram a seguir, portanto, as regras previstas no Código Tributário Nacional, ou seja, o prazo para constituição e lançamento, assim como para cobrança do crédito lançado passou a ser quinquenal. 
O já extinto Tribunal Federal de Recursos, em razão das discussões atinentes à natureza jurídica da contribuição social, previa a aplicação do prazo de cinco anos nos termos da Súmula $219^{56}$.

Ademais, uma vez definida a natureza jurídica de tributo da contribuição à seguridade social, que se enquadra na hipótese do artigo 149 da Constituição, torna-se imperativa a aplicação de todos os preceitos jurídicos inerentes ao Sistema Jurídico Tributário.

O referido artigo 149 faz remissão expressa ao inciso III do artigo 146 da mesma norma, em que a alínea "b" estabelece que os prazos de prescrição e decadência devem ser previstos por lei complementar, o que não é o caso da Lei no 8.212/91, a qual, portanto, jamais poderia contrariar a determinação legal inserida no Código Tributário Nacional.

O objeto do estudo do presente trabalho é a contribuição social, em especial aquela executada de ofício pela Justiça do Trabalho. Logo, não se pode tirar de foco o fato de a referida contribuição se tratar de uma espécie do gênero tributo, em que o seu estudo deve ser pautado pelo sistema jurídico previsto no Direito Tributário.

Quanto à decadência e à prescrição, importante ressaltar as peculiaridades atinentes ao direito tributário, na medida em que se tratam de hipóteses de extinção do crédito, no caso daquele decorrente da contribuição social. No âmbito em enfoque, é possível verificar um marco de ordem prática que separa a contagem prescricional da decadência, qual seja, o lançamento.

Conforme o magistério de Paulo de Barros de Carvalho ${ }^{57}$, o lançamento tributário é um ato administrativo mediante o qual se insere na ordem jurídica nacional norma de caráter individual e concreto. Assi, no antecedente dessa norma estará descrito o fato jurídico tributário e no seu consequente a formalização do vínculo obrigacional.

\footnotetext{
56 "Não havendo antecipação de pagamento, o direito de constituir seu crédito previdenciário extingue-se decorridos 5 anos do primeiro dia do exercício seguinte àquele em que ocorreu o fato gerador".

57 "Lançamento tributário é o ato jurídico administrativo, da categoria dos simples, constitutivos e vinculados, mediante $o$ qual se insere na ordem jurídica brasileira uma norma individual e concreta, que tem como antecedente o fato jurídico tributário e, como conseqüente, a formalização do vínculo obrigacional pela individualização dos sujeitos ativo e passivo, a determinação do objeto da prestação, formado pela base de cálculo e correspondente alíquota, bem como pelo estabelecimento dos termos espaço-temporais em que o crédito há de ser exigido." (in Curso de direito tributário. $21^{\text {a }}$ ed. São Paulo: Saraiva, 2009, p. 390.)
} 
Em outras palavras, o lançamento pode ser definido como um ato administrativo, embasado no entendimento de que, por procedimento, entende-se o processo de preparação. O ato é tido como o produto final desse procedimento.

Esse produto (o ato) é constituído pelos enunciados prescritivos e embasado no documento (suporte físico do lançamento), que por ter sido vertido em linguagem competente passa a integrar o sistema do direito positivo.

Poderíamos ser mais detalhistas e dizer que o lançamento tributário é, sim, ato jurídico administrativo, afinal insere no ordenamento uma norma individual e concreta.

Entretanto, não é nenhum absurdo afirmar que no antecedente dessa norma individual e concreta temos um relato do evento tributário tipificado e, no consequente, a prescrição do vínculo que nasce para unir os sujeitos por uma prestação pecuniária. Seguindo esse raciocínio, poderíamos dizer que essa norma apresenta um caráter declaratório do fato e constitutivo da relação.

O lançamento tributário em sentido amplo poderia ser conceituado como o veículo introdutor de uma norma individual e concreta, por meio do qual, após a subsunção do fato, a norma geral e abstrata constitui-se o crédito tributário.

Em sentido estrito, poderíamos nos manter com a definição do artigo 142 do Código Tributário Nacional, segundo a qual o lançamento é o procedimento privativo da autoridade administrativa, vinculado e obrigatório que visa verificar a ocorrência do fato jurídico, determinar a matéria tributável, calcular o montante do tributo devido, identificar o sujeito passivo e, quando for o caso, aplicar a penalidade cabível.

Muito se fala em modalidades de lançamento, sendo essa classificação decorrente do grau de colaboração do contribuinte, com vistas à realização do ato, conforme pudemos observar anteriormente.

No lançamento ex officio (artigo 149, CTN), não há participação do contribuinte, na medida em que todas as providências são tomadas por iniciativa da autoridade administrativa, sem qualquer intervenção do sujeito passivo.

Já no lançamento por declaração (artigo 147, CTN), fisco e contribuinte colaboram, visando aos resultados finais do lançamento.

Por sua vez no lançamento por homologação (artigo 150, CTN), não há o lançamento propriamente dito, mas a colaboração praticamente isolada do 
administrado, cabendo ao fisco tão somente a homologação (expressa ou tácita) ou não dos atos praticados.

Frisemos que, além do lançamento, o crédito tributário também pode ser constituído por meio de auto de infração, em que ambos são tratados como atos administrativos e, na prática, representam um único documento.

Ocorre que para a avaliação científica, é essencial diferenciar os objetivos de cada um. Nesse sentido, ao passo que o lançamento decorre de um fato jurídico lícito gerador do crédito tributário, o auto de infração tem como condão a imposição de penalidade prevista em lei, em razão da ilicitude praticada, tendo, portanto, caráter sancionatório.

De toda sorte, do ponto de vista pragmático, essa diferença só é possível de ser observada no antecedente normativo da norma, ou seja, no lançamento, visto que no consequente, leia-se auto de infração, temos a obediência da mesma regra, inclusive no que se refere à alíquota e base de cálculo, no caso de sanção pecuniária, e dever instrumental ou formal quando não pecuniária.

Ainda sob o aspecto prático, poderíamos falar em auto de infração em sentido amplo, referindo-se àquele que abarca tanto o ato de lançamento, quanto $\mathrm{o}$ ato sancionatório e, em sentido estrito, nos referindo apenas à constituição da penalidade imposta pelo descumprimento de uma norma geral e abstrata. Mister se faz evidenciar, porém, que esse aspecto híbrido não retira a natureza distinta de um ou de outro.

Nesse sentido, podemos concluir que o lançamento, no que se refere ao relato de um fato pretérito, assume uma função declaratória, enquanto no consequente dessa mesma norma, onde se prescreve a relação jurídica propriamente dita, assume uma função constitutiva ${ }^{58}$.

\footnotetext{
58 "Meditemos sobre a construção desse segmento de linguagem. Seu conteúdo semântico será o relato de um evento do passado, devidamente caracterizado no tempo e no espaço. Dizendo de outro modo, o enunciado de que tratamos declara ter ocorrido uma alteração no plano físicosocial. Nesse sentido, vale dizer que o fato jurídico tributário tem caráter declaratório. Aí está o motivo pelo qual se aplica ao fato a legislação em vigor no momento em que o evento ocorreu. Entretanto, não podemos esquecer que o relato do acontecimento pretérito é exatamente o modo como se constitui o fato, como essa entidade aparece e é recebida no recinto do direito, o que nos autoriza a proclamá-lo como constitutivo do evento que, sem esse relato, quedaria a margem do universo jurídico. Por outros torneios, o enunciado projeta-se para o passado, recolhe o evento e, ao descrevê-lo, constitui-se como fato jurídico tributário. Retenhamos esses dois aspectos: o enunciado do antecedente da norma individual e concreta que analisamos se constitui como fato ao descrever o evento (...) Pensando assim, a natureza da norma individual e concreta, veiculada pelo ato de lançamento tributário, ou pelo ato produzido pelo sujeito passivo para apurar seu débito, nos casos estabelecidos em lei, assumirá a feição significativa de providência constitutiva
} 
Cientes da importância do lançamento no direito tributário, enquanto marco constitutivo do crédito dessa natureza, é possível dizer que se o decurso temporal de cinco anos ocorrer antes do lançamento, é caso de decadência, se depois, prescrição.

O INSS, após a ocorrência do fato gerador, tem o prazo de cinco anos para fazer o lançamento e, por conseguinte, constituir o crédito tributário, sob pena de não mais poder fazê-lo, bem como, formalizado o ato administrativo, tem o mesmo prazo para iniciar um processo de execução contra o sujeito passivo, sob pena de prescrição do seu direito.

O prazo para constituição do crédito tributário por parte do fisco está previsto no inciso I do artigo 173 do CTN, que determina que a contagem do prazo decadencial inicia-se no primeiro dia do exercício seguinte àquele em que 0 lançamento poderia/deveria ter sido efetuado.

Dessa feita, decorrido prazo quinquenal, extingue-se definitivamente o direito de constituição do crédito tributário por parte do ente administrativo fiscal. O lançamento, enquanto ato administrativo, é o único capaz de suspender ou interromper o curso do prazo decadencial, já que inexiste outra previsão no sistema jurídico tributário.

Podemos dizer, então, a título exemplificativo, que o direito da Receita Federal constituir o crédito tributário, cujo fato imponível ocorreu em janeiro de 2010, extingue-se em janeiro de 2016, ou seja, cinco anos após o primeiro dia do exercício seguinte àquele em que ocorreu o fato imponível tributário.

Cumpre-se destacar que, nos casos em que o contribuinte presta a sua declaração por meio da GFIP de alguma forma, o prazo decadencial tem início imediatamente após a ocorrência do fato gerador, nos termos do parágrafo $4^{\circ}$ do artigo 150, e não no ano subsequente, conforme a regra prevista no artigo 173 , ambos do Código Tributário Nacional.

Portanto, é o fato gerador da contribuição social definido em lei, o gatilho que inicia a contagem do prazo decadencial de constituição do crédito tributário e o lançamento é o ato administrativo capaz de interrompê-lo.

Nos termos do artigo 51 da Instrução Normativa n`971, de 2009, inclusive com as alterações trazidas pela Instrução Normativa ${ }^{\circ} 1.453 / 2014$, é a prestação 
de serviço remunerado que constitui o fato gerador da obrigação previdenciária principal, tanto para o empregado, quanto para o empregador.

Cumpre-se destacar que o artigo 52 do mesmo diploma legal dispõe que a ocorrência do fato gerador se dá quando for paga, devida ou creditada a remuneração, o que ocorrer primeiro decorrente da referida prestação de serviço.

Poderia se gerar alguma dúvida em relação à ocorrência do fato gerado da contribuição social decorrente de sentença trabalhista, entretanto, quando da investigação da base de cálculo, verificamos que a contribuição previdenciária decorre da obrigação de pagar, e não do efetivo pagamento. Essa é, inclusive, a disposição prevista no parágrafo $2^{\circ}$ do artigo 43 da Lei $n^{\circ} 8.212 / 91$, que atribui ao momento da prestação do serviço remunerado a ocasião da ocorrência do fato imponível tributário.

É certo, portanto, que o fato gerador e a obrigação tributária dele decorrente são de enorme importância declarativa, na medida em que inúmeras são as implicações que decorrem desse relato histórico, sendo necessário o revestimento linguístico apropriado para subsunção do fato à norma geral e abstrata.

Dessa feita, o fato gerador, enquanto não vertido em linguagem competente, deve ser encarado com um mero evento e a obrigação tributária somente será constituída no consequente normativo de uma norma individual e concreta, em que pese historicamente haver nascido em momento anterior.

Em outras palavras, é o ato administrativo de lançamento ou de autuação pelo descumprimento da obrigação legal tributária que vai fazer incidir a norma ao fato, constituindo o crédito, de modo a revesti-lo de juridicidade e executoriedade, inclusive, para fins de se evitar a sua consumação pelo decurso do prazo decadencial.

No âmbito da Justiça do Trabalho, conforme já mencionamos em outros tópicos, inexiste o procedimento de incidência da norma e constituição do crédito tributário, o qual surge automaticamente em razão da sentença trabalhista.

Essa metodologia, que do ponto de vista da praticidade é excelente, principalmente por primar pela arrecadação, acaba por suscitar inquietações científicas no direito.

Conforme já asseverado, o Inciso I do artigo 173 do Código Tributário Nacional estabelece a forma de contagem do prazo decadencial, o qual se inicia 
no primeiro dia do exercício seguinte àquele em que o lançamento poderia ter sido efetuado. Decorrido esse prazo, extingue-se definitivamente o direito da autoridade administrativa constituir o crédito administrativamente.

Seguindo o corte metodológico para fins de dissecação da incidência normativa, da investigação da base de cálculo, verificamos que a contribuição social destinada ao custeio da seguridade social decorre da obrigação de pagar a remuneração ao trabalhador, e não do efetivo seu pagamento. O parágrafo $2^{\circ}$ do artigo 43 da Lei no 8.213/91 atribui ao momento da prestação do serviço remunerado a ocasião da ocorrência do fato imponível tributário.

Assim, podemos concluir facilmente que o direito/dever da União lançar o crédito decorrente das contribuições sociais executadas na Justiça do Trabalho não surge com o trânsito em julgado da sentença ou com o início execução, mas no exato momento em que a remuneração paga na reclamação trabalhista tornouse devida, ou seja, na ocasião da prestação do trabalho reclamado.

Conforme a regras inseridas no sistema do direito tributário, o lançamento ou o auto de infração são os únicos atos jurídicos capazes de interromper o curso do prazo decadencial. Nenhum outro ato, judicial ou administrativo, tem esse poder.

Portanto, seguindo a lógica traçada no presente estudo, o lançamento tributário, conforme será visto oportunamente, poderia ocorrer no curso da própria reclamação trabalhista, pouco importando o seu resultado final. Os dados produzidos na Justiça do Trabalho e sob a sua sistemática não vinculam outras relações jurídicas decorrentes do mesmo fato, apresentando-se, para fins fiscais e previdenciários, como meras informações probatórias.

Em outras palavras, a Justiça do Trabalho pode atribuir a qualidade de empregado ao reclamante, entretanto, essa decisão não importa na sua automática condição de segurado, muito menos da existência de relação fiscal. Tanto isso é verdade que a Receita e o INSS podem negar efeitos previdenciários aos fatos declarados na sentença trabalhista, à qual a jurisprudência atribui a simples qualidade de início de prova material.

Em razão do exposto, passados mais de seis anos do término do período reclamado, o direito de lançar os créditos tributários decorrentes das obrigações reclamadas estaria decaído, nesse sentido, também já se manifestou o Tribunal Superior do Trabalho (TST), conforme veremos em capítulo adiante ao 
estudarmos as incongruências da sentença trabalhista para fins de execução do crédito tributário. 


\section{EXECUÇÃO FISCAL NA JUSTIÇA DO TRABALHO}

Diante da natureza eminentemente tributária da contribuição social, da metodologia de incidência normativa e constituição do crédito dentro das regras do Sistema Jurídico Tributário, bem como da forma de contagem dos prazos de prescrição e decadência, importante tecer alguns breves comentários acerca de como se dá a introdução da norma jurídica trabalhista, em especial, discorrer sobre a sentença, que é o seu instrumento introdutor, suas variadas formas e os efeitos fiscais decorrentes da declaração de fatos susceptíveis de incidência do tributo destinado ao custeio da previdência.

Será aventada, ainda, neste capítulo a importância da liquidação do julgado trabalhista para os fins arrecadatórios, uma vez que inexistindo o prévio lançamento, é nessa fase preparatória da execução que se fixam a base de cálculo e por consequência o valor exigível forçadamente na Justiça Laboral.

Será abordada, ainda, a questão da prescrição intercorrente do crédito tributário no curso do processo trabalhista e eventual extinção do mesmo em razão do decurso desse prazo, visto que se o intuito da norma foi assegurar a arrecadação, imprescindível que o procedimento não coloque em risco o Sistema da Seguridade Social.

Far-se-á uma crítica do ponto de vista científico da incidência normativa fiscal ao inciso VIII do artigo 114 da Constituição, em razão do caráter sui generis da inserção no mundo jurídico de norma tributária individual e concreta por meio de sentença trabalhista.

Por fim, analisaremos superficialmente a competência da Justiça Federal em concorrência com aquela atribuída à do Trabalho, bem como eventual discussão atinente ao devido processo legal e a ausência de impugnação específica ao crédito tributário, mormente porque ele jamais será constituído por meio de sentença trabalhista.

\subsection{A Sentença no Processo do Trabalho}

Conforme já amplamente discutido, é inegável a natureza jurídica tributária das contribuições destinadas ao custeio da seguridade social, bem como que a execução destas na Justiça do Trabalho depende da preexistência de título executivo trabalhista para prosseguir em caráter acessório. 
A teoria da incidência normativa de Paulo de Barros Carvalho, melhor analisada no item 3.7 deste capítulo, nos ensina que a sentença é considerada um instrumento introdutor de norma individual e concreta no mundo jurídico. Em outras palavras, para ele a sentença pode ser considerada importante fonte de direito, na medida em que compreende por fontes do direito os órgãos credenciados pelo sistema do direito positivo para produzirem normas, bem como a própria atividade por esses órgãos desenvolvida na produção normativa ${ }^{59}$.

O estudo das fontes do direito é de fundamental importância para qualquer investida dogmática sobre o direito positivo, pois só assim o jurista estará munido de conhecimento essencial para o deslinde da grande maioria dos temas obscuros para a ciência do direito e prática forense.

As fontes do direito são acontecimentos do mundo social juridicizados por regras de um sistema jurídico e credenciados a produzir normas jurídicas introdutoras de normas. Podemos chamar esses acontecimentos de atos de enunciação, sendo as normas produzidas os enunciados.

Não é difícil perceber que o sistema de normas, introdutoras e introduzidas, integra o que conhecemos por direito positivo, ao passo que 0 conjunto de fatos, aos quais a ordem jurídica atribuiu teor de juridicidade, se tomados na qualidade de enunciação e não como enunciados, estarão formando o território das fontes do direito posto.

Desse modo, um acontecimento da vida real social será ensejador de eficácia jurídica se, e somente se, estiver previsto em norma válida do sistema, que o descreve em sua hipótese (antecedente normativo), disciplinando o comportamento humano dele irradiado no seu consequente.

A sentença é, portanto, o instrumento pelo qual o juiz de um processo, por ser o agente autorizado pelo sistema jurídico, introduz norma jurídica individual e concreta, por meio de um procedimento legalmente previsto em outra norma, o qual passa a produzir todos os seus efeitos após o trânsito em julgado.

Cada sistema jurídico trará um regramento próprio para que as normas dele decorrentes possam ser introduzidas de forma que sejam consideradas válidas e produzam seus efeitos plenamente.

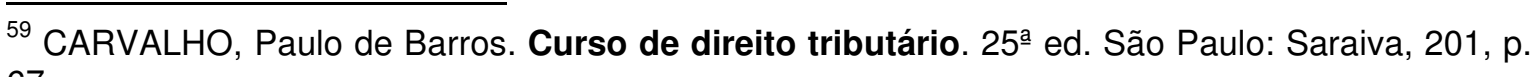
67. 
No processo do trabalho isso não é diferente, na medida em que a Consolidação das Leis do Trabalho e demais normas jurídicas incidentes sobre tal procedimento estabelecem um conjunto de regras aplicáveis a esse sistema, para que o resultado seja a introdução no mundo jurídico, por meio do processo de subsunção, norma individual e concreta válida.

Destaca-se que, ao contrário do processo civil, o trabalhista não prevê uma definição específica para a sentença enquanto instrumento introdutor de norma dele decorrente. Os artigos 831 e 832 da CLT prescrevem genericamente sobre a decisão judicial proferida no caso de infrutífera a tentativa de composição.

Enquanto fonte subsidiária de direito, nos termos do artigo 769 da CLT, é possível a utilização do conceito de sentença previsto no Código de Processo Civil para melhor entendermos esse título executivo.

Lembremos a redação original do parágrafo $1^{\circ}$ do artigo 162 do CPC, esta previa que a sentença seria 0 ato pelo qual o juiz colocaria fim ao processo. Entretanto, durante muitos anos essa definição sofreu duras críticas doutrinárias, na medida em que era dotada de uma impropriedade técnica gritante, pois nem de longe a sentença, enquanto introdutor de norma produzida em primeiro grau, é capaz de colocar fim ao processo judicial, seja no âmbito civil ou do trabalho.

Assim, após a prolação da sentença, a parte sucumbente pode apresentar seu inconformismo dentro do prazo legal por meio do manejo dos recursos legalmente previstos no sistema jurídico a que pertence.

Outrossim, nas ações em que resultar a condenação de uma das partes envolvidas, ainda que a sentença transite em julgado em primeiro grau, o processo deverá prosseguir na fase denominada cumprimento de sentença, conforme previsto nos artigos 475-I e seguintes do Código de Processo Civil, introduzido em 2005 pela Lei 11.232.

Diante dessa sincretude inerente ao processo civil vigente, a própria Lei 11.232/05 também alterou o disposto no parágrafo 1ํ do artigo 162 do Código de Processo Civil, alterando a definição de sentença até então vigente. A redação atual estabelece que a "sentença é o ato do juiz que implica alguma das situações previstas nos arts. 267 e 269 do CPC" 60.

\footnotetext{
60 "A lei não mais define sentença apenas pela finalidade, como previsto no ex-CPC $162 \S 1$ 으, isto é, como ato que extingue o processo, mas sim pelo critério misto do conteúdo e finalidade. De acordo com a nova redação do CPC $162 \S 1^{\circ}$, chega-se a essa definição de sentença: Sentença é
} 
Para Giuseppe Chiovenda ${ }^{61}$, a sentença deve ser conceituada como:

\begin{abstract}
a provisão do juiz que, recebendo ou rejeitando a demanda do autor, afirma a existência ou inexistência de uma vontade concreta de lei que the garanta um bem ou respectivamente a inexistência ou existência de uma vontade de lei que garanta um bem ao réu.
\end{abstract}

Para efeitos do presente trabalho, podemos conceituar a sentença como sendo o suporte físico adequado para a formalização de um ato jurídico, com o qual o juiz, que é autoridade competente e investida de jurisdição pelo Estado ${ }^{62}$, aplica a norma geral e abstrata ao caso concreto, por meio do processo de subsunção, exaurindo a atividade judicante de primeira instância, com ou sem a resolução do mérito.

Enquanto instrumento introdutor, a sentença pode ser dividida em três partes. A primeira, denominada relatório, é aquela na qual o magistrado do processo demonstra o conhecimento das versões dos fatos narrados pelas partes, bem como de tudo o que foi produzido no curso da instrução processual. Pode ser definida como a síntese da demanda que lhe está sendo colocada para apreciação e decisão.

No procedimento sumaríssimo o relatório é dispensado nos termos do artigo 852-I da CLT, que determina apenas que a sentença deve mencionar os elementos de convicção do juízo, com resumo dos fatos relevantes ocorridos em audiência.

A segunda parte da sentença, a fundamentação, decorre da previsão constitucional inserida no inciso IX do artigo $93^{63}$, a qual estabelece que todos os julgamentos emanados dos órgãos do Poder Judiciário deverão ser

o pronunciamento do juiz que contém uma das matérias do CPC 267 ao 269 e que, ao mesmo tempo, extingue o processo ou a fase de conhecimento no primeiro grau de jurisdição." (NERY JÚNIOR, Nelson; NERY, Rosa Maria de Andrade. Código de Processo Civil Comentado. 13 ed. São Paulo: Revista dos Tribunais, 2013, p. 519).

${ }_{61}$ CHIOVENDA, Giuseppe. Instituições de Direito Processual Civil. trad. Paolo Capitanio. Campinas: Bookseller, 1998, p. 198.

${ }^{62}$ ROCCO, Alfredo. La Sentenza Civile. Milano: Giuffrè, 1962, p. 78.

63 "Art. 93. Lei complementar, de iniciativa do Supremo Tribunal Federal, disporá sobre o Estatuto da Magistratura, observados os seguintes princípios: (...) IX todos os julgamentos dos órgãos do Poder Judiciário serão públicos, e fundamentadas todas as decisões, sob pena de nulidade, podendo a lei limitar a presença, em determinados atos, às próprias partes e a seus advogados, ou somente a estes, em casos nos quais a preservação do direito à intimidade do interessado no sigilo não prejudique o interesse público à informação;" 
fundamentados, sob pena de nulidade. Em âmbito infraconstitucional, o artigo 131 do Código de Processo Civil atribui ao juiz o dever de indicar os motivos que formaram o seu convencimento no julgamento dos fatos.

Em que pese não transitar em julgado, a teor do inciso I do artigo 469 do Código de Processo Civil, a fundamentação é de suma importância para garantia da transparência das decisões emanadas do Poder Judiciário. A motivação do decisum, enquanto parte persuasiva ${ }^{64}$ do instrumento, é o que permite com que as partes avaliem a necessidade e conveniência do manejo de recurso às instâncias superiores.

Na parte dispositiva da sentença acontece a materialização do direito em razão da incidência normativa, sendo esta parte que faz a coisa julgada material, abarcando o pedido e a causa de pedir, tal qual expressos na petição inicial e são adotados na fundamentação do decisum, compondo a res judicata ${ }^{65}$.

Humberto Theodoro Junior ${ }^{66}$ assevera que a parte dispositiva da sentença é a que atribui a eficácia da imutabilidade e indiscutibilidade à decisão após o trânsito em julgado, nos termos do artigo 468 do Código de Processo Civil.

Entretanto, o dispositivo não deve ser confundido com a parte final da sentença necessariamente, pois pode ser localizado em qualquer momento onde o magistrado, de alguma forma, tenha resolvido uma questão decorrente da causa de pedir.

Cumpre-se realçar que a coisa julgada material, por ser decorrente da parte dispositiva da sentença, também está adstrita aos limites objetivos

\footnotetext{
64 "(...) a decisão aparece como um sistema de procedimentos regulados em que cada agente age de certo modo porque os demais agentes estão seguros de poder esperar dele um certo comportamento. Não se trata de regularidades lógicos-formais, mas, por assim dizer, ideológicas. O discurso dogmático sobre a decisão não é só um discurso 'informativo' sobre como a decisão deve ocorrer, mas um discurso 'persuasivo' sobre como se faz para que a decisão seja acreditada pelos destinatários. Visa despertar uma atitude de crença. Intenta motivar condutas, embora não se confunda com a eficácia das próprias normas. Por isso a 'verdade' decisória acaba se reduzindo, muitas vezes, à decisão prevalecente, com base na motivação que the dá suporte." (FERRAZ JÚNIOR, Tércio Sampaio. Introdução ao estudo do direito: técnica, decisão, dominação. São Paulo: Atlas, 1994, p. 344).

65 "A coisa julgada está delimitada pelo pedido e pela causa de pedir apresentados na ação de conhecimento, devendo sua execução se processar nos seus exatos limites." (REsp no 882242/ES, Rel. Min. Laurita Vaz, Quinta Turma, DJe 01.06.2009).

66 "É na conjugação dos atos das partes e do juiz que se chega aos contornos objetivos da coisa julgada. São, pois, as pretensões formuladas e respectivas causas de pedir (questões litigiosas) julgadas pelo Judiciário (questões decididas) que se revestirão da eficácia da imutabilidade e indiscutibilidade de que trata o art. 468 do CPC." (in "Notas sobre a sentença, coisa julgada e interpretação", Revista de Processo no 167, ano 34, janeiro de 2009).
} 
decorrentes dos fatos constitutivos narrados e dos pedidos formulados pelas partes no processo ${ }^{67}$, sob pena de julgamento ultra, extra ou infra petita.

No que tange ao processo do trabalho especificamente, existem alguns pontos que obrigatoriamente devem constar do dispositivo da sentença, os quais constam expressamente nos artigos da Consolidação das Leis do Trabalho. O parágrafo $1^{\circ}$ do artigo 832 determina que "quando a decisão concluir pela procedência do pedido, determinará 0 prazo e as condições para o seu cumprimento". Os parágrafos $2^{\circ}$ e $3^{\circ}$ do mesmo dispositivo legal preveem a necessidade de constarem as custas a serem pagas pelo vencido, bem como a natureza jurídica das parcelas constantes da condenação ou do acordo homologado, inclusive o limite da responsabilidade de cada parte pelo recolhimento da contribuição previdenciária, quando for o caso.

Igualmente, a forma da liquidação da sentença, os juros, correção monetária e o valor da condenação que servirá de base para o cálculo das custas e para efeito de depósito recursal devem constar expressamente da parte dispositiva.

Em relação à regra de que o julgamento deve respeitar os limites dos pedidos formulados pelas partes, o processo do trabalho prevê algumas exceções, as quais autorizam, em determinados casos, o julgamento fora dessas balizes.

O artigo 467 da CLT, por exemplo, ao prever que no caso de rescisão de contrato de trabalho, havendo controvérsia sobre o montante das verbas rescisórias, o empregador é obrigado a pagar ao trabalhador, à data do comparecimento à Justiça do Trabalho, a parte incontroversa dessas verbas, sob pena de pagá-las acrescidas de cinquenta por cento, autorizado o julgamento ultra petita.

Da mesma forma, o artigo 496 do mesmo diploma legal permite o julgamento extra petita. Nas lides onde o reclamante está pleiteando a reintegração no posto de trabalho, o magistrado fica autorizado, independentemente de pedido expresso, a determinar o pagamento de

\footnotetext{
67 "A coisa julgada material tem como limites objetivos a lide e as questões pertinentes a esta, que foram decididas no processo. (...) O que individualiza a lide, objetivamente, são o pedido e a causa petendi, isto é, o pedido e o fato constitutivo que fundamenta a pretensão. Portanto, a limitação objetiva da coisa julgada está subordinada aos princípios que regem a identificação dos elementos objetivos da lide." (MARQUES, José Frederico. Manual de Direito Processual Civil. Vol. III, 3르 ed. São Paulo: Saraiva, 1975, p. 237).
} 
indenização em dobro em vez de condenar a empresa na recolocação do empregado.

Na mesma linha, a súmula 211 do Tribunal Superior do Trabalho determina que os juros de mora e a correção monetária devem ser incluídos na liquidação da sentença, ainda que o pedido inicial for omisso nesse ponto.

O próprio parágrafo $3^{\circ}$ do artigo 832 da CLT, ao estabelecer que deva obrigatoriamente constar do dispositivo a parcela de cada parte pelo recolhimento da contribuição previdenciária, indiretamente, autoriza a subsistência de um julgamento extra petita, no caso de não haver constado do pedido autoral.

O comando inserido no artigo supracitado foi inserido no corpo da CLT pela Lei 10.035/00 atende às disposições da Constituição, que determinou a execução de ofício da contribuição social decorrente das sentenças proferidas pela justiça do trabalho.

Seria, no mínimo, estranho dar-se início ao procedimento de execução do referido tributo sem que a obrigação pelo recolhimento deste houvesse constado do título executivo judicial.

Dessa feita, importante manter-se em mente a importância da sentença enquanto suporte físico para a introdução no universo jurídico trabalhista de norma individual e concreta suscetível de ser executada nos exatos limites dos pedidos formulados pelas partes do processo e das exceções a essa regra, as quais se encontram previstas no ordenamento jurídico que regula a matéria.

\subsection{Modalidades de Sentença}

Em função da já mencionada possibilidade de execução acessória das contribuições sociais decorrentes das sentenças proferidas pelos magistrados trabalhistas, importante uma breve análise das modalidades existentes nesse sistema jurídico.

Em primeiro plano, podemos dividir as sentenças em duas categorias gerais nos termos dos artigos 267 e 269 do Código de Processo Civil, as definitivas e as terminativas, em que as primeiras resolvem o mérito da ação e as segundas decorrem de uma extinção sem tal resolução. 
Em relação às decisões terminativas, conforme o magistério de Sérgio Pinto Martins ${ }^{68}$, não se aplica ao processo do trabalho as hipóteses previstas nos incisos VII, IX e X do artigo 267 do CPC. Esse tipo de sentença, em que pese transitar em julgado, não faz coisa julgada material.

Já nas sentenças definitivas, o juiz, após ingressar no mérito da questão, acolhe ou rejeita o pedido formulado pelo autor. Na CLT, encontram referência expressa no parágrafo $1^{\circ}$ do artigo 893 e nos incisos do artigo 895. As sentenças homologatórias de acordo também têm natureza definitiva (art. 831, CLT), na medida em que também só podem ser atacadas por meio de ação rescisória.

As definitivas, por sua vez, podem ser subclassificadas em constitutivas, condenatórias e declaratórias, tudo de acordo com a postulação autoral. Aquelas que, resolvendo o mérito, julgam pela improcedência do pedido, terão sempre a natureza meramente declaratória.

As declaratórias limitam-se a consignar por decisão definitiva a existência ou inexistência de uma relação jurídica alegada por meio de petição inicial. São, por exemplo, as que reconhecem o vínculo empregatício.

Por constitutivas entendem-se aquelas que determinam a criação, modificação ou extinção de uma situação ou relação jurídica incontroversa. É claro que precede a constituição desse direito a declaração de existência deste, de modo que nesse tipo de sentença existem dois momentos naturais, o primeiro declaratório e o segundo no qual se determina que se concretize a modificação declarada.

A sentença que julga procedente a pretensão de rescindir o contrato de trabalho do empregado estável pode ser um exemplo dessa modalidade de decisão na Justiça do Trabalho, uma vez que o vínculo e a estabilidade são fatos jurídicos incontroversos que demandam a sua modificação por meio de decisão proferida pelo magistrado trabalhista.

Nesse diapasão, diante da teoria da incidência normativa utilizada como base para o presente estudo, especificamente relacionada com a produção de normas por meio de sentença, podemos separar o fenômeno da sua aplicação no plano social em três momentos bem especificados.

${ }^{68}$ MARTINS, Sérgio Pinto. Direito Processual do Trabalho. 34를 ed., São Paulo: Atlas, 2013, p. 374. 
No primeiro, são definidos abstratamente os preceitos normativos que regem a sociedade à que pertencem no campo do dever ser, o que se dá por meio da atuação pública monopolizada pelo Estado enquanto órgão legislador. Já no segundo momento, a autoridade competente, no caso o juiz, faz incidir a norma no caso concreto, produzindo uma norma individualizada, baseada na conduta do transgressor da norma geral.

Por fim, após a concretização da fenomenologia da incidência normativa, por meio do processo de subsunção da norma geral ao caso concreto por meio de ação humana, representada pela figura do agente legitimado, que, ao verter em linguagem competente, juridiciza o fato, pode se iniciar o terceiro momento, o da execução dessa norma individualizada.

Diante da acessoriedade executiva das contribuições sociais na Justiça do Trabalho, bem como da importância da análise da eficácia executiva dos julgados produzidos em ambiente trabalhista, emerge a relevância das sentenças definitivas condenatórias.

A complexidade das sentenças condenatórias está no fato de que, conforme asseverado por Liebman ${ }^{69}$, essa espécie de sentença tem dupla função, na medida em que em um primeiro momento declara a existência de um direito previsto no antecedente normativo de uma norma geral abstrata e, em seguida, deixa evidente o seu conteúdo condenatório, decorrente da aplicação das sanções previstas no consequente normativo dessa mesma norma geral e abstrata, a penalização pelo não cumprimento do dever ser.

Em outras palavras, a imposição de uma obrigação à parte vencida é o que distingue a sentença condenatória das demais modalidades, posto que a sua principal característica é a outorga de eficácia jurídica para o início da execução forçada $^{70}$.

\footnotetext{
69 "a sentença condenatória tem duplo conteúdo e dupla função: em primeiro lugar, declara o direito existente - e nisto ela não difere de todas as outras sentenças (função declaratória); e, em segundo lugar faz vigorar para o caso concreto as forças coativas latentes na ordem jurídica, mediante aplicação da sanção adequada ao caso examinado - e nisto reside a sua função específica, que a diferencia das outras sentenças." (LIEBMAN, Enrico Tullio. Processo de Execução. $3^{\underline{a}}$ ed., São Paulo, Saraiva, 1968, p. 16).

70 "É sabido que só a sentença condenatória atribui à parte vencedora o poder de promover ação executória contra o sucumbente. Nenhuma outra sentença é apta a produzir tal efeito. Não o produz decerto, ainda quando reconheça ao autor a titularidade de um crédito em face do réu, a sentença meramente declaratória: tornando-se exigível o crédito declarado, e não se dispondo a satisfazê-lo o devedor, cumpre ao credor voltar a ajuízo com ação condenatória, e apenas a nova sentença que lhe julgue procedente o pedido constituirá em seu favor título hábil para a execução
} 
No processo do trabalho, podemos citar o exemplo da sentença que ao declarar a existência do vínculo empregatício, determina o pagamento das verbas decorrentes desse reconhecimento. É, portanto, declaratória e condenatória ao mesmo tempo. Por outro lado, a sentença que reconhece a equiparação salarial e manda pagar as diferenças resultantes da equiparação é constitutiva e condenatória.

\subsection{A Fixação do Valor do Tributo}

Constituída a obrigação trabalhista por meio de decisão irrecorrível, a qual, sob a ótica da incidência normativa, ingressou no mundo jurídico por meio de instrumento introdutor legítimo, produzido por autoridade competente, que ao aplicar a regra geral ao caso concreto, fez emergir a norma individual, passemos a verificar como se dá a efetivação desse direito.

A execução de ofício da obrigação tributária decorrente dos fatos juridicizados no âmbito da Justiça do Trabalho depende da preexistência de procedimento de execução trabalhista.

Diante de uma decisão condenatória transitada em julgado ou do inadimplemento de um acordo homologado por sentença, cumpre ao magistrado trabalhista dar início à fase de execução, contudo, não sem antes de certificar-se da liquidação do julgado. O termo mais correto seria a liquidação da obrigação contida na sentença, conforme o magistério de Sérgio Pinto Martins ${ }^{71}$.

A liquidação, fase antecedente do procedimento de execução, é de fundamental importância para fins de execução de ofício das contribuições sociais decorrentes de fatos jurídicos constituídos por sentença trabalhista, na medida em que antes de se determinar o recolhimento dessas parcelas fiscais, cabe ao juiz da execução delimitar a base de cálculo para fins de incidência do tributo.

Tal procedimento pode se dar por arbitramento, artigos ou cálculos, tudo de acordo com o pedido autoral, a prova produzida na fase de conhecimento e a possibilidade de demonstrar por meio de prova a quantificação decorrente de determinado fato juridicizado pelo magistrado trabalhista. Independentemente da

forçada." (MOREIRA, José Carlos Barbosa. Reflexões Críticas sobre uma teoria da condenação civil. In Temas de Direito Processual Civil. 1a Série, São Paulo, Saraiva, 1977, p. 72).

${ }^{71}$ MARTINS, Sérgio Pinto. Direito Processual do Trabalho. 34를 ed. São Paulo: Atlas, 2013, p. 739. 
forma como se mensurará a extensão econômica de determinado fato jurídico reconhecido por sentença, a liquidação é de suma importância para fins fiscais.

O parágrafo $3^{\circ}$ do artigo 884 da Consolidação das Leis do Trabalho, mesmo não havendo o que se falar em recorribilidade desse tipo de determinação $0^{72}$, outorga natureza de sentença à decisão que julga a liquidação da obrigação, homologando um ou outro cálculo.

Sérgio Pinto Martins ${ }^{73}$ atribui efeito declaratório a essa decisão, visto que apenas complementa o título executivo judicial constituído na fase de conhecimento, tratando-se de uma preparação para que seja dado início à execução propriamente dita.

Definido o quantum debeatur exigível forçadamente em fase própria, dáse início à execução, a qual deve sempre ser funda em justo título.

Iniciada a execução da condenação de ordem trabalhista, dá-se início por acessoriedade à execução das contribuições sociais decorrentes do mesmo julgado.

\subsection{Execução da Contribuição Previdenciária}

Conforme vimos em capítulo anterior, a inserção por meio das Emendas Constitucionais $n^{\text {os }} 20 / 98$ e 45/04, que culminou com a redação atual do inciso VIII do artigo 114 da Constituição, acabou por criar uma execução incidental que tem como beneficiário quem não era parte no processo de conhecimento e, também, não o é no executivo trabalhista.

Em que pese fugir da lógica de incidência da norma jurídica tributária, a contribuição executada na Justiça do Trabalho não necessita de lançamento, auto de infração ou inscrição na dívida ativa para fins de execução.

$\mathrm{Na}$ visão do constituinte, toda essa fase, crucial para garantia do devido processo legal, ampla defesa e contraditório no procedimento tributário em geral, pode ser substituída pela participação da União após o início de ofício da cobrança desses valores.

\footnotetext{
${ }^{72} \mathrm{O}$ parágrafo $3^{\circ}$ do artigo 884 da CLT determina que a sentença somente pode ser impugnada por meio de embargos do devedor ou impugnação do credor, o que pode fazer equiparar a sentença que homologa a liquidação a uma decisão interlocutória.

${ }_{73}$ MARTINS, Sérgio Pinto. Direito Processual do Trabalho. 34ª ed., São Paulo: Atlas, 2013, p. 749.
} 
Com o advento da Lei $\mathrm{n}^{\circ} 10.035 / 00$, que alterou diversos dispositivos da Consolidação das Leis do Trabalho, ficou claro que a execução dessas contribuições seguiria o ordenamento jurídico trabalhista, sendo apenas supridas as omissões pelas regras que regem o processo dos executivos fiscais para a cobrança judicial da dívida ativa da Fazenda Pública Federal (Lei $\left.{ }^{\circ} 6.830 / 80\right)^{74}$.

A referida lei que dispõe sobre a cobrança judicial da Dívida Ativa da Fazenda Pública trata da execução fundada em título executivo extrajudicial, sendo de competência da Justiça Federal. Em contrapartida, a execução decorrente de sentença trabalhista, diante de sua "eficácia natural perante terceiros", é de competência exclusiva da Justiça do Trabalho.

Assim, se é o juiz do trabalho que tem a competência para executar essa contribuição, ele também deve atrair pra si a respectiva jurisdição para definir sobre quais verbas incidirá o tributo, nos termos do artigo 28 da Lei $n^{\circ} 8.212 / 91$.

Nos casos em que a sentença for meramente homologatória de acordo, existe a exceção à regra da manifestação do fisco só em fase de liquidação, na medida em que a composição entre particulares não pode prejudicar terceiro diretamente interessado no desfecho da lide.

O termo de conciliação lavrado em audiência ou a homologação de acordo extrapauta produzirá seus efeitos de decisão irrecorrível apenas para as partes. O parágrafo único do artigo 831 da Consolidação das Leis do Trabalho dispõe que o termo de conciliação que for lavrado valerá como decisão irrecorrível, salvo para a Previdência Social quanto às contribuições que lhe forem devidas.

Por se tratar de questão de natureza privada, as partes gozam do direito de transigir sobre as verbas e demais cominações trabalhistas, inclusive em fase de execução, porém, essa composição não vincula à União. O artigo 844 do Código Civil estabelece que a transação não aproveita nem prejudica senão aos que nela intervieram, ainda que diga respeito à coisa indispensável.

Desse modo, as partes não podem transigir sobre crédito que não lhes pertence, não podem dispor sobre direito público de terceiro, no caso, da União. A parte só pode renunciar àquilo que lhe integra o patrimônio.

\footnotetext{
74 "CLT Art. 889 - Aos trâmites e incidentes do processo da execução são aplicáveis, naquilo em que não contravierem ao presente Título, os preceitos que regem o processo dos executivos fiscais para a cobrança judicial da dívida ativa da Fazenda Pública Federal."
} 
Em razão desse dispositivo, inserido pela Lei 10.035/00, mesmo nos casos de composição, a União tem legitimidade ativa, enquanto faculdade, para recorrer da decisão homologatória, entretanto, a objeto recursal será limitado às contribuições decorrentes desse acordo.

A legislação trabalhista não atribui a mesma legitimidade à União nos casos de decisões de mérito, a despeito de isso ser uma grande contradição, uma vez que, admitida a sua condição de terceiro interessado na lide, a mesma poderia manejar o recurso ordinário ou embargos de declaração das sentenças definitivas na fase de conhecimento, com fundamento no artigo 499 do Código de Processo Civil.

O interesse recursal da União nos casos de composição resta configurado e delimitado exclusivamente na tentativa de se evitar que na homologação se consignem como indenizatórias verbas nitidamente de natureza salarial, dessa forma, otimizando-se a arrecadação e evitando-se a sonegação fiscal avalizada por decisão judicial ${ }^{75}$.

E para facilitação dessa fiscalização, é que se exige a discriminação da natureza jurídica das parcelas que compõem os acordos e condenações ${ }^{76}$, o parágrafo primeiro do artigo 43 da Lei 8.212/91 prevê, ainda, que nos casos em que não figurarem, discriminadamente, as parcelas legais relativas às contribuições sociais, estas incidirão sobre o valor total apurado em liquidação de sentença ou sobre o valor do acordo homologado.

Para cumprimento da determinação legal, o recurso cabível por parte da União para discutir uma decisão que homologa o acordo em âmbito trabalhista é o ordinário, que deverá ser julgado pelo Pleno do Tribunal Regional do Trabalho a que estiver vinculado o juiz de primeiro grau.

Destaca-se o fato de que o parágrafo 3 o do artigo 764 da CLT garante às partes 0 direito de fazer acordo a qualquer momento, mas não podem alterar a natureza das verbas deferidas na sentença ou modificar o fato gerador da contribuição social já declarada por sentença.

\footnotetext{
75 "O objetivo do recurso será evitar que o juiz homologue todas as verbas como indenizatórias, quando, na verdade, a pretensão compreende verbas salariais." (MARTINS, Sérgio Pinto. Comentários à CLT. 17ª ed. São Paulo: Atlas, 2013, p. 891).

76 "CLT Art. 832 (...) § 30 As decisões cognitivas ou homologatórias deverão sempre indicar a natureza jurídica das parcelas constantes da condenação ou do acordo homologado, inclusive o limite de responsabilidade de cada parte pelo recolhimento da contribuição previdenciária, se for o caso."
} 
Após o trânsito em julgado da sentença ou após a elaboração dos cálculos de liquidação, não poderá eventual acordo prejudicar os créditos da União ${ }^{77}$.

Os tribunais, quando instados a se manifestar sobre o tema, têm apresentado entendimento no sentido de que a conciliação celebrada na fase de execução substitui a sentença de conhecimento, constituindo novo título executivo, devendo incidir a contribuição previdenciária sobre os valores objetos de acordo homologado ${ }^{78}$.

Para defesa dessa posição, baseiam-se no princípio da conciliação que norteia o processo do trabalho e está inserido no artigo 764 da CLT, em razão disso o acordo celebrado após o trânsito em julgado da sentença não resulta em afronta à coisa julgada.

Para justificar esse tipo de julgado, o Tribunal Superior do Trabalho se apoia na ideia de que da literalidade da norma constitucional inserida no inciso I, alínea "a" do artigo 195 da Constituição se extrai a conclusão de que a incidência da contribuição social somente ocorre quando forem efetivamente constituídos em favor do trabalhador os rendimentos decorrentes do labor prestado por ele, e não na data em que ocorreu a prestação dos serviços. Assim, diante do caráter nitidamente acessório do encargo previdenciário no âmbito da Justiça do Trabalho, a contribuição previdenciária surge como efeito anexo da sentença ou do acordo homologado judicialmente.

O parágrafo $6^{\circ}$ do artigo 832 da CLT dispõe que o acordo celebrado após o trânsito em julgado da sentença não deve prejudicar os créditos da União. Em contrapartida, o parágrafo $5^{\circ}$ do artigo 43 da Lei 8.212/91 determina que, na hipótese de acordo celebrado após ter sido proferida decisão de mérito, a contribuição será calculada com base no valor do acordo.

\footnotetext{
77 "CLT Art. 832 (...) $\S 6^{\circ} \mathrm{O}$ acordo celebrado após o trânsito em julgado da sentença ou após a elaboração dos cálculos de liquidação de sentença não prejudicará os créditos da União."

78 "ACORDO CELEBRADO APÓS O TRÂNSITO EM JULGADO DA DECISÃO. FATO GERADOR DA CONTRIBUIÇÃO PREVIDENCIÁRIA. O acordo celebrado após o trânsito em julgado da sentença não resulta em afronta à coisa julgada. O processo do trabalho é regido pelo princípio da conciliação, presente no art. 764 da CLT. Assim, a conciliação celebrada na fase de execução substitui a sentença de conhecimento, constituindo novo título executivo, devendo incidir a contribuição previdenciária sobre os valores objeto de acordo homologado, excetuadas as parcelas de natureza indenizatória, consoante preconiza a Súmula 368, item I, desta Corte. Recurso de Revista de que não se conhece." (TST - RR: 12500332005502036112500 33.2005.5.02.0361, Relator: João Batista Brito Pereira, Data de Julgamento: 31/8/2011, 5 a Turma, Data de Publicação: DEJT 16/9/2011).
} 
O posicionamento adotado pelo Tribunal Superior do Trabalho por meio da Orientação Jurisprudencial n 376 da Seção de Dissídios Individuais é de que mesmo os acordos celebrados após o trânsito em julgado da sentença de mérito prevalecerão como base de cálculo das contribuições previdenciárias ${ }^{79}$.

A sistemática de indicação da natureza jurídica das parcelas que compõem as decisões homologatórias também serve para as decisões cognitivas, as chamadas sentenças de mérito. Sérgio Pinto Martins ${ }^{80}$ defende que dificilmente o magistrado terá condições de indicar a natureza jurídica de todas as verbas, se salarial ou indenizatória, para fins previdenciários, na medida em que deve estar assoberbado pela obrigação de decidir a questão trabalhista que the posta à apreciação, mesmo sendo-lhe, também, obrigação pensar no crédito da União por imposição constitucional.

Ainda, segundo o doutrinador, seria lícita a homologação da transação ou a atribuição por meio de decisão cognitiva do estabelecimento de responsabilidade pela retenção e recolhimento das contribuições sociais, bem como a efetivação do acordo, por meio do qual se transfere para uma das partes, no caso o empregador, o ônus financeiro do pagamento da integralidade do tributo, inclusive a parte que caberia ao empregado.

Cumpre-se destacar que, no caso de homologação de acordo, a União só deve ser intimada quanto às parcelas indenizatórias, e a possibilidade de discussão por meio de recurso está adstrita às parcelas dessa natureza.

Importante frisar que, até o presente momento, não há o que se falar em execução da contribuição social propriamente dita, na medida em que esta, conforme já amplamente demonstrado, só terá início com o procedimento de execução da condenação trabalhista, da qual será acessória.

Dispõe o artigo 876 da Consolidação das Leis do Trabalho que serão executados nos termos do Capítulo $\mathrm{V}$ as decisões passadas em julgado ou das quais não tenha havido recurso com efeito suspensivo; os acordos, quando não cumpridos; e os termos de ajuste de conduta firmados perante o Ministério

79 "376. CONTRIBUIÇÃO PREVIDENCIÁRIA. ACORDO HOMOLOGADO EM JUÍZO APÓS O TRÂNSITO EM JULGADO DA SENTENÇA CONDENATÓRIA. INCIDÊNCIA SOBRE O VALOR HOMOLOGADO." (DEJT divulgado em 19, 20 e 22/4/2010) É devida a contribuição previdenciária sobre o valor do acordo celebrado e homologado após o trânsito em julgado de decisão judicial, respeitada a proporcionalidade de valores entre as parcelas de natureza salarial e indenizatória deferidas na decisão condenatória e as parcelas objeto do acordo.

${ }^{80}$ MARTINS, Sérgio Pinto. Direito Processual do Trabalho. 34ª ed., São Paulo: Atlas, 2013, p. 805. 
Público do Trabalho e os termos de conciliação firmados perante as Comissões de Conciliação Prévia.

Por sua vez, o parágrafo único do referido dispositivo prevê expressamente acessoriedade na execução das contribuições sociais, ao estabelecer que devem ser executadas ex officio as contribuições sociais devidas em decorrência de decisão proferida pelos Juízes e Tribunais do Trabalho, resultantes de condenação ou homologação de acordo, inclusive sobre os salários pagos durante o período contratual reconhecido.

$\mathrm{Na}$ contramão do texto constitucional, a redação dada pela Lei 11.457/07 condiciona o início de ofício da execução previdenciária à existência de uma sentença definitiva condenatória ou homologatória de acordo. A Constituição não prevê tal limitação na redação do inciso VIII do artigo 114, o que nos leva a crer que a real intenção do constituinte foi que a execução das verbas de natureza fiscal se desse mesmo no caso de ausência de condenação trabalhista.

Em outras palavras, o legislador infraconstitucional criou uma regra de acessoriedade na execução das contribuições sociais em desacordo com a previsão inserida na Constituição. Entretanto, esse é o entendimento consolidado no Supremo Tribunal Federal ${ }^{81}$.

Destaca-se aqui que o juiz do trabalho apenas impulsiona a execução fiscal, pois não é parte do processo para promovê-la. O artigo 878-A da CLT possibilita ao devedor o pagamento imediato da parte que entender devida à Previdência Social, sem prejuízo da cobrança de eventuais diferenças encontradas na execução ex officio.

Em tópico anterior viu-se a importância da liquidação dos julgados para fins de início à execução. Nessa esteira, o legislador ordinário determinou que a liquidação devesse abranger, também, o cálculo das contribuições previdenciárias devidas $\left(\$ 1^{\circ}-\mathrm{A}\right.$ do art.879 da CLT). Portanto, ao intimar as partes para apresentação e manifestação dos cálculos de liquidação, o magistrado deve assegurar que estes abarquem as parcelas devidas à título de tributo previdenciário.

Encerrada a discussão entre as partes do processo, que poderão apresentar seus cálculos, ou após a elaboração dos cálculos pelos órgãos

${ }^{81}$ RE 569.056, j. 11-9-08, Rel. Min. Menezes Direito, DJU 12-12-08. 
auxiliares da Justiça do Trabalho (e.g. contadoria), o juiz deve intimar a União para se manifestar no prazo de dez dias, sob pena de preclusão.

A discordância quanto aos valores apresentados para fins tributários somente poderão ser manejados por meio de impugnação à eventual sentença de homologação de cálculos, se o fisco houver se manifestado oportunamente antes, nos termos do parágrafo $3^{\circ}$ do artigo 879 da CLT.

Homologados os cálculos e requerido o início da execução, nos termos do artigo 880 da $\mathrm{CLT}^{82}$, dar-se-á de fato início à atividade judicial visando à garantia de quitação dos créditos trabalhista e fiscal.

O magistrado da execução mandará expedir mandado de citação do executado, a fim de que cumpra a decisão ou o acordo, no prazo de 48 horas ${ }^{83}$, inclusive com o recolhimento de contribuições sociais devidas à União, e não o fazendo deverá ser determinada a penhora de bens.

Recebida a citação, o artigo 882 da CLT estabelece que a parte que está sendo executada e pretender discutir a execução por meios de embargos do devedor deverá garantir o juízo por meio do depósito ou nomeação de bens à penhora, que possam cobrir o valor atualizado da condenação liquidada, incluída a parcela decorrente da contribuição social, respeitada a ordem de preferência do artigo 655 do Código de Processo Civil.

Como visto, no caso de inércia do executado, o magistrado deve determinar a penhora de bens, tantos quantos baste ao pagamento da importância da condenação, incluída a parcela fiscal, acrescida de custas e juros de mora.

A norma trabalhista prevê que tanto a impugnação da União, credor previdenciário, quanto eventuais embargos opostos pelo devedor, devem ser julgados na mesma sentença ( $\S 4^{\circ}$ do art. 884 da CLT), em benefício do empregado, que é o credor trabalhista. Não há o que se falar em remessa de ofício neste caso, na medida em que o INSS não foi condenado para que haja a

\footnotetext{
82 "Art. 880. Requerida a execução, o juiz ou presidente do tribunal mandará expedir mandado de citação do executado, a fim de que cumpra a decisão ou o acordo no prazo, pelo modo e sob as cominações estabelecidas ou, quando se tratar de pagamento em dinheiro, inclusive de contribuições sociais devidas à União, para que o faça em 48 (quarenta e oito) horas ou garanta a execução, sob pena de penhora."

${ }^{83}$ Não se aplica a regra inserida no art. $8^{\circ}$ da Lei $6.830 / 80$, a qual prevê que o executado será citado para, no prazo de 5 (cinco) dias, pagar a dívida com os juros e multa de mora e encargos indicados na Certidão de Dívida Ativa ou garantir a execução.
} 
incidência do inciso V do artigo $1^{\circ}$ do Decreto-lei $779 / 69$ ou do inciso II do artigo 475 do Código de Processo Civil.

O recolhimento das contribuições sociais devidas em decorrência das sentenças trabalhistas transitadas em julgado deve ser realizado por meio de documento de arrecadação da Previdência Social, fazendo-se constar da guia o número do processo, nos termos do artigo 889-A da CLT.

No caso de concessão de parcelamento pela Secretaria da Receita Federal, o executado deve juntar no processo o documento que comprove tal ajuste. Nesse caso, a execução do tributo ficará suspensa até a quitação, prosseguindo apenas a execução principal, referente à condenação trabalhista.

O parágrafo $2^{\circ}$ do artigo suprarreferido prevê a manutenção de comunicação mensal entre as Varas do Trabalho e a Secretaria da Receita Federal, em que a primeira tem o dever de informar sobre os recolhimentos efetivados nos autos que tramitam sob sua jurisdição.

Essa obrigação, criada para fins de facilitação na arrecadação, ratifica a ideia de que a inserção da competência executória fiscal da Justiça do Trabalho avilta a dignidade do magistrado trabalhista, que parece haver se transformado em verdadeiro serventuário do fisco federal. O correto seria que a União diligenciasse nos autos para verificação do cumprimento da obrigação tributária e, se fosse o caso, promovesse as medidas necessárias para satisfação de seu crédito, ao contrário disso, criou-se uma obrigação de informação, a qual assoberba ainda mais o aparato judicial.

O parágrafo $8^{\circ}$ do artigo 897 prevê a interposição de agravo de petição enquanto recurso cabível da decisão que julgar os embargos do devedor ou a impugnação. Assim, se a discussão versar apenas sobre as contribuições sociais, a execução da condenação trabalhista prosseguirá, sendo remetidas ao Tribunal apenas as cópias das peças necessárias para a apreciação do recurso, que será autuado em apartado.

Da decisão do juízo ad quem poderá ser interposto recurso de revista ao Tribunal Superior do Trabalho, limitada à discussão à violação direta e literal de norma da Constituição ${ }^{84}$.

\footnotetext{
84 "Art. 896 - Cabe Recurso de Revista para Turma do Tribunal Superior do Trabalho das decisões proferidas em grau de recurso ordinário, em dissídio individual, pelos Tribunais Regionais do Trabalho, quando: (...) $\S 2^{\circ}$ Das decisões proferidas pelos Tribunais Regionais do Trabalho ou por
} 
Finalizada a tramitação de todos os recursos cabíveis, sendo necessário levar os bens do devedor a leilão para satisfação da condenação trabalhista e da sua decorrência fiscal, seguir-se-á a ordem de preferência estabelecida pelo artigo 186 do Código Tributário Nacional, o qual estabelece que o crédito tributário prefere a qualquer outro, seja qual for sua natureza ou o tempo de sua constituição, ressalvados os créditos decorrentes da legislação do trabalho ou do acidente de trabalho. Em resumo, quitada a obrigação trabalhista, se sobrar algum numerário, o mesmo será utilizado para pagamento do débito fiscal.

\subsection{A Prescrição Tributária Intercorrente no Processo do Trabalho}

A prescrição, conforme analisada em capítulo próprio, é a perda do direito de ação ocasionada pelo decurso do prazo previsto em lei em razão da inércia do titular no exercício de seu direito. Por sua vez, a prescrição intercorrente é espécie prescricional que tem como termo inicial de sua contagem a citação, sendo ocasionada pela paralisação do processo por muito tempo. Nessa modalidade, o curso do prazo prescricional, antes interrompido pelo ajuizamento da ação trabalhista, recomeça do início.

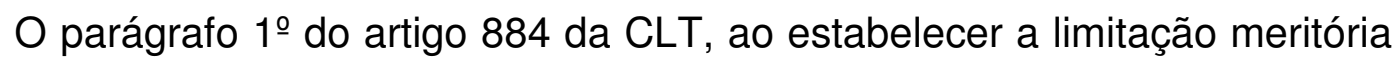
dos embargos do devedor, admite a arguição de prescrição na fase de execução, o que leva a crer que a intercorrente também poderia integrar o petitório do devedor, na medida em que a segunda se trata de espécie da primeira (quem pode o mais, pode o menos).

O Supremo Tribunal Federal pacificou o entendimento na Súmula 150, no sentido de que prescreve a execução no mesmo prazo que a ação, bem como que se admite, igualmente, no direito trabalhista a arguição de prescrição intercorrente ${ }^{85}$.

Em relação ao crédito tributário passível de execução ex officio na Justiça do Trabalho, para fins de contagem de eventual prazo de prescrição intercorrente,

suas Turmas, em execução de sentença, inclusive em processo incidente de embargos de terceiro, não caberá Recurso de Revista, salvo na hipótese de ofensa direta e literal de norma da Constituição Federal."

85 "STF Súmula no 327 - 13/12/1963 - Súmula da Jurisprudência Predominante do Supremo Tribunal Federal - Anexo ao Regimento Interno. Edição: Imprensa Nacional, 1964, p. 145. Direito Trabalhista - Admissibilidade - Prescrição Intercorrente. $O$ direito trabalhista admite a prescrição intercorrente." 
importante observar a previsão do artigo 40 da Lei $n^{\circ} 6.830 / 80$, que determina a suspensão do curso da execução enquanto não for localizado o devedor ou bens sobre os quais possa recair a penhora e que, nesses casos, não correrá o prazo de prescrição.

Entretanto, conforme bem asseverado por Sérgio Pinto Martins ${ }^{86}$, o referido dispositivo não se aplica para a execução da contribuição social na Justiça do Trabalho, uma vez que inexiste a inscrição na dívida ativa que justifique a incidência da norma inserida na Lei $n^{\circ} 6.830 / 80$. Ademais, inexiste qualquer omissão na CLT que justifique a aplicação subsidiária de outro diploma legal.

A suspensão processual ocorrerá sempre que verificada alguma das hipóteses previstas nos artigos 265 e 791 do Código de Processo Civil, tratandose de uma situação juridicamente prevista no ordenamento e, nesse período, o processo, apesar de não poder ser extinto, permanece paralisado em razão da impossibilidade da parte de promover qualquer ato. Dessa feita, considerando os efeitos da suspensão processual, não deve fluir o prazo de prescrição intercorrente durante esse momento processual.

O Tribunal Superior do Trabalho, por meio da Súmula 114, consolidou o entendimento de que a prescrição intercorrente não se aplicaria em ambiente de jurisdição trabalhista. Contudo, conforme vimos anteriormente, esse entendimento vai de encontro ao posicionamento do Supremo Tribunal Federal que, desde 1963, aplica a regra de prescrição intercorrente no processo trabalhista com base na Súmula 327.

Em razão dessa divergência de entendimentos, instalou-se no Direito Processual do Trabalho uma verdadeira guerra doutrinário-jurisprudencial acerca da possibilidade de aplicação desse instituto.

Podemos até argumentar que a outorga de competência de impulso oficial ao magistrado trabalhista prevista nos artigos 765 e 878 da Consolidação das Leis do Trabalho causaria óbice à aplicabilidade da prescrição intercorrente. Entretanto, é certo que mesmo diante da movimentação de ofício do juiz do trabalho na fase de execução, certos atos podem ser de competência exclusiva da parte, que em permanecendo inerte por sua própria liberalidade, não pode ser

\footnotetext{
${ }^{86}$ MARTINS, Sérgio Pinto. Execução da Contribuição Previdenciária na Justiça do Trabalho. 3 a ed., São Paulo: Atlas, 2008, p. 94.
} 
beneficiada com a tramitação ad aeternum da medida judicial. Isso vai de encontro a qualquer interpretação do princípio da segurança jurídica.

Nesse sentido, a jurisprudência mais moderna produzida pelos Tribunais Regionais do Trabalho $^{87}$ vai ao encontro da possibilidade de aplicação excepcional do instituto prescricional intercorrente de acordo com o caso concreto. Não obstante o artigo 878 da CLT dispor expressamente que a execução pode ser promovida por qualquer interessado, ou de ofício pelo próprio juiz da causa, nos casos em que ficar demonstrado o total desinteresse da parte em oportunizar os meios eficazes de alcançar o seu crédito, deixando de praticar atos que thes são exclusivos, não se deve aplicar a hipótese do referido dispositivo que autoriza o impulso oficial.

O entendimento nesse tipo de situação de inércia do exequente por mais de 6 anos consubstancia uma exceção ao entendimento contido na Súmula 114 do Tribunal Superior do Trabalho, autorizando, destarte, a decretação da prescrição intercorrente no curso da execução trabalhista. Inclusive, no que pertine à contribuição social, aplicando-se, em caráter de extrema exceção, subsidiariamente, o parágrafo 4ํำ do artigo 40 da Lei de Execução Fiscal ${ }^{88}$.

Não podemos deixar de considerar o fato de que o Supremo Tribunal Federal, na sua condição de guardião da Constituição e, portanto, pilar do Estado Democrático de Direito, sustenta a aplicabilidade da prescrição intercorrente, também, nas lides trabalhistas. Pensar o contrário seria o mesmo que admitir a existência de uma lide perpétua.

Interpretando sistematicamente 0 ordenamento jurídico trabalhista, podemos extrair do texto do parágrafo $1^{\circ}$ do artigo 884 da CLT a previsão da autorização de aplicação da prescrição intercorrente em sede execução, na medida em que prevê a hipótese de arguição da prescrição enquanto fundamento de procedência dos embargos do devedor.

\footnotetext{
87“PRESCRIÇÃO INTERCORRENTE. RECONHECIMENTO DE OFÍCIO. INÉRCIA DO EXEQUENTE POR 4 (QUATRO) ANOS. EXCECCÃO À SÚMULA 114 DO TST. INAPLICABILIDADE DO ART. 878 DA CLT. PROVIDÊNNCIA QUE COMPETIA À PARTE. A situação narrada nos autos, inércia do exequente, por 6(seis) anos, período em que os autos permaneceram no arquivo sem qualquer manifestação do maior interessado, consubstancia exceção ao entendimento contido na Súmula 114 do C. TST e torna inaplicável o art. 878 da CLT por se tratar de providência que competia à parte e não de impulso oficial." (TRT2 - Agravo de Petição - 8ªT. Proc. n 0094200-13.2006.5.02.0291. Rel. Silvia Almeida Prado. 9/12/2014).

88 "§ 40 Se da decisão que ordenar o arquivamento tiver decorrido o prazo prescricional, o juiz, depois de ouvida a Fazenda Pública, poderá, de ofício, reconhecer a prescrição intercorrente e decretá-la de imediato."
} 
Ora, é muito mais lógica a arguição da intercorrente na fase de execução, uma vez que a prescrição decorrente do transcurso do prazo até o ato citatório já haveria de ou deveria ter sido suscitada e apreciada na fase de conhecimento. Até mesmo porque a redação atual do parágrafo $5^{\circ}$ do artigo 219 do Código de Processo Civil prevê expressamente ser dever de o magistrado declarar de ofício a prescrição.

No que tange o prazo, nos termos da Súmula 150 do Supremo Tribunal Federal, deve-se obedecer na execução o mesmo tempo prescricional da ação. Conforme vimos em capítulo anterior, em razão da natureza jurídica do crédito previdenciário, é necessário aplicar a previsão do Código Tributário Nacional, o qual estabelece, no artigo 174, a regra de prescrição quinquenal do tributo.

Posto isso, por meio da interpretação do ordenamento jurídico empregado ao tema sistematicamente, a prescrição intercorrente parece ter plena aplicabilidade dentro do processo trabalho, em especial na fase de execução.

Portanto, se paralisada a ação por inércia da parte interessada, seja na fase de cognição ou na execução, decorrido o prazo prescricional de cinco anos deve-se operar prescrição intercorrente, a qual o juiz do trabalho tem o dever legal de reconhecer, inclusive, de ofício.

\subsection{Os Efeitos Fiscais}

Importante frisar que, para fins de incidência da contribuição social nas ações trabalhistas, não se denota da redação do caput do artigo 43 da Lei n 8.212/91 qualquer menção à necessidade de extinção do processo para que isso ocorra.

O dispositivo, pertencente ao sistema jurídico de arrecadação fiscal previdenciária, em sua atual redação, dispõe que a incidência tributária se dá sobre o pagamento de direitos sujeitos à contribuição previdenciária em sede de ação trabalhista, sendo obrigação do magistrado a determinação do seu imediato recolhimento.

Diante disso, toda e qualquer parcela sujeita à incidência das contribuições sociais previstas nos incisos I, "a" e II do artigo 195 da Constituição devem fazer parte da execução de ofício na Justiça do Trabalho, na medida em que, por expressa autorização constitucional, a norma jurídica tributária incide 
automaticamente quando reconhecidas em processo do trabalho verbas dessa natureza.

A parcela devida pelo empregado sobre a sua remuneração, nos termos da Lei de Custeio e Regulamento da Previdência, deve ser descontada e recolhida pelo empregador. Esse é o entendimento do Tribunal Superior do Trabalho, que editou a Súmula $368^{89}$, a qual, em seu inciso III determina que se tratando de descontos previdenciários, o critério de apuração encontra-se disciplinado no parágrafo $4^{\circ}$ do artigo 276 do Decreto 3.048/99.

A contribuição do empregado, no caso de ações trabalhistas, deve, portanto, ser calculada mês a mês, aplicando-se as alíquotas previstas no artigo 198 do referido Decreto, observado o limite máximo do salário de contribuição.

A responsabilidade tributária permanece com o empregador, que deve fazer a retenção e o recolhimento da parcela devida pelo empregado, mas o ônus financeiro decorrente do pagamento da contribuição social não deve ser transferido.

Por se tratar de tributo, importante para fins arrecadatórios, a delimitação do fato gerador da contribuição social decorrente de sentença trabalhista. Nesse ponto, tanto o dispositivo constitucional, quanto a Lei de Custeio, são extremante claros, na medida em que o primeiro faz menção expressa ao pagamento de acréscimos legais, o que só se justifica se for observado o critério de competência.

Já o inciso I do artigo 22 da Lei $n^{\circ} 8.212 / 91$ estabelece a incidência de contribuição sobre a remuneração, paga, devida ou creditada. Conforme o

\footnotetext{
89 “DESCONTOS PREVIDENCIÁRIOS E FISCAIS. COMPETÊNCIA. RESPONSABILIDADE PELO PAGAMENTO. FORMA DE CÁLCULO (redação do item II alterada na sessão do Tribunal Pleno realizada em 16/4/2012) - Res. 181/2012, DEJT divulgado em 19, 20 e 23/4/2012.

I - A Justiça do Trabalho é competente para determinar o recolhimento das contribuições fiscais. A competência da Justiça do Trabalho, quanto à execução das contribuições previdenciárias, limitase às sentenças condenatórias em pecúnia que proferir e aos valores, objeto de acordo homologado, que integrem o salário de contribuição. (ex-OJ no 141 da SBDI-1 - inserida em 27/11/1998)

II - É do empregador a responsabilidade pelo recolhimento das contribuições previdenciárias e fiscais, resultante de crédito do empregado oriundo de condenação judicial, devendo ser calculadas, em relação à incidência dos descontos fiscais, mês a mês, nos termos do art. 12-A da Lei oㅡ 7.713, de 22/12/1988, com a redação dada pela Lei no 12.350/2010.

III - Em se tratando de descontos previdenciários, o critério de apuração encontra-se disciplinado no art. 276, $\S 4^{\circ}$, do Decreto $\mathrm{n} \cong 3.048 / 1999$, que regulamentou a Lei $n^{\circ}$ 8.212/1991 e determina que a contribuição do empregado, no caso de ações trabalhistas, seja calculada mês a mês, aplicando-se as alíquotas previstas no art. 198, observado o limite máximo do salário de contribuição. (ex-OJs ํos 32 e 228 da SBDI-1 - inseridas, respectivamente, em 14/3/1994 e 20/6/2001)."
} 
magistério de Sérgio Pinto Martins ${ }^{90}$, a sentença trabalhista apenas reconhece que a verba era devida e que o fato gerador da contribuição já ocorreu, sem que o sujeito passivo tenha dado cumprimento à sua obrigação legal. O cálculo, portanto, deve ser mês a mês e a alíquota a ser observada é a do mês de competência.

O parágrafo $2^{\circ}$ do artigo 43 da Lei de Custeio estabelece que nas ações trabalhistas de que resultar o pagamento de direitos sujeitos à incidência de contribuição previdenciária, considera-se ocorrido o fato gerador na data da prestação do serviço, quando a remuneração passou a ser devida ${ }^{91}$. Esse reconhecimento, conforme veremos adiante é de suma importância tanto para fins de incidência de juros e multa, quanto para aplicação das regras de prescrição e decadência.

Mesmo no caso de acordo, ressalvado os casos de reconhecimento apenas de verbas de caráter indenizatório, por se tratar de matéria de ordem pública e interesse social, as partes não podem transigir sobre questões legais, decorrentes da modificação do fato gerador ou da base de cálculo do tributo.

Nesse sentido, o inciso III do artigo 97 do Código Tributário Nacional prevê a impossibilidade de modificação do fato gerador por vontade das partes, pois o mesmo decorre sempre de lei.

Para que seja possível a admissão do processo de execução de ofício das contribuições devidas em favor da Seguridade Social em acessoriedade à execução da condenação trabalhista, é condição sine qua non se admitir a constituição prévia do título executivo fiscal, enquanto decorrência lógica da decisão proferida após o encerramento da fase de conhecimento ou do acordo entre as partes do processo devidamente homologado.

É certo que, para a União, a sentença não pode ser considerada título executivo, judicial ou extrajudicial, na medida em que a mesma não é parte no processo na fase de conhecimento.

Diante disso, apenas após a liquidação do decisum trabalhista é que se poderia falar em liquidez e certeza do crédito previdenciário, passando, então,

\footnotetext{
${ }^{90}$ MARTINS, Sérgio Pinto. Execução da Contribuição Previdenciária na Justiça do Trabalho. $3^{\mathrm{a}}$ ed., São Paulo: Atlas, 2008, p. 37.

91 "O fato gerador da contribuição previdenciária é o mês da competência e não o pagamento. Assim, incidem juros e multa de mora em decorrência de pagamento feito fora do prazo legal" (TRT, 2를 R, 8 T., 00133200620302004 (20070618326) Ac. 20070872125, j. 8-10-07, Rel. Juiz Sergio Pinto Martins).
} 
segundo a ótica de Lieban, a ser exigível, enquanto decorrência natural do julgado em favor de terceiro.

A sentença, portanto, não se equipara à condição de fato gerador ou de lançamento tributário. O fato gerador é simplesmente declarado no antecedente normativo da norma individual e concreta inserida no sistema jurídico trabalhista por meio de sentença, posto que se confunde, por sua própria natureza, com o fato pretérito, cuja ocorrência está prevista no ordenamento tributário e que, também, dá ensejo à condenação trabalhista.

Frise-se aqui o entendimento já exposto no presente trabalho de que sobre um mesmo fato social podem incidir ao mesmo tempo várias normas jurídicas, e a sua relevância para o direito só ganha contornos após a fenomenologia da incidência normativa na ação humana. O sujeito competente deve verter em linguagem própria do sistema a que pertence, por relato e declaração do fato pretérito e da subsunção deste à norma geral e abstrata.

O lançamento é o instrumento introdutor próprio e capaz de fazer incidir no sistema jurídico a norma tributária individual e concreta, e nem o magistrado trabalhista ou o Procurador da União, mesmo após intimado para se manifestar sobre os cálculos de liquidação, possuem legitimidade para tanto.

A execução de ofício tem, portanto, natureza sui generis, sendo impossível a sua comparação com aquelas decorrentes de crédito tributário devidamente constituído e inscrito na Dívida Ativa, prevista na Lei $n^{\circ}$ 6.830/80.

Muito se discute em relação à constitucionalidade das Emendas Constitucionais na parte em que se inseriu no texto da Constituição o estabelecimento da competência da Justiça do Trabalho para a execução do crédito de natureza fiscal.

Entretanto, esse não é o objeto do presente estudo, visto que, compartilhando dos dizeres de Sérgio Pinto Martins ${ }^{92}$ :

há presunção de que a emenda constitucional está de acordo com a Constituição, assim como ocorre quando da edição de uma lei que complementa a Lei Maior. Somente em casos excepcionais, em que houvesse a violação direta e literal da Lei Magna, é que se poderia falar em inconstitucionalidade, que não é o da hipótese vertente.

\footnotetext{
${ }^{92}$ MARTINS, Sérgio Pinto. Execução da Contribuição Previdenciária na Justiça do Trabalho. 3ª ed. São Paulo: Atlas, 2008, p. 11.
} 
Ocorre que, tal conclusão não afasta o desconforto dogmático do ponto de vista da incidência normativa, na medida em que o crédito tributário deveria obedecer aos critérios estabelecidos no sistema a que pertence.

O fato é que, se existe a previsão de competência de execução do crédito fiscal, imperativo se admitir que estaria inserido no seio da mesma norma constitucional a certeza de que a incidência da norma previdenciária é automática e concorrente à da norma trabalhista, independentemente de qualquer atividade humana para fins de constituição do crédito.

Dessa feita, no que pertine à contribuição social decorrente de julgados trabalhistas, a norma inserida na legislação de custeio deve incidir automática e infalivelmente, restando controvertida apenas a questão da possibilidade de execução sem título. No mais, a regra guarda muito mais relação com a hipótese de arrecadação na fonte de receita do que propriamente com execução de tributo.

\subsection{Incidência Normativa e Sentença Trabalhista}

Qualquer que seja o instrumento capaz de introduzir a norma jurídica tributária, seja por meio de GFIP ou por meio do e-Social, após a sua implantação definitiva, conforme leciona Paulo de Barros Carvalho ${ }^{93}$, é imprescindível a utilização de uma metodologia científica para colocar o conhecimento à prova de forma ordenada e organizada, evitando assim as contradições de natureza sistemática.

Portanto, para que seja possível um estudo mais aprofundado no tocante à inserção das normas jurídicas no sistema do direito positivo, imperativa a sua análise sob 0 enfoque científico, tentando, principalmente, eliminar as contradições decorrentes das incongruências normativas.

O aspecto pragmático do direito não suprime a possibilidade de conclusões divergentes do ponto de vista científico, reveladas a partir de um corte metodológico que permite a sua total dissecação.

\footnotetext{
93 "O conhecimento sem a utilização da metodologia científica gera notícias desordenadas, dados soltos, que reclamam organização. Assim, só através do conhecimento ordenador da ciência, com o apoio indispensável da Filosofia (e da Lógica), podemos ter um sistema unitário, isento de contradições" (CARVALHO, Paulo de Barros. A Ciência do direito e o direito positivo. Texto inédito.)
} 
O objeto da Ciência do Direito é o universo das normas jurídicas válidas, em um espaço territorial particularmente considerado e momento histórico certo e determinado.

Direito positivo é o tal conjunto de normas jurídicas válidas, em que os enunciados prescritivos só podem ingressar no sistema por força de um efeito jurídico previsto no consequente de uma regra geral e abstrata. Em outras palavras, uma norma jurídica só pode ingressar no sistema do direito positivo por outra norma jurídica, a qual se dá o nome de veículo introdutor ${ }^{94}$.

Comumente reconhecemos esses veículos introdutores pelo nome do ato que os contém, como, por exemplo, a sentença, confundindo-o com o próprio conteúdo do documento normativo.

Nesse contexto, para que uma norma seja inserida no sistema deve ser obedecida uma linguagem jurídica prescritiva de competência, tempo, espaço e procedimento. $O$ desrespeito desses requisitos gera a incompatibilidade da norma com o sistema ao qual deveria pertencer, tornando-a, portanto, inválida aos olhos do cientista.

No presente trabalho, a análise da introdução de norma jurídica estará restrita ao estudo da sentença trabalhista enquanto instrumento capaz de introduzir uma norma jurídica tributária exequível no âmbito da justiça do trabalho, tal qual é permitido pelo texto constitucional.

Não se pretende discutir que na prática isso vem ocorrendo pela prescritividade da norma constitucional, a qual foi inserida no sistema e, até o presente momento, não foi retirada por outra norma jurídica.

A sentença judicial é um instrumento introdutor secundário de norma jurídica, trata-se de um ato normativo estabelecido pela autoridade judicial e produzido no curso de um processo, o qual se dá segundo as regras estabelecidas e integrantes do sistema jurídico.

Sendo a linguagem o suporte maior da atividade jurídica, e o pressuposto de validade da norma a sua observância, é a linguagem competente que dará o subsídio para a pertencialidade de uma norma ao sistema.

\footnotetext{
${ }^{94}$ Nesse contexto citamos os dizeres de Paulo de Barros Carvalho: "Regra jurídica alguma ingressa no sistema do direito positivo sem que seja introduzida por outra norma, que chamamos aqui avante, de veículo introdutor de normas". (Curso de direito tributário, p. 49).
} 
Por linguagem competente, entende-se aquela vertida por sujeito habilitado e que tenha respeitado o procedimento previsto no ordenamento para sua produção. É outra norma jurídica que estabelece a linguagem que deve ser obedecida para cada ato jurídico a ser praticado.

No caso do processo judicial, temos a linguagem das provas como elemento fundamental de subsistência de uma sentença, ou seja, a busca de uma realidade jurídica necessariamente passa pela valoração das provas produzidas pelas partes envolvidas, respeitando sempre os princípios constitucionais da ampla defesa e do contraditório.

A sentença judicial introduz no sistema a norma jurídica individual e concreta, levando em consideração os fatos jurídicos provados nos autos por meio de provas válidas produzidas pelos interessados. Assim, é de fundamental importância que seja garantido às partes o direito de produzir todas as provas que desejarem desde que sejam em direito admitidas e produzidas segundo as regras processuais pertinentes ao sistema a que pertencem.

Nesse ponto, imprescindível a observância do disposto nos artigos 333 do Código de Processo Civil e 818 da CLT, segundo os quais é da parte que alega o ônus de provar o fato constitutivo do seu direito.

A importância dos referidos dispositivos tem consequência direta no momento em que o magistrado, sujeito competente, profere a sua sentença, a qual é o instrumento previsto no ordenamento para introduzir a norma jurídica individual e concreta, que será executada em procedimento próprio, se for o caso.

Não podemos deixar de ter em mente que no processo de conhecimento trabalhista serão produzidas as provas relativas aos direitos laborais dos envolvidos, deixando de lado outras provas que por ventura possam ser fundamentais para a apreciação de relações jurídicas de outras naturezas.

É fato que da relação jurídica trabalhista decorrem outras relações jurídicas, por exemplo, tributária, previdenciária e até criminal. Entretanto, é necessária a utilização de linguagem apropriada para fazer incidir as normas jurídicas previstas em cada um desses ramos do direito.

No caso da contribuição social, especificamente, está previsto no ordenamento jurídico que o fato gerador do tributo é a prestação de serviço, mas para fazer incidir a norma ou, ao menos, constituir o crédito dela decorrente, é necessária a produção de linguagem adequada por meio do preenchimento dos 
formulários de declaração disponibilizados pela receita federal (GFIP) e entrega para homologação.

O fato jurídico tributário decorrente da relação trabalhista tem de ser constituído por uma linguagem própria e competente, em que pese o fato jurídico trabalhista haver se consumado com a assinatura do contrato de trabalho, prestação do serviço e pagamento do salário.

A fenomenologia da incidência tributária é destacada como a atividade humana de aplicação da norma tributária geral e abstrata para a criação de uma norma individual e concreta, por meio da aplicação de uma linguagem competente, o chamado processo de subsunção.

Dessa feita, um mesmo fato social pode sofrer a incidência de mais de uma norma geral e abstrata, vertendo-se, portanto, em mais de um fato jurídico em decorrência desse processo de subsunção realizado pelo homem.

O conceito de incidência tributária vai variar de acordo com a corrente científica referencial utilizada. Para a corrente clássica ou tradicional, da qual fazem parte Pontes de Miranda e Miguel Reale, a incidência é um fenômeno do mundo social, portanto, automática e infalível, na medida em que trabalham com apenas dois planos, o "dever ser" e o "ser".

$\mathrm{Na}$ doutrina ponteana, a incidência da norma é infalível ${ }^{95}$, pois ela deve passar no mundo dos pensamentos e nele ser atendida voluntariamente pelo sujeito passivo. Para ele, o direito não deve ser visto apenas como linguagem, mas como processo de adaptação social, justificando-se a existência da norma jurídica na previsibilidade que toda sociedade necessita.

Reale ${ }^{96}$, por sua vez, com a sua teoria tridimensional do direito, entende que onde quer que haja um fenômeno jurídico, deve existir também um fato subjacente, um valor que confere significação a tal fato e uma norma, que representa a relação ou medida que integra um daqueles elementos ao outro. Esses elementos não podem existir separadamente (fato, valor e norma).

\footnotetext{
95 "A incidência da lei, pois que se passa no mundo dos pensamentos e nele tem de ser atendida, opera-se no lugar, tempo e outros 'pontos' do mundo, em que tenha de ocorrer, segundo as regras jurídicas. É, portanto, infalível". (PONTES DE MIRANDA, Francisco Cavalcante. Tratado de Direito Privado, tomo I. Atualizado por Vilson Rodrigues Alves. Campinas: Bookseller, 1999, p. 53)

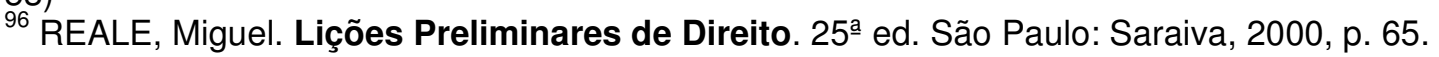


Segundo essa linha de pensamento, a incidência da norma fulminaria o chamado fato social no momento de sua ocorrência, independentemente de qualquer ação humana, que só viria no momento da sua aplicação.

Já na teoria de Paulo de Barros Carvalho ${ }^{97}$, que despreza o fato social no seu estudo científico, a incidência da norma jurídica dependerá da existência de uma linguagem competente que atribua juridicidade ao fato, portanto, não é automática e infalível à ocorrência do evento. Essa corrente divide o fenômeno da incidência em três planos:

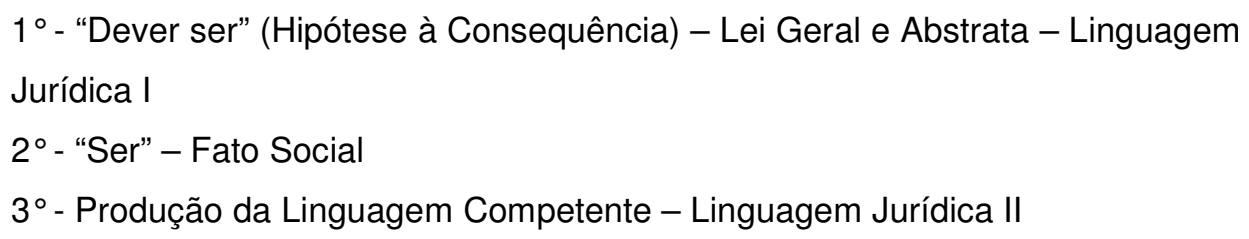

Seguindo a linha dessa corrente, enquanto não houver a atividade humana que atribua linguagem que relacione o fato social com a hipótese normativa, tornando-o jurídico, de modo que, como consequência vincule a relação social entre sujeito ativo e passivo, atribuindo-Ihe juridicidade, inexiste a incidência da norma.

Independentemente da corrente que venha a ser adotada pelo jurista, o fato é que o crédito tributário somente será constituído com a utilização dos mecanismos legalmente estabelecidos para tanto, em que a não utilização destes implica na existência de uma norma jurídica individual e concreta inválida do ponto de vista formal.

As formalidades criadas pelo legislador no âmbito tributário não são meras alegorias normativas, estão lá para preservar o direito do contribuinte em relação ao poder arrecadatório do fisco. Decorrem diretamente do Estado Democrático de Direito e do devido processo legal.

No processo trabalhista, o foco da atividade judicante e o objetivo das provas produzidas estão voltados para a constituição de uma norma jurídica individual e concreta trabalhista, portanto, o eventual crédito decorrente dessa norma, em regra, será da mesma natureza.

${ }^{97}$ CARVALHO, Paulo de Barros. Direito tributário: fundamentos jurídicos da incidência. $9^{\mathrm{a}}$ ed. São Paulo: Saraiva, 2011. 
No caso específico do Direito Tributário, as provas cumprem a finalidade de demonstrar se ocorreu ou não um determinado fato jurídico tributário previsto no antecedente de uma norma individual e concreta, que documenta a incidência tributária, bem como fundamentar os critérios formadores da relação jurídica tributária instaurada pelo consequente.

A emissão de norma individual e concreta de incidência de tributo pode ter como sujeito competente, tanto a administração pública quanto o próprio contribuinte.

O lançamento tributário pode ser definido como 0 ato jurídicoadministrativo pelo qual o sujeito competente, após a subsunção do evento à norma tributária, formaliza a existência de um fato jurídico e de uma obrigação tributária.

Assim, podemos dizer que após a verificação do acontecimento da hipótese normativa de incidência prescrita no antecedente de uma norma geral e abstrata, o sistema do direito tributário fará incidir o consequente normativo dessa mesma norma por meio de outra norma, desta vez individual e concreta.

Nesse sentido, conclui-se que no antecedente de uma norma individual e concreta temos o relato de um fato pretérito, assumindo uma função declaratória. Contudo, no consequente dessa mesma norma, onde se prescreve a relação jurídica propriamente dita, efetivamente é constituída a obrigação ${ }^{98}$.

Como regra, temos a figura do lançamento como o instrumento capaz de introduzir no sistema do direito positivo uma obrigação tributária. É por meio do lançamento que se constitui o crédito dessa natureza.

\footnotetext{
${ }^{98}$ Segundo a lição de Paulo de Barros Carvalho: "Meditemos sobre a construção desse segmento de linguagem. Seu conteúdo semântico será o relato de um evento do passado, devidamente caracterizado no tempo e no espaço. Dizendo de outro modo, o enunciado de que tratamos declara ter ocorrido uma alteração no plano físico-social. Nesse sentido, vale dizer que o fato jurídico tributário tem caráter declaratório. Aí está o motivo pelo qual se aplica ao fato a legislação em vigor no momento em que o evento ocorreu. Entretanto, não podemos esquecer que o relato do acontecimento pretérito é exatamente o modo como se constitui o fato, como essa entidade aparece e é recebida no recinto do direito, o que nos autoriza a proclamá-lo como constitutivo do evento que, sem esse relato, quedaria a margem do universo jurídico. Por outros torneios, o enunciado projeta-se para o passado, recolhe o evento e, ao descrevê-lo, constitui-se como fato jurídico tributário. Retenhamos esses dois aspectos: o enunciado do antecedente da norma individual e concreta que analisamos se constitui como fato ao descrever o evento (...) Pensando assim, a natureza da norma individual e concreta, veiculada pelo ato de lançamento tributário, ou pelo ato produzido pelo sujeito passivo para apurar seu débito, nos casos estabelecidos em lei, assumirá a feição significativa de providência constitutiva de direitos e deveres subjetivos". (CARVALHO, Paulo de Barros. Direito tributário: fundamentos jurídicos da incidência. São Paulo: Saraiva, 2011: Capítulo IV).
} 
O conteúdo do ato de lançamento é a própria norma, que por sua vez, tem também seu conteúdo, consistente em indicar o fato jurídico tributário, cujas notas se subsumem aos critérios da regra-matriz ${ }^{99}$ de incidência, bem como instituem a obrigação tributária, tomada, nesse passo, como equivalente nominal de relação jurídica de caráter patrimonial.

$\mathrm{O}$ ato jurídico administrativo de lançamento tem como atributos a legitimidade e exigibilidade, sendo a sua conceituação como definitivo ou provisório da interpretação do jurista em relação a sua consistência.

Tanto o lançamento quanto o auto de infração são tratados como ato administrativo de competência exclusiva. Entretanto, o primeiro decorre da simples subsunção do fato previsto no antecedente normativo de uma norma geral e abstrata, fazendo emergir a obrigação de pagar tributo, pelo qual o crédito é efetivamente constituído. Já o auto de infração pressupõe a verificação de existência de um ilícito tributário, ou seja, o descumprimento de um fato previsto no antecedente normativo de uma norma geral e abstrata, que tenha no seu consequente a previsão de uma penalidade, cujo direito creditório do sujeito ativo é efetivamente constituído pela prática desse ato.

Assim, enquanto o lançamento decorre de um fato jurídico lícito gerador do pagamento de tributo, tendo como consequente normativo a constituição de um crédito tributário, o auto de infração revela-se quando da ilicitude decorrente do descumprimento de determinada conduta legalmente prevista, seu consequente tem natureza sancionatória.

\footnotetext{
${ }^{99} \mathrm{Na}$ teoria de Paulo de Barros Carvalho, a norma jurídica é uma estrutura lógico-sintática de significação, e é nessa linha que a ciência do direito vem desenvolvendo a concepção de "regra matriz de incidência" (hipótese - consequência). Trata-se de um esquema de incidência tributária, representado por uma fórmula simplificadora. É o mínimo normativo.

A hipótese traz a previsão de um fato de possível ocorrência (dever ser), enquanto a consequência prescreverá a relação jurídica que se vai instaurar, onde e quando acontecer o evento cogitado no suposto normativo.

Hipótese (descritor) a critérios material, temporal e espacial.

Consequência (prescritor) a critérios pessoal (sujeito ativo e passivo) e quantitativo (base de cálculo e alíquota).

Regra Matriz:

$D\{[\mathrm{Cm}$ (verbo+complemento) .Ce . Ct $] \quad[\mathrm{Cp}(\mathrm{Sa}+\mathrm{Sp}) . \mathrm{Cq}$ (base de cálculo $\mathrm{x}$ alíquota) $]\}$

Hipótese normativa

consequente normativo

${ }^{*} \mathrm{Cm}=$ Critério material

${ }^{*} \mathrm{Ce}=$ Critério espacial

${ }^{*} \mathrm{Ct}=$ Critério Temporal

${ }^{*} \mathrm{Cp}=$ Critério Pessoal

* $\mathrm{Sa}=$ Sujeito ativo

${ }^{*} \mathrm{Sp}=$ Sujeito passivo

${ }^{*} \mathrm{Cq}=$ Critério quantitativo
} 
Sob o aspecto prático, quando do auto de infração comumente nos deparamos com dois atos administrativos, um de lançamento (exigência do pagamento do tributo) e outro sancionatório (penalidade pelo descumprimento constatado). De toda sorte, esse aspecto híbrido não retira a natureza jurídica de normas distintas colocadas no mundo jurídico pelo mesmo suporte físico (o auto de infração).

Nosso sistema fez a opção de não considerar lançamento 0 ato do particular que formaliza a obrigação tributária (autolançamento), impondo ao Fisco, ainda que tacitamente, homologar as informações prestadas pelo contribuinte.

Retornando à sentença proferida na justiça laboral, mais especificamente em relação àquela condenatória ou homologatória de acordo, temos a previsão constitucional e legal permitindo que, na execução do crédito trabalhista devidamente constituído pela norma individual e concreta originária daquele sistema jurídico, o magistrado, de ofício, execute também as contribuições sociais previstas no artigo 195, I, a e II, e seus acréscimos legais deles decorrentes.

Para que isso seja possível, do ponto de vista científico, seria imprescindível se admitir que a sentença trabalhista fosse instrumento capaz de substituir o lançamento tributário, na medida em que para execução desse crédito, presume-se a sua prévia constituição.

Uma visão mais superficial poderia contribuir para a conclusão prematura de que, havendo norma geral de estrutura que determine a execução do referido tributo de ofício pelo magistrado trabalhista, estaria inserido no seu conteúdo a norma geral e abstrata de incidência de norma tributária.

A grande incongruência, porém, reside no fato de que talvez a linguagem utilizada na constituição do crédito trabalhista não seja a mais adequada para fazer constituir o crédito tributário, na medida em que os princípios norteadores de cada processo de constituição de crédito são muito distintos, para não dizer antagônicos.

Importante salientar que, em razão do enfoque que é dado durante a fase de conhecimento, nos processos trabalhistas, não se discute pormenorizadamente questões de incidência tributária, sendo elas apresentadas no momento da execução mais como uma consequência lógica do pagamento de 
verbas trabalhistas. Ou seja, o crédito executado jamais foi constituído, trata-se de uma exceção à regra de pré-existência de título executivo.

Os princípios norteadores do processo trabalhista fundamentam uma maneira bastante peculiar de instrução processual, dispensado algumas formalidades inerentes ao processo administrativo e judicial de constituição de crédito tributário, que prima pelo cumprimento das formalidades e documentação dos atos.

Nesse ponto, é imprescindível também a análise da principiologia que rege a administração pública, in casu representada pela autarquia previdenciária (INSS), especialmente em relação ao poder/dever de fiscalização e eficiência no seu desempenho.

A fiscalização que deve ser realizada pelo INSS, no caso de constatação do inadimplemento, deve culminar com o lançamento tributário da contribuição social. Assim, partindo da premissa de que o lançamento é um ato administrativo, ele está subordinado ao seu regime jurídico e, por consequência, aos prazos definidos para a sua efetivação, que devem respeitar o princípio da eficiência.

Tal princípio foi introduzido no rol dos princípios aplicáveis à administração pública. Com o advento da Emenda Constitucional n ${ }^{\circ} 19$ de 4 de junho de 1998, e reza que "toda ação administrava deve ser orientada para concretização material e efetiva da finalidade posta pela lei, segundo os cânones jurídico-administrativos" ${ }^{\text {"100. }}$.

Portanto, ainda que reconhecida a prestação de serviço na justiça do trabalho ou a existência de créditos dela decorrentes, bem como em razão de eventual acordo homologado, nasce com a efetiva prestação do serviço o poder/dever da administração pública de exigir o cumprimento da legislação tributária decorrente daquele evento.

Uma vez definidas tais assertivas, destaca-se a relevância dos institutos da decadência e prescrição no âmbito tributário/previdenciário. A decadência fora definida pelo Código Tributário Nacional, como sendo o prazo dentro do qual o sujeito ativo da obrigação tributária deve constituir o crédito por meio de seu

\footnotetext{
${ }^{100}$ FRANÇA, Vladimir da Rocha. Eficiência administrativa. In: Revista de Direito Administrativo. Rio de Janeiro: Renovar, n. 220, abr./jul. 2000, p. 168.
} 
lançamento ${ }^{101}$, enquanto a prescrição é o período no qual o mesmo sujeito ativo, não satisfeita a obrigação, deve ajuizar a competente ação fiscal.

Conforme já salientamos, uma vez definida a natureza jurídica da contribuição social, aplicam-se a ela, pelo menos desde a Constituição de 1988, todas as normas gerais em matéria de legislação tributária, que estão disciplinadas no Código Tributário Nacional, aprovado pela Lei n5.172/66.

Importante frisar também ser pacificado 0 entendimento de que a execução de contribuição social pela justiça de trabalho limita-se àquelas decorrentes da relação trabalhista, ou seja, apenas em relação à contribuição do empregador incidente sobre rendimentos do trabalho pagos ou creditados, a qualquer título, à pessoa física que lhe preste serviço (artigo 195, I, "a", CF) e à contribuição incidente sobre os rendimentos do trabalhador (artigo 195, II, CF).

Outro ponto que merece destaque é a questão da modalidade de lançamento à que está sujeita contribuição social. O artigo 45 da Lei n‥ 8.212/91 apenas prevê as modalidades lançamento jamais efetuado e lançamento antes efetuado, mas anulado por vício formal, equivalentes ao artigo 173 do CTN, com ressalva dos prazos.

Entretanto, como já vimos, não há como se desconfigurar, salvo nas hipóteses comprovadas de dolo, fraude ou simulação, a modalidade de lançamento por homologação no caso da contribuição social.

Dessa feita, muito dependerá do teor da sentença trabalhista o enquadramento na modalidade de lançamento à que estaria sujeita a contribuição social caso não existisse a demanda judicial, posto que, poderia ser aplicável a regra do artigo 150 ou do artigo 173, ambos do Código Tributário Nacional.

O grande problema é que, quando existe o reconhecimento do crédito tributário no âmbito da Justiça do Trabalho, a sua execução não exige a existência de lançamento e muito menos de inscrição na Dívida Ativa, sendo a sentença o documento capaz e suficiente para executá-lo.

Para Emerson Odilon Sandim ${ }^{102}$, o direito da autarquia previdenciária à execução seria fruto de um ato administrativo denominado "lançamento tributário",

${ }^{101}$ Gian Antonio Michelli, na Itália, chama a atenção para a relação entre a problemática da
natureza (declaratória ou constitutiva) do lançamento e a prescrição (Curso, cit., p. 259) in
AMARO, Luciano. Direito tributário brasileiro. $10^{\text {a }}$ ed. Atual. São Paulo: Saraiva, 2004, p. 389.
${ }_{102}$ Nas palavras do autor "esse lançamento, decorrente do Juiz do Trabalho, é um ato vinculado,
ou seja, emergente da própria outorga constitucional (e, também, na atualidade, decorrente da 
acrescentando, ainda, que esse lançamento, decorrente do Juiz do Trabalho, é um ato vinculado, ou seja, emergente da própria outorga constitucional.

Nessa linha de pensamento, podemos concluir equivocadamente que, na execução previdenciária ex officio na justiça do trabalho, a sentença poderia ser equiparada ao lançamento tributário por expressa autorização constitucional.

Saliente-se que toda a produção de provas e providências contraditórias realizadas pelo propenso contribuinte é realizada de forma indireta no curso da ação trabalhista, uma vez que o processo é todo voltado para a introdução de uma norma individual e concreta trabalhista e tramita regido pelos princípios norteadores desse ramo do direito.

Ademais, já foi visto à exaustão que o lançamento e a inscrição na dívida ativa se tratam de atos administrativos de competência exclusiva da receita federal, sendo impossível a equiparação da sentença trabalhista a qualquer uma dessas hipóteses.

Ponto que merece bastante destaque é a questão do fato gerador da contribuição social e o termo inicial dos prazos de decadência e prescrição no âmbito da Justiça do Trabalho.

Para alguns doutrinadores, como Fábio Zambitte Ibrahim $^{103}$, "a contribuição é devida no momento em que se torna devida a remuneração, é a partir daí (ou do início do exercício subsequente, dependendo do caso) que se terá o termo a quo do prazo decadencial de 5 anos...".

Sob tal ótica, o prazo decadencial começaria a correr a partir do momento que se tornasse devido o crédito decorrente da sentença trabalhista, pouco importando a determinação da legislação tributária que prevê o início do prazo no primeiro dia do exercício seguinte àquele em que o lançamento poderia/deveria ter sido efetuado.

Em desacordo com o referido entendimento, a $1^{\text {a }}$ Turma do TST, no julgamento do Recurso de Revista №. 38500-86.2003.5.24.0051, entendeu que,

CLT, com as alterações da Lei no 10.035/2000). Talvez, até para evitar porvindouras confusões, batizá-lo de lançamento exsententia, neste momento, seja o mais adequado terminologicamente, para, com isso, dissemelhá-lo do afeto à ordem tributária, lançado no plano do processo administrativo". (SANDIM, Emerson Odilon. Novos perfis da execução previdenciária na Justiça do Trabalho. Sinergia entre a Constituição e a Lei 10.035. Exegese sistêmica como meta de otimização. Jus Navigandi, Teresina, ano 5, n. 47, 1ำ nov. 2000. Disponível em: $<$ http://jus.com.br/revista/texto/1442>. Acesso em: 14/10/2011).

${ }_{103}$ IBRAHIM, Fábio Zambitte. Curso de direito previdenciário. 16 ed. Rio de Janeiro: Impetus, 2011, p. 721. 
uma vez assumida a natureza jurídica tributária da contribuição social, sendo o fato gerador a efetiva prestação de serviço, cujo lançamento é feito por homologação, devem ser respeitados os prazos previstos nos artigos 150 e 173 do Código Tributário Nacional, bem como os termos iniciais para contagem dos prazos decadenciais e prescricionais ali previstos ${ }^{104}$.

Por outro lado, o inciso I do artigo 173, do Código Tributário Nacional, que estabelece que a ocorrência do fato gerador (exercício em que o lançamento poderia ter sido efetuado), constitui o marco inicial do prazo extintivo do crédito previdenciário $^{105}$.

Essa miscigenação de conceitos e normas advindas de sistemas tão antagônicos, tributário e trabalhista, acaba por despertar grandes indagações no espírito daqueles que se propõem a interpretar as normas jurídicas inseridas no sistema para viabilizar a execução de ofício da contribuição social no âmbito da justiça do trabalho.

Do ponto de vista da praticidade, sem sombra de dúvida, essa possibilidade assegurou o fortalecimento da arrecadação das contribuições

\footnotetext{
104 Trecho transcrito da decisão: "conforme dispõe o art. 150, § 4º, do Código Tributário Nacional, o lançamento do crédito tributário é feito pela modalidade de homologação - quando o contribuinte adianta o pagamento do tributo sem prévio exame da autoridade competente -, de modo que, não tendo o contribuinte efetuado o adiantamento da parcela, não se há de cogitar acerca da incidência do disposto no aludido preceito legal. Destarte, sendo esse o entendimento adotado pelo acórdão recorrido, não há como reconhecer a violação da literalidade do citado preceito legal".

105 "RECURSO DE REVISTA - CONTRIBUIÇÃO PREVIDENCIÁRIA - PRAZO DECADENCIAL ORIENTAÇ̃O DO EXCELSO SUPREMO TRIBUNAL FEDERAL - EFEITOS EX NUNC SÚMULA VINCULANTE № 8 DO STF. Consagrou o Excelso Supremo Tribunal Federal a inconstitucionalidade dos arts. 45 e 46 da Lei no 8.212/91, e do parágrafo único do art. 5을 do Decreto-Lei no 1.569/77. Assim, não se há de cogitar acerca da violação da literalidade do art. 45 da Lei ํㅡ 8.212/91, dada a sua não observância pelo Tribunal Regional, haja vista a expressa determinação constitucional (art. 146, inciso III, "b") de que somente lei complementar pode regular normas gerais em matéria de legislação tributária, de modo que, em se tratando de preceito oriundo de lei ordinária, não poderia regrar a matéria afeta à decadência. Conforme dispõe o art. 150, $\S 4^{\circ}$, do Código Tributário Nacional, o lançamento do crédito tributário é feito pela modalidade de homologação - quando o contribuinte adianta o pagamento do tributo sem prévio exame da autoridade competente -, de modo que, não tendo o contribuinte efetuado o adiantamento da parcela, não se há de cogitar acerca da incidência do disposto no aludido preceito legal. Destarte, sendo este o entendimento adotado pelo acórdão recorrido, não há como reconhecer a violação da literalidade do citado preceito legal. O art. 173, inciso I, do Código Tributário Nacional - que estabelece que a ocorrência do fato gerador (exercício em que o lançamento poderia ter sido efetuado) constitui o marco inicial do prazo extintivo do crédito previdenciário - foi respeitado, haja vista que foi reconhecida uma relação de emprego de 60 dias no ano de 1992 e de 4 relações de emprego por ano, de 60 dias cada, separadas por interregnos de 15 dias, entre os meses de fevereiro e novembro, nos anos de 1993 a 1998, operando-se a decadência do direito do Instituto às contribuições previdenciárias do período respectivo, pois postulado o direito somente em 2003." (TST - RR 38500-86.2003.5.24.0051. Data de Julgamento: 8/10/2008, Relator Ministro: Luiz Philippe Vieira de Mello Filho, 1ㄹ Turma, Data de Publicação: DEJT 17/10/2008).
} 
sociais quando decorrentes de sentenças trabalhistas. Entretanto, sob um enfoque científico, principalmente quanto à introdução de norma jurídica tributária individual e concreta no sistema do direito positivo por um instrumento introdutor de norma sui generis, pairam algumas questões que permanecem impossíveis de serem validadas pela ciência do direito.

Para se justificar dogmaticamente a constituição do crédito tributário executado de ofício na justiça do trabalho, seria necessário admitir a natureza jurídica de lançamento da sentença trabalhista, o que, conforme vimos, é impossível sob o aspecto científico do direito, na medida em que o lançamento se trata de ato privativo da administração pública, enquanto produto de um procedimento administrativo de apuração.

\subsection{Competência Originária da Justiça Federal}

A primeira questão que vem à mente quando pensamos na execução fiscal de ofício na Justiça do Trabalho é a de que isso pode suscitar eventual conflito de competência com a Justiça Federal.

O inciso I do artigo 109 da Constituição estabelece que a Justiça Federal é o órgão do Poder Judiciário competente para processar e julgar as execuções fiscais relativas às contribuições sociais, na medida em que no polo ativo desse procedimento deve sempre figurar a União, enquanto credora da exação previdenciária.

Com as alterações promovidas pelas Emendas Constitucionais 20/98 e 45/03, estabeleceu-se que as contribuições sociais decorrentes dos acordos homologados e das sentenças proferidas na Justiça do Trabalho devem ser executadas de ofício nos próprios autos do processo trabalhista em sua fase de execução, tudo conforme a atual redação do inciso VIII do artigo 114 da Constituição.

A competência da Justiça Federal, nos termos do dispositivo constitucional é ratione personae, ou seja, definida em razão das pessoas que figuram nos polos da demanda.

Portanto, no caso de determinada execução fiscal ser ajuizada pelo Instituto do Nacional do Seguro Social (INSS), entidade autárquica federal, e excluídas as hipóteses da competência ex officio da Justiça do Trabalho, emerge 
automaticamente a competência da Justiça Federal para processar e julgar a execução fiscal decorrente da incidência da contribuição social.

Por outro lado, a competência da Justiça do Trabalho na execução fiscal das contribuições sociais é ratione materiae, decorrente de alteração na redação da Constituição e fixada restritivamente às hipóteses previstas no inciso VIII do artigo 114.

Dessa feita, fazendo uma interpretação sistemática dos dispositivos constitucionais, podemos estabelecer que tanto a Justiça do Trabalho quanto a Justiça Federal têm competência para apreciar a execução das contribuições sociais, prevalecendo a competência da primeira sempre que verificada as hipóteses materiais decorrentes do artigo 114 e seus incisos. Nesse sentido, inclusive, já se posicionou o Superior Tribunal de Justiça ao ser instado a resolver conflito de competência ${ }^{106}$.

106 "CONFLITO NEGATIVO DE COMPETÊNCIA. JUSTIÇA FEDERAL E TRABALHISTA. EXECUÇÃO FISCAL. CONTRIBUIÇÃO PREVIDENCIÁRIA. INCIDÊNCIA DO ART. 109, I, DA CARTA MAGNA. COMPETÊNCIA DA JUSTIÇA FEDERAL. 1. O Art. 114, incisos VII, VIII e IX, da Carta Magna, por força das alterações engendradas pela promulgação da Emenda Constitucional n.. 45/2004, respectivamente dispõem que: Compete à Justiça do Trabalho processar e julgar: as ações relativas às penalidades administrativas impostas aos empregadores pelos órgãos de fiscalização das relações do trabalho; a execução, de ofício, das contribuições sociais previstas no art. 195, I, a, e II, e seus acréscimos legais, decorrentes das sentenças que proferir; outras controvérsias decorrentes da relação de trabalho, na forma da lei. 2. In casu, trata-se de execução fiscal ajuizada pelo Instituto Nacional do Seguro Social - INSS, objetivando o recebimento de quantia a título de contribuição previdenciária, supostamente devida e não recolhida aos cofres públicos, de natureza eminentemente fiscal advinda de diversas origens, como bem asseverado na decisão suscitante do presente conflito: "A Justiça do Trabalho é manifestamente incompetente para apreciação da matéria. Com efeito, a teor do art. 114, VII e VIII da CF, a competência para os feitos de execução fiscal é restrita a duas hipóteses específicas. A primeira, relativamente às penalidades administrativas aplicadas pelos órgãos de fiscalização do trabalho, matéria estranha à presente demanda. A segunda, concerne à cobrança de contribuições previdenciárias de ofício. Ora, execuções que tais, as quais independem de provocação da União, são restritas às realizadas incidentalmente nos autos de reclamações trabalhistas e não alcançamos feitos de natureza exclusivamente fiscal, como no caso vertente. Registre-se que, em se tratando de matéria de ordem pública, é incabível exegese ampliativa ou extensiva. Ademais, ainda que assim não fosse, pelo que se depreende da certidão da dívida ativa de fls.06/16, a pretensão engloba não só contribuições decorrentes de ações trabalhistas, mas também outras de origens diversas, como as devidas a terceiros (INCRA, SENAI, SESI, SEBRAE), o que, por si só, revela a irregularidade do procedimento adotado". 3. Realmente, é que, conforme decidido pela Primeira Seção no CC no 69268/AL, "1. A competência da Justiça do Trabalho, conferida pelo § $3^{\circ}$ do artigo 114 da Constituição Federal, para executar, de ofício, as contribuições sociais que prevê, decorre de norma de exceção, a ser interpretada restritivamente. Nela está abrangida apenas a execução de contribuições previdenciárias incidentes sobre pagamentos efetuados em decorrência de sentenças proferidas pelo Juízo Trabalhista, única suscetível de ser desencadeada de ofício" 2. Processo de execução movida pelo Instituto Nacional do Seguro Social - INSS para cobrar contribuições sociais descontadas dos empregados e não repassadas à autarquia previdenciária, não está relacionado com cobrança de penalidade imposta por órgão de fiscalização das relações de trabalho." (CC 69268/AL, Rel. Ministro TEORI ALBINO ZAVASCKI, PRIMEIRA SEÇÃO, julgado em 22/11/2006, DJ11/12/2006 p. 304) 4. A causa in foco submete-se à regra geral de competência da Justiça Federal, insculpida no art. 109, I, da Carta Magna de 1988, segundo a qual aos juízes 
Alguns doutrinadores, como Carlos Alberto Pereira de Castro e João Batista Lazzari ${ }^{107}$, entendem que é possível uma situação que imponha uma real inconsistência na questão da fixação da competência, por exemplo, se o mesmo crédito da Seguridade Social, após autuação fiscal, lançamento e inscrição em Dívida Ativa, estiver sendo cobrado judicialmente em sede de Execução Fiscal e, simultaneamente, for objeto de execução ex officio na Justiça do Trabalho, em razão de reclamatória trabalhista promovida por trabalhador.

A situação exemplificada pelos doutrinadores vai ao encontro da teoria da incidência normativa, segundo a qual sobre um mesmo fato social mais de uma norma jurídica pode ser feita incidir, sem que haja o comprometimento das demais.

É certo que o fisco tem o poder-dever de fiscalizar os fatos que possam culminar com a sonegação fiscal e, sendo possível, constituir o seu crédito por meio do procedimento estabelecido no sistema jurídico tributário, introduzindo no universo jurídico a norma individual e concreta, por meio do auto de infração e executá-lo, na Justiça Federal, após a sua inscrição na Dívida Ativa da União.

federais compete processar e julgar: as causas em que a União, entidade autárquica ou empresa pública federal forem interessadas na condição de rés, assistentes ou oponentes, exceto as de falência, as de acidente de trabalho e as sujeitas à Justiça Eleitoral e à Justiça do Trabalho (Precedentes: CC 64565, Rel. Ministro Luiz Fux, DJ 04.08.08; CC 093878, Rel. Min.Castro Meira, DJ 17.3.2008; CC 55540/SP, Rel. Ministra ELIANACALMON, PRIMEIRA SEÇÃO, DJ 26/6/2006; CC 63.643/GO, Rel. Ministro HUMBERTO MARTINS, PRIMEIRA SEÇÃO, DJ 12/02/2007; CC 57.568/GO, Rel. Ministra ELIANA CALMON, PRIMEIRA SEÇÃO, DJ 26/6/2006; CC46.889/SP, Rel. Ministro JOSÉ DELGADO, PRIMEIRA SEÇÃO, DJ28/3/2005; CC 57.095/SP, Rel. Ministra ELIANA CALMON, PRIMEIRASEÇÃO, DJ 26/6/2006) 5. A competência da Justiça Federal é definida em razão das pessoas que figuram nos polos da demanda (ratione personae), à luz do art. 109, I, da Carta Magna. Dessarte, restando a execução fiscal ajuizada pelo Instituto Nacional do Seguro Social - INSS, entidade autárquica federal, e excluídas as hipóteses da competência da Justiça Laboral previstas no art. 114 da CF/88, subjaz a competência da Justiça Federal para processar e julgar o feito principal. 6 . Conflito negativo de competência conhecido para declarar a competência do JUÍZO DA $3^{a}$ VARA FEDERAL DE SANTO ANDRÉ." (STJ, Relator: Ministro LUIZ FUX, Data de Julgamento: 24/2/2010, S1 - PRIMEIRA SEÇÃO)

107 "Pode ocorrer que, em uma ação de Execução Fiscal movida pelo INSS, haja créditos, por exemplo, decorrentes da ação fiscalizatória sobre certa empresa que tinha empregados sem registro - logo, sem efetuar contribuições - e uma ação de um ou mais destes mesmos empregados, contra a empresa, perante a Justiça do Trabalho, em que, procedente o pedido de reconhecimento de vínculo de emprego, passam a ser exigidas as contribuições no curso da execução. A empresa, ao embargar ambas as execuções, alegará a incompetência absoluta de um dos Juízos para a cobrança dos valores em comum. A partir daí, pode-se instalar o conflito positivo de competência; da mesma forma, pode-se ter um conflito de negativo, se o Juiz do Trabalho entender que não deve efetuar a execução de créditos do Instituto Nacional do Seguro Social - INSS de processos em andamento, e o Juiz Federal se der por incompetente, entendendo que é da Justiça do Trabalho a competência." (CASTRO, Carlos Alberto Pereira de; LAZZARI, João Batista. Manual de Direito Previdenciário. 5ª ed. São Paulo: LTr, 2004, p. 367-368). 
Igualmente, a Justiça do Trabalho tem competência para fazer incidir a norma jurídica trabalhista decorrente do mesmo fato, aplicando-a por meio das regras do sistema trabalhista, inserindo a norma individual e concreta exequível por ela própria. Acontece que, com a atribuição de competência de ofício, também, para a execução das contribuições sociais, as quais, via de regra, seriam executadas segundo a sistemática tributária, se torna plenamente possível a hipótese de conflito de competência de difícil resolução pelo Poder Judiciário.

Sérgio Pinto Martins ${ }^{108}$ discorre sobre o tema afirmando que a Justiça Federal tem competência para cobrar as contribuições previdenciárias inscritas na dívida ativa, desde que não sejam decorrentes de sentenças proferidas pela Justiça do Trabalho.

Entretanto, o fato é que as contribuições sociais que por venturam possam decorrer de uma decisão judicial trabalhista também são passíveis de fiscalização da União e, consequente, execução nos termos da Lei $n^{\circ} 6.830 / 80$. Sendo certo que eventual conflito de competência deve ser resolvido pelo instituto da prevenção do juízo que houver primeiro se manifestado.

Nesse contexto, entendemos que a prevenção na Justiça do Trabalho só estará instalada definitivamente com a prolação da sentença, seu trânsito em julgado e, consequentemente, com o início da execução de ofício. Isso porque, se da fase de conhecimento resultar uma sentença meramente declaratória, não se dará início à fase de execução, restando prejudicada a União no seu direito de promover os meios adequados para garantir a arrecadação de seus tributos.

Não há, assim, como se impedir o curso de procedimento administrativo de constituição do crédito tributário com base na pré-existência de reclamatória trabalhista cuja sentença ainda não tenha sido proferida. A União, em função do princípio da eficiência, tem 0 dever constitucional de se movimentar proativamente no sentido de alcançar o seu crédito, e da sua inércia pode resultar, inclusive, a extinção deste em razão do decurso dos prazos decadencial e prescricional.

O fisco não pode simplesmente ser compelido a aguardar o desfecho da lide trabalhista para então agir em busca do auferimento do seu crédito, estaria a se comportar desidiosamente, na medida em que o processo trabalhista pode,

\footnotetext{
${ }^{108}$ MARTINS, Sérgio Pinto. Execução da Contribuição Previdenciária na Justiça do Trabalho. 3 a ed., São Paulo: Atlas, 2008, p. 31.
} 
inclusive, culminar com a sua extinção sem reconhecimento de mérito após anos de tramitação, período esse, talvez, determinante para o reconhecimento, ou não, da decadência ou prescrição fiscal. Até porque, se a execução trabalhista restar infrutífera, não poderá a União inscrever o crédito em Dívida Ativa e cobrá-lo na Justiça Federal, conforme elucidado por Sergio Pinto Martins na obra suprarreferida.

O espírito da norma constitucional inserida no inciso VIII do artigo 114 da Constituição foi o de preservar a arrecadação, posto que as decisões trabalhistas podem ter implicações na concessão de benefícios, sendo imprescindível para a manutenção do sistema da Seguridade Social a pré-existência de custeio para o percebimento das parcelas previdenciárias.

Nesse contexto, se ao tempo do início da execução trabalhista o crédito tributário dela decorrente já houver sido inscrito na Dívida Ativa da União, enquanto resultado de procedimento administrativo fiscal obrigatório, a Justiça do Trabalho haverá de ser reconhecida como incompetente para executar de ofício as contribuições sociais decorrentes de seu julgado, uma vez que já integrantes de título executivo extrajudicial e garantido o seu percebimento por parte do fisco federal.

\subsection{Due Process of Law e a Ausência de Impugnação Específica}

Inserido expressamente em nosso ordenamento jurídico por meio da atual Constituição, o devido processo legal é dos princípios constitucionais um dos mais importantes, pois somente por meio dele é que se consegue atingir os demais princípios e garantias. Trata-se de direito fundamental do homem consagrado na Declaração Universal dos Direitos Humanos ${ }^{109}$.

O Direito Processual mais moderno tem admitido concepção de que o devido processo legal deve ser garantido substancialmente, inclusive, mediante o estabelecimento de limitações ao poder estatal. De acordo com o magistério de Paulo Henrique dos Santos Lucon ${ }^{110}$, essa limitação visa censurar a própria

\footnotetext{
109 "Art. $8^{\circ}$ Todo o homem tem direito a receber dos tribunais nacionais competentes remédio efetivo para os atos que violem os direitos fundamentais que the sejam reconhecidos pela constituição ou pela lei."

${ }^{110}$ LUCON, Paulo Henrique dos Santos. Devido Processo Legal Substancial. Artigo escrito para a Academia Brasileira de Direito Processual Civil - ABDPC, visualizado em 14/12/2014. (www.abdpc.org.br/artigos/artigo1015.doc)
} 
legislação, ao ponto de se admitir a declaração de ilegitimidade de leis que violem as grandes colunas ou os landmarks do regime democrático.

Cândido Rangel Dinamarco ${ }^{111}$, por sua vez, entende que essa autolimitação estatal está inserida em um contexto de que, no exercício de sua jurisdição, o Estado deve estar pautado no respeito nas demais garantias e exigências. Essa limitação, portanto, autorizaria ao julgador discutir a razoabilidade de determinada norma e a justiça das decisões estatais, estabelecendo o controle material da constitucionalidade e da proporcionalidade.

As noções de proporcionalidade e razoabilidade, muitas vezes, se confundem, por estabelecerem uma interdependência. A proporcionalidade sempre leva em consideração a comparação entre duas possibilidades juridicamente possíveis, enquanto a razoabilidade representa um padrão de avaliação geral.

Do devido processo legal derivam outros postulados imprescindíveis ao processo, por exemplo, os princípios do contraditório, da ampla defesa e da motivação das decisões, havendo nítida integração entre os incisos LIV e LV do artigo $5^{\circ}$ da Constituição.

Nesse diapasão, o estabelecimento de critérios distintos de execução do mesmo crédito tributário, dependendo do mecanismo de apuração deste (administrativamente ou decorrente de sentença trabalhista), poderia de alguma forma afetar o curso desse devido processo legal, visto que naquele que decorre como consequência lógica da decisão proferida na Justiça Laboral, inexiste um procedimento prévio e específico de apuração e discussão dos componentes do tributo (fato gerador, base de cálculo, alíquota, prescrição e decadência).

Ademais, quando tratamos a execução de ofício na Justiça do trabalho, estamos falando de um crédito que jamais foi constituído formalmente, já que o lançamento e a autuação fiscal seriam os únicos mecanismos juridicamente previstos para o fim de se apurar, declarar e constituir a obrigação tributária, o que não ocorre nos termos do inciso VIII do artigo 114 da Constituição.

\footnotetext{
111 "proclamar a autolimitação do Estado no exercício da própria jurisdição, no sentido de que a promessa de exercê-la será cumprida com as limitações contidas nas demais garantias e exigências, sempre segundo os padrões democráticos da República brasileira" (DINAMARCO, Cândido Rangel. Instituições de Direito Processual Civil. V. I. $4^{\mathrm{a}}$ ed. São Paulo: Malheiros, 2004, p. 245.)
} 
Guilherme Guimarães Feliciano ${ }^{112}$ defende que cabe ao exegeta privilegiar a inteligência dos textos de forma a tornar viável a sua aplicação, de modo que com a abertura de oportunidade para que o INSS se manifeste na fase de execução, inclusive, para discutir a base de cálculo do tributo, estaria suprida a necessidade de observância de um contraditório mais específico.

Entretanto, com a devida vênia para discordar, entendo que essa abertura de procedimento para discussão do crédito por parte do fisco não afasta a inconsistência da norma do ponto de vista dogmático, na medida em que no âmbito do Direito Tributário a parte hipossuficiente é o contribuinte e a ele é que deve ser garantido o contraditório e ampla defesa plenos.

Destaca-se aqui que, na fase de conhecimento do processo do trabalho, o objeto da prova e da argumentação jurídica é a relação laboral que se levou ao crivo do judiciário para apreciação, e a tributação decorrente do reconhecimento de determinado fato por aquela justiça emerge enquanto consequência prática, não se discute especificamente a incidência da norma tributária.

Ademais, na apuração do crédito tributário, nos termos da legislação fiscal, devem ser respeitadas formalidades documentais muitas vezes dispensadas no reconhecimento do fato trabalhista, pois a oralidade é um dos princípios norteadores do processo do trabalho.

Muito embora possamos exercitar um raciocínio lógico para dar praticidade e eficácia à norma arrecadatória inserida por meio das Emendas Constitucionais 20/98 e 45/03, por meio do qual justificaríamos o diferimento do contraditório na execução em ambiente trabalhista, o qual se dá por embargos do devedor da contribuição social, o devido processo legal, enquanto objetivo a ser atingido pelo Estado, não parece atingir patamares de razoabilidade, pois a existência de mecanismos distintos e a exigência de formalidades antagônicas, em razão da autoridade que executará o tributo, afronta o padrão juridicamente esperado para fins de incidência tributária, o qual deveria estar previsto em um único sistema jurídico.

Seguindo essa lógica, a sentença trabalhista ao declarar um fato jurídico passível, também, de tributação, no máximo poderia servir de meio de prova para fins de incidência tributária, na medida em que para fazer incidir aquela norma,

112 FELICIANO, Guilherme Guimarães. Execução das contribuições sociais na justiça do trabalho. São Paulo: LTr, 2002, p. 61-63. 
seria necessária a utilização de instrumentos introdutores específicos para o sistema jurídico tributário, os quais, após o contraditório e a ampla defesa específicos, podem constituir o crédito por meio do lançamento ou auto de infração, sendo a execução possível após a sua devida inscrição na Dívida Ativa da União. 


\section{OS EFEITOS PREVIDENCIÁRIOS}

O objetivo maior do inciso VIII do artigo 114 da Constituição é a garantia da arrecadação da fonte de custeio da Seguridade Social, na medida em que a declaração de fatos jurídicos trabalhistas deveria, em tese, implicar em consequências previdenciárias, como a concessão de benefício em função do acúmulo de tempo de contribuição por parte do trabalhador.

Analisada a forma como se dá essa execução tributária em sede trabalhista, em razão da competência constitucional atribuída ao magistrado com tal jurisdição, e diante da ausência de qualquer extensão de sua competência para fins de determinação da inserção de dados nos cadastros mantidos pelo INSS, importante avaliarmos quais os efeitos previdenciários dos julgados produzidos na Justiça do Trabalho.

Em que pese as inconsistências dogmáticas no tocante à inserção da norma jurídica tributária por meio da sentença trabalhista, o fato é que na prática isso vem ocorrendo independentemente da pré-existência de um justo título exequível na Justiça do Trabalho, ou seja, independentemente do caráter ilógico de execução de um crédito jamais constituído, a sentença trabalhista vem produzindo efeitos tributários em obediência ao comando constitucional.

Assim, será abordada no presente capítulo a importância da Seguridade Social enquanto razão de existência da contribuição bem como e, principalmente, o procedimento de concessão de benefício pelo INSS em consequência da inserção de dados no Cadastro Nacional de Informações Sociais (CNIS) e as implicações práticas do reconhecimento de fatos trabalhistas em decisões judiciais.

Por fim, diante da importância do custeio para o desencadeamento dos efeitos previdenciários decorrentes do trabalho, diante do caráter contributivo imposto pela Emenda Constitucional $n^{\circ} 20 / 98$, será traçado o paralelo entre a reciprocidade contributiva e a execução de ofício a ser promovida pela Justiça do Trabalho. 


\subsection{Seguridade Social}

A Seguridade Social pode ser definida como sendo um sistema jurídico, composto por princípios, regras e instituições cuja destinação é garantir a ampla proteção social dos indivíduos que se encontrem em situação de não o poderem fazer por seus próprios esforços.

Essa preocupação com os infortúnios decorrentes da fome, doença, velhice, entre outros, tem sido uma constante da humanidade. De toda sorte, o Estado só veio tomar alguma providência concreta no século XVII, com a edição da Lei dos Pobres, criada no final do reinado da Rainha Elizabeth, como resposta às necessidades da população e às pressões sofridas pelo Estado para supri-las.

Fábio Zambitte Ibrahim ${ }^{113}$, ao discorrer sobre a origem da proteção social, afirma que os conceitos sociais-democratas acabaram por ser os responsáveis pela construção do Welfare State, ou Estado do Bem-Estar Social, que tem exatamente o objetivo de atender a outras demandas da sociedade, como a Previdência Social.

É certo que essa ideia de Bem-Estar Social surgiu no continente europeu muito mais em razão do combate ao comunismo, do que propriamente por conta de uma preocupação com a proteção social. Entretanto, nos tempos atuais esse modelo traz um dimensionamento do Estado na exata proporção de sua necessidade e adequação ao bem comum, sem exageros.

O Brasil segue, de certa forma, essa lógica, e a Constituição traz em seu bojo a previsão de um Estado do Bem-Estar Social em nosso território, sendo de responsabilidade estatal essa proteção. Para atender a essa obrigação constitucional, o Estado impõe contribuições obrigatórias a todos os trabalhadores.

A Seguridade Social é classificada como direito social na Constituição, usualmente enquadrada entre os direitos fundamentais de segunda geração.

O objetivo do constituinte originário, ao inseri-la em nosso ordenamento jurídico, foi a criação de um sistema protetivo, o qual não existia antes em nosso país. É, portanto, obrigatória essa intervenção estatal visando ao bem estar humano.

\footnotetext{
${ }^{113}$ IBRAHIM, Fábio Zambitte. Curso de Direito Previdenciário. 16 ${ }^{\underline{a}}$ ed. rev., ampl. e atual. Rio de Janeiro: Impetus, 2011, p. 3-4.
} 
Wagner Balera ${ }^{114}$ atribui grande importância ao alcance dos valores do bem-estar social e da justiça social, as bases do Estado brasileiro. A seguridade é, nesse contexto, o mecanismo social capaz de possibilitar o atingimento do fim maior, a justiça.

O artigo $3^{\circ}$ da Constituição prevê a erradicação da pobreza e da marginalização, bem como a redução das desigualdades sociais e regionais como objetivos fundamentais da República Federativa do Brasil, sempre sob o fundamento da dignidade humana.

Logicamente que o atingimento desses objetivos não deve se dar por meio da concessão de benefícios de forma desenfreada, o que poderia colimar com um total desequilíbrio financeiro e atuarial do sistema. A melhor forma de se atingir os objetivos dessa ordem social é a promoção do desenvolvimento e distribuição de renda pelo trabalho.

Até mesmo porque, a sustentabilidade da Seguridade Social depende da contribuição vertida por aqueles cidadãos economicamente ativos, os quais, por meio do trabalho, contribuem e geram outras fontes de custeio, por exemplo, a do empregador incidente sobre a folha de pagamento, entre outras.

Jean-Jacques Rousseau ${ }^{115}$ foi um dos expoentes do desenvolvimento desse modelo de intervenção estatal com o intuito de minimizar as desigualdades sociais. O referido pensador é muito citado enquanto defensor do fim da propriedade e das desigualdades por meio da gestão estatal do mercado, entretanto, fez questão de que fizesse parte de sua obra a sua preocupação com

\footnotetext{
${ }^{114}$ BALERA, Wagner. Noções Preliminares de Direito Previdenciário. São Paulo: QuartierLatin, 2004 , p. 15 a 39.

115 "Tratei de expor a origem e o progresso da desigualdade, o estabelecimento e o abuso das sociedades políticas, tanto quanto essas coisas se podem deduzir da natureza do homem pelas luzes exclusivas da razão e, independentemente dos dogmas sagrados que dão à autoridade soberana a sanção do direito divino. Resulta do exposto que a desigualdade, sendo quase nula no estado de natureza, tira a sua força e o seu crescimento do desenvolvimento das nossas faculdades e dos progressos do espírito humano, tornando-se enfim estável e legítima pelo estabelecimento da propriedade e das leis. Resulta ainda que a desigualdade moral, autorizada unicamente pelo direito positivo, é contrária ao direito natural todas as vezes que não concorre na mesma proporção com a desigualdade física. Essa distinção determina suficientemente o que se deve pensar, nesse sentido, da espécie de desigualdade que reina entre todos os povos policiados, pois é manifestamente contra a lei de natureza, de qualquer maneira que a definamos, que uma criança mande num velho, que um imbecil conduza um homem sábio, ou que um punhado de pessoas nade no supérfluo, enquanto à multidão esfomeada falta o necessário." (ROUSSEAU, Jean-Jaques. Discurso sobre a Origem da Desigualdade entre os Homens. Disponível em http://www.dominiopublico.gov.br/download/texto/cv000053.pdf, consulta em 21/11/2014, às 22h.)
} 
os efeitos perversos da economia, principalmente em relação aos mais necessitados.

O que devemos extrair de tudo o que vimos até aqui é que a Seguridade Social, na forma como estabelecida no Brasil, em que pese depender de certa intervenção estatal, que organiza o custeio e concede os benefícios e os serviços, ainda sim, é um conjunto de ações da qual faz parte a sociedade como um todo, sendo a proteção do cidadão o centro das atenções desse sistema.

Esse cidadão será atendido sempre que verificada a ocorrência de uma das hipóteses das contingências ${ }^{116}$ legalmente previstas, as quais demandam a intervenção estatal em prol da manutenção da dignidade humana.

A sociedade participa desse sistema, principalmente, por meio do custeio, sendo certo que o indivíduo trabalhador contribui especificamente para garantia de cobertura de uma parcela dessas contingências, quais sejam, aquelas decorrentes do pagamento de benefícios previdenciários.

Antes de tratarmos um pouco do custeio da seguridade social, que é o mecanismo por meio do qual o Estado consegue atender ao comando constitucional de cobertura dos eventos sociais que ensejam a sua intervenção, passemos brevemente pelos princípios norteadores desse sistema, em especial aqueles que de alguma forma influem na interpretação dos efeitos que se deve atribuir à sentença trabalhista enquanto instrumento capaz de introduzir uma norma previdenciária individual e concreta.

Os princípios específicos da seguridade social estão inseridos no artigo 194 da Constituição. Miguel Reale ${ }^{117}$ define os princípios como sendo as "verdades fundantes" de um sistema.

Um dos postulados da Seguridade Social está inserido no princípio do solidarismo, o qual, em que pese não constar expressamente no texto constitucional, traz a ideia de que toda sociedade, indistintamente, tem o dever de contribuir para a sua manutenção, ainda que não venha a se beneficiar dos benefícios e serviços disponibilizados. Por exemplo, o empregado que contribui para manutenção da seguridade, provavelmente não se beneficiará dos serviços

\footnotetext{
116 "A Convenção 102 da OIT considera como contingências: idade avançada, invalidez, morte, enfermidade, maternidade, acidente do trabalho, prestações familiares, desemprego e tratamento médico." (MARTINS, Sérgio Pinto. Direito da Seguridade Social. 33를 ed. São Paulo: Atlas, 2013, p. 22).

${ }^{117}$ REALE, Miguel. Lições Preliminares de Direito. São Paulo: Saraiva, 2003, p. 303.
} 
inerentes à assistência social, pois já está coberto pela previdência, mas as contribuições decorrentes de sua prestação de serviço também farão parte do custeio de forma geral ${ }^{118}$.

Entre os princípios expressamente previstos na Constituição, temos o da universalidade da cobertura e do atendimento ${ }^{119}$ (artigo 194, I, Constituição Federal), o qual consiste na promoção indiscriminada do acesso aos serviços e benefícios previstos no ordenamento, visando à proteção da sociedade dos riscos sociais previstos nesse sistema jurídico.

Ainda, sob a ótica do presente estudo, temos o princípio da equidade na forma de participação no custeio, o qual tem ampla relação com o a capacidade contributiva, previsto enquanto princípio do sistema tributário brasileiro, segundo o qual os indivíduos contribuem para a seguridade social na proporção de suas possibilidades.

Dentre outros princípios, o da diversidade da base de financiamento também se destaca para os fins interpretativos desejados neste trabalho, pois a Constituição prevê que o custeio da seguridade social deve estar lastreado em uma base ampla, a qual tem a participação dos trabalhadores, das empresas e dos orçamentos dos entes estatais, entre outros.

Por fim, o princípio da preexistência do custeio em relação aos benefícios ou serviços (artigo 195, $\S 5^{\circ}$, Constituição Federal), o qual tem por finalidade maior a manutenção do equilíbrio da seguridade social ${ }^{120}$.

118 "A solidariedade pode ser considerada um postulado fundamental do Direito da Seguridade
Social, previsto implicitamente inclusive na Constituição. Sua origem é encontrada na assistência
social, em que as pessoas faziam uma assistência mútua para alguma finalidade e também com
base no mutualismo, de se fazer um empréstimo ao necessitado. É uma característica humana,
que se verifica no decorrer dos séculos, em que havia uma ajuda genérica ao próximo, ao
necessitado. (...) Ocorre solidariedade na Seguridade Social quando várias pessoas economizam
em conjunto para assegurar benefícios, quando as pessoas do grupo necessitarem. As
contingências são distribuídas igualmente a todas as pessoas do grupo. Quando uma pessoa é
atingida pela contingência, todas as outras continuam contribuindo para a cobertura do benefício
do necessitado." (MARTINS, Sérgio Pinto. Direito da Seguridade Social. $33^{a}$ ed. São Paulo:
Atlas, 2013, p. $53-54)$.
119 "Dessarte, com o fim de eliminar a miséria, o princípio da universalidade, na seguridade social,
agasalha todas as pessoas que dela necessitam (universalidade subjetiva) ou que possam vir a
necessitá-la nas situações socialmente danosas (universalidade objetiva), ou seja, eventualidades
que afetem a integridade física ou mental dos indivíduos, bem como aquelas que atinjam a
capacidade de satisfação de suas necessidades individuais e de sua família pelo trabalho."
(CORREIA, Marcus Orione Gonçalves. Curso de Direito da Seguridade Social. $2^{a}$ ed. São
Paulo: Saraiva, 2002, p. 73 ).
120 "Princípio comezinho da boa administração pública, em consonância com o qual somente
podem ser feitos gastos quando previamente estabelecidas as fontes de custeio." (DIAS, Eduardo 
Diante dos princípios supramencionados, fica evidente que os pilares da seguridade social encontram-se no fortalecimento do custeio e na garantia de cobertura mais abrangente possível, em que o segundo depende crucialmente do primeiro.

É certo que a alteração constitucional que ampliou a competência da Justiça do Trabalho, incluindo o dever de executar de ofício as contribuições sociais decorrentes de seus julgados, de alguma forma contribui para o atingimento de uma parcela dessa estrutura, mas exclui, por outro lado, o comando constitucional que visa à ampla cobertura, inclusive da previdenciária, na medida em que o dispositivo constitucional não atribuiu ao magistrado a mesma autonomia para conferir efeitos previdenciários aos seus julgados.

Quanto à sua natureza jurídica, podemos dizer que a Seguridade Social é um dos ramos do Direito Público, decorrente da lei, que envolve contribuinte, beneficiários e o Estado, e este último é o encarregado pela arrecadação, administração e retribuição em favor dos cidadãos, nos limites do ordenamento jurídico.

Nos termos do inciso XXIII do artigo 22 da Constituição, é de competência da União legislar sobre a Seguridade Social. Outrossim, o direito tributário é fonte normativa subsidiária em função da sua estreita relação com o custeio.

Esse sistema encontra previsão constitucional nos artigos 194 a 204 e compreende o conjunto integrado de ações dos Poderes Públicos e da sociedade, visando assegurar os direitos relativos à saúde (artigo 196), à previdência (artigo 201) e à assistência social (artigo 203).

Fazendo uma análise comparativa mais grosseira da finalidade de cada segmento que compõe a Seguridade Social, podemos dizer que a previdência é responsável pelo pagamento de benefícios, a saúde assegura serviços e a assistência fornece ambos. A diferença principal está na necessidade de contraprestação para fruir desses serviços e benefícios, em que apenas a Previdência Social exige a preexistência de contribuição do cidadão individualmente.

A saúde, conforme estabelecido pela própria Constituição, é direito de todos e dever do Estado, sendo irrelevante qualquer contraprestação para que 
nasça o direito subjetivo do cidadão desfrutar do aparato público destinado ao cumprimento da ordem constitucional. A assistência social, por sua vez, nos termos do caput do artigo 203, tem na gratuidade a sua característica fundamental, assim, independentemente de contribuição, visa à proteção à família, à maternidade, à infância, à adolescência e à velhice, assim como aos deficientes e também para os que necessitam de reintegração ao mercado de trabalho.

Dessa feita, podemos dizer, com boa margem de segurança, que aqueles que contribuem para o custeio do sistema da Seguridade Social devem ter como direito subjetivo, além do acesso à saúde e à assistência, a proteção previdenciária, a qual se efetiva por meio do pagamento de benefícios correspondentes à contingência-necessidade do segurado.

A Previdência Social, portanto, tem um caráter eminentemente contributivo, na medida em que, ao contrário dos outros dois seguimentos da Seguridade Social, o custeio do sistema baseado nas contribuições sociais dos trabalhadores é condição sine qua non para o gozo das coberturas dos riscos sociais previstos no ordenamento jurídico.

\subsection{Arrecadação Enquanto Mecanismo de Manutenção do Sistema}

Em que pese a nossa Constituição adotar uma política de proteção universal, independentemente de contribuição ${ }^{121}$, o custeio decorrente da diversidade na sua base de financiamento ainda é o que garante a subsistência de um regime bem-sucedido na promoção do bem-estar e da justiça social.

É certo que a Emenda Constitucional $n^{\circ} 29$, de 2000, trouxe a previsão da participação dos entes federativos na manutenção da Seguridade Social, o que se dá por meio de aplicações anuais de recursos mínimos derivados de percentuais calculados sobre a arrecadação de tributos.

Determina o artigo 195 e seus incisos, da Constituição, que a seguridade social será financiada por toda a sociedade, de forma direta e indireta, mediante recursos provenientes dos orçamentos da União, dos Estados, do Distrito Federal e dos Municípios, bem como daqueles provenientes das contribuições sociais.

\footnotetext{
${ }^{121}$ IBRAHIM, Fábio Zambitte. Curso de Direito Previdenciário. 16 $6^{\underline{a}}$ ed. rev., ampl. e atual. Rio de Janeiro: Impetus, 2011, p. 9.
} 
A sociedade financia diretamente a seguridade por meio das contribuições socais, as quais, em razão da atribuição de competência de arrecadação da Justiça do Trabalho, serão o núcleo de nossa pesquisa. Mesmo não sendo a única fonte de receita do sistema protetivo, sem dúvida nenhuma, é a mais importante, principalmente quando pensamos nos benefícios concedidos pela previdência social.

A competência para instituir as contribuições sociais, nos termos do artigo 149 da Constituição é da União. Assim, em razão de sua natureza tributária, estas estão sujeitas às limitações constitucionais do poder de tributar e às normas gerais de direito tributário, conforme expressamente previsto no inciso III do artigo 146.

O sujeito ativo das contribuições sociais, em decorrência das alterações trazidas pela Medida Provisória ${ }^{\circ}$ 222/04, convertida na Lei n 11.098/05, passou a ser o Ministério da Previdência Social - MPS, órgão que tem a incumbência de arrecadar, lançar e normatizar o recolhimento desse tributo. A referida lei autorizou a criação da Secretaria da Receita Previdenciária, a qual foi implementada pelo Decreto $n^{\circ} 5.256 / 04$ e tem por objetivo maior eficiência na arrecadação.

Posteriormente, com a Lei $n^{\circ} 11.457 / 07$, que revogou diversos dispositivos da referida Lei de 2005, criou a Secretaria da Receita Federal do Brasil, unificando a Receita Federal e a Receita Previdenciária, passando a ser da União a competência plena de todas as contribuições sociais, ficando a cargo do INSS a competência restrita para gerir os benefícios e serviços da seguridade social.

Dentre as pessoas e bases econômicas previstas no artigo $195 \mathrm{da}$ Constituição, estão previstos nos incisos I e I| o empregador e o trabalhador enquanto fonte direta de custeio da seguridade, o que reforça a tese de que a promoção do bem-estar e da justiça social está diretamente relacionada com a garantia de emprego, na medida em que o próprio regime de serviços e benefícios tem como fonte de receita a tributação decorrente dessa relação de trabalho.

A conceituação de empresa e seus equiparados encontram-se definida no artigo 15 da Lei de Custeio, sendo tributados tanto sobre a folha de salários e demais rendimentos do trabalho pagos ou creditados, a qualquer título, à pessoa 
física que Ihe preste serviço, mesmo sem vínculo empregatício, quanto sobre seu faturamento e lucro líquido.

É certo que deve haver um equilíbrio por parte do legislador, uma vez que a oneração em demasia da folha pode acabar desestimulando a contratação de mão de obra e, por consequência, ter efeito negativo na arrecadação, desequilibrando o sistema.

Pensando nisso, está pendente de lei que assim defina a substituição total ou parcial da contribuição incidente sobre a folha pela COFINS, conforme previsão do parágrafo 13 do artigo 195 da Constituição.

Fabio Zambitte Ibrahim $^{122}$ entende que a previsão do referido dispositivo afronta o princípio constitucional que prevê a diversidade da base de financiamento da seguridade social, principalmente, se levado em consideração que os recursos provenientes da COFINS, ao arrepio da previsão inserida no inciso XI do artigo 167 da Constituição, raramente são direcionados para o custeio desse sistema, e essa substituição pode reduzir sensivelmente a sua receita, em especial, a da previdência.

Outra fonte de receita da seguridade social, que tem relação direta com o desenvolvimento econômico e, em razão disso, com a garantia de trabalho, é aquela prevista no inciso I do artigo 195 da Constituição, o lucro. É devida pelo empregador pessoa jurídica, tendo como base de cálculo o lucro líquido contábil, ressalvadas as exceções trazidas pela Lei $n^{\circ} 10.684 / 03$.

Além das contribuições do empregador, o trabalhador também é sujeito passivo de obrigação tributária destinada ao custeio da seguridade social, seja na qualidade de empregado ou prestador de serviço, em que a base de cálculo de incidência é o salário de contribuição.

Cumpre-se destacar que, da mesma forma que a contribuição incidente sobre a folha de pagamento, a incidente sobre a remuneração do trabalhador também é destinada exclusivamente ao custeio dos benefícios concedidos pelo Regime Geral de Previdência Social ${ }^{123}$.

\footnotetext{
${ }^{122}$ IBRAHIM, Fábio Zambitte. Curso de Direito Previdenciário. 16 ${ }^{\underline{a}}$ ed. rev., ampl. e atual. Rio de Janeiro: Impetus, 2011, p. 91.

123 "Art. 167. São vedados:

(...) XI - a utilização dos recursos provenientes das contribuições sociais de que trata o art. 195, I, a, e II, para a realização de despesas distintas do pagamento de benefícios do regime geral de previdência social de que trata o art. 201."
} 
Há ainda outras tantas fontes de incidência tributária cuja destinação é, também, o financiamento da seguridade, entretanto, o inciso VIII do artigo 114 da Constituição prevê apenas a competência da Justiça do Trabalho para a execução, de ofício, das contribuições sociais previstas no artigo 195, I, a, e II.

O que se pretende demonstrar é a importância do custeio da seguridade social como um todo, em que a origem das receitas que se destinam a esse fim estão diretamente relacionadas com o desenvolvimento econômico e a garantia de trabalho.

Nesse diapasão, ainda que seja inerente ao regime certa intervenção do Estado na sua manutenção, a sociedade é grande responsável pela sua viabilização, na medida em que, sem a contribuição social do particular, ainda que impositiva, se tornaria impossível a sustentabilidade desse sistema protetivo.

Por fim, discussões dogmáticas à parte, a inserção da competência para a execução de ofício da contribuição social decorrentes de seus julgados pela justiça do Trabalho se mostra, sim, uma ferramenta interessante e, de certa forma, eficiente de arrecadação e combate à sonegação. Principalmente, porque as contribuições que se executam nessa justiça são aquelas diretamente vinculadas à remuneração do trabalhador.

\subsection{Previdência Social e a Concessão de Benefícios}

Para o presente estudo, é importante focarmos as nossas atenções ao seguimento da seguridade social, que tem maior correlação com o direito do trabalho, a Previdência Social.

Por óbvio que as sentenças trabalhistas podem declarar direitos por meio do reconhecimento de fatos jurídicos, os quais, em relação à seguridade social, terão mais afinidade com a questão da concessão de benefícios previdenciários, na medida em que é exatamente em função da prestação de serviço remunerado que emerge a obrigação de contribuir e, por consequência, o direito de usufruir do plano de cobertura dos infortúnios sociais previstos na Lei de Benefícios.

Wladimir Novaes Martinez ${ }^{124}$ conceitua previdência social como uma técnica de proteção social, a qual tem por objetivo proporcionar aos segurados os

\footnotetext{
${ }^{124}$ MARTINEZ, Wladimir Novaes. A Seguridade Social na Constituição Federal. $2^{a}$ ed. São Paulo: LTR, 1992, p. 83.
} 
meios indispensáveis à sua subsistência, sob a ótica da dignidade humana, quando estes não puderem obtê-los ou não for socialmente desejável que os aufira pessoalmente por meio pelo trabalho, por motivo de maternidade, nascimento, incapacidade, invalidez, desemprego, prisão, idade avançada, tempo de serviço ou morte, mediante contribuição compulsória da sociedade e de cada um dos participantes.

Diante do caráter eminentemente contributivo da Previdência, o equilíbrio financeiro e atuarial $^{125}$ é critério essencial para a sua sustentabilidade, pois o balanceamento entre as contribuições vertidas e as concessões de benefícios deve convergir para que sistema não se torne deficitário.

O caput do artigo 201 da Constituição prevê não só o equilíbrio financeiro e atuarial como critério de sustentação do Regime Geral de Previdência, mas também a compulsoriedade na filiação, segundo a qual todos os trabalhadores que exerçam atividades remuneradas lícitas devem filiar-se ao regime e, por consequência, verter as contribuições incidentes sobre a sua remuneração.

É possível concluir, assim, que os pilares de sustentação da Previdência estão exatamente na contributividade e na compulsoriedade, lastreados sempre por uma necessidade de manutenção de equilíbrio financeiro e atuarial entre prestações pagas aos beneficiários do regime e custeio.

Fábio Zambitte Ibrahim $^{126}$ ensina de forma bastante sucinta que 0 equilíbrio financeiro pode ser definido como o saldo zero ou positivo decorrente do encontro entre receitas e despesas do sistema. Em outras palavras, a manutenção do seu adequado funcionamento no momento atual e futuro dependem do cumprimento de todas as obrigações pecuniárias, decorrentes de pagamentos de benefícios previdenciários, bem como de uma política sustentável de arrecadação por parte da administração pública, evitando, de toda forma, flutuações danosas ao equilíbrio de contas.

Por outro lado, o equilíbrio atuarial diz respeito à previsibilidade e controle das variações no universo de segurados. Assim, cabe à administração pública aferir os riscos sociais protegidos em contraposição aos recursos disponíveis,

\footnotetext{
125 "Art. 201 A previdência social será organizada sob a forma de regime geral, de caráter contributivo e de filiação obrigatória, observados critérios que preservem o equilíbrio financeiro e atuarial, e atenderá, nos termos da lei, a:"

${ }_{126}$ IBRAHIM, Fábio Zambitte. Curso de Direito Previdenciário. 16ª ed. rev., ampl. e atual. Rio de Janeiro: Impetus, 2011, p. 43.
} 
conjecturando a sua viabilidade em diversos cenários possíveis no futuro, especialmente em relação ao envelhecimento da população e às tendências da natalidade.

Havendo regularidade nas contribuições vertidas pelos segurados, emerge na teoria automaticamente o dever do Estado em prover o pagamento dos benefícios previstos no sistema previdenciário, uma vez que, em contrapartida à compulsoriedade do custeio, está a reciprocidade contributiva.

Cumpre-se destacar que dentre os princípios norteadores da Previdência Social, está o da contrapartida, segundo o qual nenhum benefício ou serviço da seguridade social pode ser criado, majorado ou estendido sem a correspondente fonte de custeio.

No que tange à contribuição do trabalhador, podemos dizer que não se pode subsistir salário de benefício sem o correspondente salário de contribuição. O salário de contribuição é composto pela parcela da remuneração do empregado susceptível de incidência da alíquota correspondente à sua parcela da contribuição social, limitada ao teto estabelecido pelo sistema previdenciário.

Por sua vez, o salário de benefício emerge da aplicação das regras de atualização dos salários de contribuição e é sobre ele que se fará incidir a alíquota referente ao benefício que está sendo concedido e o fator previdenciário, se for o caso.

Assim, fazendo uma lógica inversa, a reciprocidade na previdência social decorre do fato de que uma vez realizada a contribuição sobre parcela da remuneração do cidadão, obrigatório o seu computo para fins de apuração de tempo de serviço e valor do salário de benefício.

As prestações compreendidas pelo Regime Geral de Previdência Social são expressas principalmente em benefícios, os quais têm regras e requisitos próprios para a sua concessão.

Dentre os requisitos objetivos está a carência, instituto típico do contrato de seguro, em que se exige tempo ou número mínimo de parcelas para poder usufruir dos benefícios. Na previdência, considera-se carência o número mínimo de contribuições mensais indispensáveis para que o beneficiário faça jus ao percebimento de benefício.

O salário de benefício é a base de cálculo da renda mensal inicial de todos os benefícios oferecidos pelo Regime Geral de Previdência Social, 
composto pela média aritmética de certo número de salários de contribuição devidamente atualizados. Cumpre-se destacar que o salário de benefício não corresponde necessariamente ao valor do benefício, pois após a sua apuração ainda aplica-se a alíquota correspondente para se apurar a renda mensal à que o segurado fará jus enquanto beneficiário do sistema.

Conforme afirmado por Sérgio Pinto Martins ${ }^{127}$, o regulamento da previdência estabelece que o salário de benefício é o valor utilizado para se calcular a renda mensal inicial dos benefícios de prestação continuada, exceto salário-família, salário-maternidade, a pensão por morte e os demais benefícios da legislação especial.

No cálculo dos benefícios, o INSS se utiliza principalmente das informações inseridas no Cadastro Nacional de Informações Sociais (CNIS), criado em 1994, no qual devem constar os vínculos e as remunerações percebidas pelo segurado em sua vida laboral. Tais informações ainda servem como meio de prova de filiação ao Regime Geral de Previdência Social, tempo de contribuição e relação de emprego.

Conforme bem colocado por Carlos Henrique de Oliveira ${ }^{128}$, na composição do Cadastro Nacional de Informações Sociais estão envolvidos órgãos incumbidos da gestão dos direitos sociais, tendo sido criado com 0 objetivo de se tornar uma base de dados das informações essenciais para garantia de acesso aos direitos trabalhistas e previdenciários dos brasileiros. Essa iniciativa não só libera o trabalhador do ônus da prova no momento do requerimento de benefícios, como também inibe as fraudes nas suas concessões, que por anos corroem o sistema previdenciário e dilapidam o patrimônio público.

A principal fonte de informações do CNIS, até o presente momento, é a Guia de Informações do FGTS, a GFIP, sob os cuidados da Caixa Econômica Federal. Nos termos do artigo 32 da Lei no 8.212/91, as empresas estão obrigadas a informarem todos os dados referentes aos trabalhadores a elas vinculados, em especial, sobre tempo de serviço e remuneração paga, sendo inclusive de sua responsabilidade as providências de inscrição dos empregados na Previdência Social.

\footnotetext{
${ }^{127}$ MARTINS, Sérgio Pinto. Direito da Seguridade Social. 33ª ed. São Paulo: Atlas, 2013, p. 315. 128 OLIVEIRA, Carlos Henrique de. Da tutela das informações sociais do trabalhador à garantia efetiva de acesso aos benefícios previdenciários. 256 folhas. Tese - Universidade de São Paulo, Faculdade de Direito do Largo de São Francisco. São Paulo, janeiro de 2013, p. 147.
} 
A exceção que se faz em relação ao lançamento de informações no Cadastro Nacional de Informações Social via GFIP se dá em relação aos contribuintes individuais e aos empregados domésticos, os quais têm esses dados inseridos no sistema por meio dos recolhimentos mensais pela guia GPS. Destaca-se o fato que a legislação permite o recolhimento de FGTS para o trabalhador doméstico, quando feita essa opção, as informações também serão inseridas por meio da GFIP.

É garantido ao segurado da previdência solicitar, a qualquer tempo, a inclusão, exclusão ou retificação de dados constantes do Cadastro Nacional de Informações Sociais, mediante a apresentação de documentação comprobatória das divergências.

Dessa feita, diferente não deve ser quando da alteração das informações decorrentes de uma sentença trabalhista, que tenha como objeto a alteração de uma situação fática com reflexos nos registros previdenciários do beneficiário de sua eficácia.

Nesse contexto, o artigo 889-A da CLT traz a previsão para que os recolhimentos das importâncias devidas, referentes às contribuições sociais, sejam efetuados nas agências locais da Caixa Econômica Federal ou do Banco do Brasil S.A., por intermédio de documento de arrecadação da Previdência Social, dele se fazendo constar o número do processo.

É imprescindível que reste comprovado nos autos não somente o efetivo recolhimento da contribuição social mediante a utilização da guia apropriada, mas também o envio dessas informações ao banco de dados da receita previdenciária no sistema de Conectividade Social da Caixa Econômica Federal.

Vale destacar que a não comprovação nos autos de que as informações efetivamente chegaram ao conhecimento ao destinatário legal por meio do protocolo de envio da GFIP pode acarretar em prejuízo ao trabalhador em razão do não lançamento no Cadastro Nacional de Informações Sociais das informações relativas aos vínculos e as remunerações reconhecidas em sentença trabalhista, os quais, por consequência deixaram de ser considerados no cômputo do tempo de contribuição e no cálculo do salário de benefício. 
O inciso IV do artigo 32 da Lei ํㅜ 8.212/91 e o caput do artigo 105 da Instrução Normativa RFB no 971/2009 ${ }^{129}$ trazem em seu conteúdo normativo a determinação para que os fatos geradores de contribuições sociais decorrentes de reclamatória trabalhista sejam efetivamente informados em GFIP, mesmo que as correspondentes contribuições sociais sejam recolhidas em documento de arrecadação identificado com código de pagamento específico para esse fim.

Nos termos do artigo 29-A da Lei no 8.213/91, essa transmissão de informações relativas às contribuições vertidas pela GFIP é de suma importância na composição da base de dados do Cadastro Nacional de Informações Sociais, afinal, os vínculos e remunerações lançados serão utilizados para fins de cálculo e concessão dos benefícios previdenciários.

Importante ressaltar que a regulamentação das disposições constitucionais sobre a execução de ofício das contribuições sociais previstas no artigo 195, I, a, e II, e seus acréscimos legais, decorrentes das sentenças proferidas na justiça do trabalho se deram com o advento das Leis no 10.035/00 e ํo 11.941/2009. Senão, vejamos as alterações na Lei oํ 8.212/91:

Art. 43. Nas ações trabalhistas de que resultar o pagamento de direitos sujeitos à incidência de contribuição previdenciária, o juiz, sob pena de responsabilidade, determinará o imediato recolhimento das importâncias devidas à Seguridade Social. (Redação dada pela Lei $n^{\circ} 8.620$, de 5.1.93) $\S 10$ Nas sentenças judiciais ou nos acordos homologados em que não figurarem, discriminadamente, as parcelas legais relativas às contribuições sociais, estas incidirão sobre o valor total apurado em liquidação de sentença ou sobre o valor do acordo homologado. (Incluído pela Lei no 11.941, de 2009).

\section{$\S 20$ Considera-se ocorrido o fato gerador das contribuições sociais na} data da prestação do serviço. (Incluído pela Lei no 11.941 , de 2009).

$\S 30$ As contribuições sociais serão apuradas mês a mês, com referência ao período da prestação de serviços, mediante a aplicação de alíquotas, limites máximos do salário-de-contribuição e acréscimos legais moratórios vigentes relativamente a cada uma das competências abrangidas, devendo o recolhimento ser efetuado no mesmo prazo em que devam ser pagos os créditos encontrados em liquidação de sentença ou em acordo homologado, sendo que nesse último caso o recolhimento será feito em tantas

129 "Art. 105. Os fatos geradores de contribuições sociais decorrentes de reclamatória trabalhista deverão ser informados em GFIP, conforme orientações do Manual da GFIP, e as correspondentes contribuições sociais deverão ser recolhidas em documento de arrecadação identificado com código de pagamento específico para esse fim." 
parcelas quantas as previstas no acordo, nas mesmas datas em que sejam exigíveis e proporcionalmente a cada uma delas. (Incluído pela Lei oㅜ 11.941, de 2009).

$\S 40$ No caso de reconhecimento judicial da prestação de serviços em condições que permitam a aposentadoria especial após 15 (quinze), 20 (vinte) ou 25 (vinte e cinco) anos de contribuição, serão devidos os acréscimos de contribuição de que trata $\circ \S 60$ do art. 57 da Lei no 8.213 , de 24 de julho de 1991. (Incluído pela Lei no 11.941, de 2009).

$\S 50 \mathrm{Na}$ hipótese de acordo celebrado após ter sido proferida decisão de mérito, a contribuição será calculada com base no valor do acordo. (Incluído pela Lei oㅜ 11.941, de 2009).

$\S 60$ Aplica-se o disposto neste artigo aos valores devidos ou pagos nas Comissões de Conciliação Prévia de que trata a Lei no 9.958, de 12 de janeiro de 2000. (Incluído pela Lei no 11.941, de 2009).

(grifos nossos)

Carlos Henrique de Oliveira ${ }^{130}$ afirma que podemos verificar claramente na norma infraconstitucional uma determinação para que o juiz do trabalho, sob pena de responsabilidade, defina o imediato recolhimento das importâncias devidas à Seguridade Social. Outrossim, que é de interesse das partes a discriminação das verbas remuneratórias e indenizatórias, posto que a primeira, tendo natureza salarial, é fundamental para a composição das informações previdenciárias.

Destaca-se ainda o fato de que a norma estabelece claramente que o momento de ocorrência do fato gerador é a data da efetiva prestação do serviço, entretanto, isso não foi suficiente para colocar uma pá de cal sobre a controvérsia.

O que interessa para fins de concessão de benefício é que a morosidade do processo, dependendo da corrente que se segue, pode culminar com a extinção do crédito tributário e, por consequência, dispensar o recolhimento das contribuições sociais decorrentes da incidência da norma jurídica pela sentença trabalhista, ou seja, não serão inseridas quaisquer informações por meio de GFIP no Cadastro Nacional de Informações Sociais e, em razão disso, o segurado pode ser prejudicado pela falta de eficiência da administração pública na constituição de seu crédito.

${ }^{130}$ OLIVEIRA, Carlos Henrique de. Da tutela das informações sociais do trabalhador à garantia efetiva de acesso aos benefícios previdenciários. 256 folhas. Tese - Universidade de São Paulo, Faculdade de Direito do Largo de São Francisco. São Paulo, janeiro de 2013, p. 181. 
Conforme asseverado pelo Procurador Federal luri Cardoso de Oliveira ${ }^{131}$, pelo menos $1 / 6$ (um sexto) das Corregedorias Regionais do Trabalho já produziu alguma norma com a finalidade de promover a apresentação de GFIP com a descrição dos fatos geradores de contribuições sociais decorrentes de reclamatória trabalhista.

Essa medida é de suma importância para o provimento de informações no CNIS, ao passo que tanto as demais Corregedorias Regionais quanto a Corregedoria-Geral da Justiça do Trabalho mantêm-se silentes sobre a matéria.

Do mesmo modo, existe um óbice de ordem prática para as decisões judiciais no que pertine à determinação de comprovação da inscrição do trabalhador no INSS e o recolhimento das contribuições previdenciárias de todo o período trabalhado, mediante apresentação do protocolo de entrega da GFIP, trata-se da necessidade ou não de pré-existência de pedido expresso do autor da ação nesse sentido.

Estabelece o artigo 128 do Código de Processo Civil que o juiz decidirá a lide nos limites em que foi proposta, sendo-lhe defeso conhecer a respeito de questões, não suscitadas, em que a lei exige a iniciativa da parte. Igualmente, o artigo 460 do mesmo diploma legal, inserido no capítulo que trata da sentença, mais especificamente na seção dos requisitos e efeitos da sentença, que dispõe ser defeso ao juiz proferir sentença, a favor do autor, de natureza diversa da pedida, bem como condenar o réu em quantidade superior ou em objeto diverso do que Ihe foi demandado.

Estamos diante do princípio da congruência, segundo o qual o magistrado da causa não pode decidir de maneira ultra, citra ou extra petita, sob pena de ver sua decisão reformada em razão da ausência de vinculação com a causa de pedir e pedido.

Nesse contexto, a $1^{\text {a }}$ Turma do Tribunal Superior do Trabalho ${ }^{132}$, ao julgar o recurso de revista $\mathrm{n}^{0}$ 56700-85.2006.5.08.0115, de relatoria do Ministro Lelio

131 OLIVEIRA, luri Cardoso de. GFIP trabalhista e alimentação da base de dados do Cadastro
Nacional de Informações Sociais. Conteúdo Jurídico, Brasilia-DF: 17 maio 2012 . Disponível em:
<http://www.conteudojuridico.com.br/?artigos\&ver=2.37005\&seo=1>. Acesso em: 16 nov. 2014 .
"COMPETÊNCIA MATERIAL DA JUSTIÇA DO TRABALHO. ENTE PÚBLICO.
CONTRATAÇÃO IRREGULAR. REGIME ESPECIAL. DESVIRTUAMENTO. "I - Inscreve-se na
competência material da Justiça do Trabalho dirimir dissídio individual entre trabalhador e ente
público se há controvérsia acerca do vínculo empregatício. II - A simples presença de lei que
disciplina a contratação por tempo determinado para atender a necessidade de excepcional
interesse público (art. 37 , inciso IX, da CF/1988) não é o bastante para deslocar a competência da 
Bentes Corrêa, reformou a decisão do magistrado de primeiro grau, firmando entendimento no sentido de que se trata de julgamento extra petita a determinação para que o reclamado comprove nos autos a inscrição do reclamante ao INSS e o recolhimento das contribuições previdenciárias de todo o período trabalhado, mediante GFIP, sem que haja pedido expresso e específico do autor na petição inicial.

Sob o aspecto pragmático da questão, um maior cuidado dos patronos dos reclamantes nas reclamatórias trabalhistas poderia sanar ou, ao menos, minimizar o problema ${ }^{133}$, garantindo, de certa forma, a incidência dos efeitos previdenciários nas sentenças trabalhistas.

Acontece que, isso não soluciona de uma vez por todas o problema, na medida em que se daria tratamento diferenciado aos reclamantes em razão do pedido formulado por seus advogados, e em contrapartida 0 aspecto arrecadatório estaria garantido pelo sistema jurídico em razão do dever de execução de ofício da contribuição social pelos magistrados trabalhistas.

Justiça do Trabalho se se alega desvirtuamento em tal contratação, mediante a prestação de serviços à Administração para atendimento de necessidade permanente e não para acudir a situação transitória e emergencial". Hipótese de incidência da Orientação Jurisprudencial n. 205 da SBDI-I desta Corte superior. Recurso de revista não conhecido. NULIDADE. CONTRATO CELEBRADO COM ENTE PÚBLICO NA VIGÊNCIA DA CONSTITUIÇÃO FEDERAL DE 1988, SEM PRÉVIA APROVAÇÃO DO RECLAMANTE EM CONCURSO PÚBLICO. REGIME ESPECIAL DESCARACTERIZADO. EFEITOS DO CONTRATO. SÚMULA N. 363 DO TRIBUNAL SUPERIOR DO TRABALHO. "A contratação de servidor público, após a Constituição Federal de 1988, sem prévia aprovação em concurso público, encontra óbice no respectivo art. 37 , II e $\S 2^{\circ}$, somente lhe conferindo direito ao pagamento da contraprestação pactuada, em relação ao número de horas trabalhadas, respeitado o valor da hora do salário mínimo, e dos valores referentes aos depósitos do FGTS" (Súmula n.. 363 desta Corte superior). Referida súmula respalda o decidido no acórdão prolatado em sede de recurso ordinário. Recurso de revista não conhecido. PRESCRIÇÃO. PREQUESTIONAMENTO. SÚMULA N ‥ 297, I, DO TST. A ausência de pronunciamento, por parte da Corte de origem, acerca de elemento essencial à tese veiculada no apelo torna inviável o seu exame, à míngua do indispensável prequestionamento. Hipótese de incidência do entendimento cristalizado na Súmula n. - 297, I, desta Corte superior. Recurso de revista não conhecido. JULGAMENTO EXTRA PETITA. A Corte regional, ao determinar, sem que tenha havido pedido expresso e específico do autor na peticão inicial, que o reclamado comprovasse a inscricão do reclamante junto ao INSS e o recolhimento das contribuicões previdenciárias de todo o período trabalhado, mediante GFIP, incorreu em julgamento extra petita por extrapolar os limites da pretensão deduzida em juízo. Violacão dos artigos 128 e 460 do Código de Processo Civil que se reconhece configurada. Recurso conhecido e provido. (RR 56700-85.2006.5.08.0115, Relator Ministro: Lelio Bentes Corrêa, Data de Julgamento: 15/10/2008, 1 a Turma, Data de Publicação: 31/10/2008) (grifos nossos)

${ }^{133}$ Os advogados que militem na área trabalhista devem criar o hábito de, além dos pedidos inerentes aos direitos trabalhistas, formular expressamente pedido de condenação do reclamado nas obrigações de preencher e enviar a GFIP trabalhista, bem como de juntar nos autos o protocolo de envio gerado pelo sistema SEFIP, para provimento de informações do CNIS." 


\subsection{A Reciprocidade Contributiva e a Execução de Ofício}

Enfrentadas todas as questões atinentes à natureza jurídica da contribuição devida à seguridade social e à abordagem científica da forma de constituição desse crédito por meio de sentença trabalhista, importante abordar a finalidade social da norma previdenciária, sob o prisma do princípio da dignidade humana.

Nesse sentido, é preciso identificar se estaria inserida no ordenamento constitucional alguma regra atinente ao reconhecimento da sentença trabalhista para fins de comprovação de tempo de serviço e obtenção de benefício previdenciário.

É de conhecimento comum o fato de que, em que pese possuir a competência jurisdicional para executar ex officio as contribuições sociais, a Justiça do Trabalho não goza, na prática, da mesma autonomia para fins de determinação da averbação do período reconhecido no curso do processo no INSS.

A própria Turma Nacional de Uniformização dos Juizados Especiais Federais, ratificando tal entendimento, editou a Súmula $31^{134}$, segundo a qual a sentença trabalhista homologatória de acordo constitui mero início de prova material, ainda que tenha sido providenciado o efetivo recolhimento previdenciário do período homologado.

Igualmente, a anotação na CTPS do empregado realizado por meio de processo trabalhista, somente tem passagem liberada na esfera da Justiça Federal Previdenciária, se o INSS participar da lide, assim já decidiu o Superior Tribunal de Justiça ${ }^{135}$.

Entretanto, ainda que o INSS não seja parte propriamente dita na ação trabalhista, passará a participar do processo como terceiro interessado no momento da execução das verbas previdenciárias, podendo, inclusive, interpor recurso quando entender que não está satisfeita a obrigação por completo.

\footnotetext{
134 "A anotação na CTPS decorrente de sentença trabalhista homologatória constitui início de prova material para fins previdenciários." (DJ DATA:13/02/2006. PG:01043).

135 "(...) Não tendo a Previdência Social participado da lide trabalhista aventada, não pode sofrer as conseqüências da demanda. O reconhecimento do tempo de serviço exercido pelo autor em atividade urbana não se encontra amparado pelo início de prova documental, como dispõe a legislação previdenciária" (Res. 396.386/RN - 2001/0171111-4 - Rel. Min. Jorge Scartezzini - DJ 2/6/2003).
} 
A autarquia previdenciária, ainda, tomando conhecimento do processo trabalhista, perante o princípio da eficiência e seu poder/dever de fiscalização, deveria providenciar o lançamento do crédito tributário-previdenciário que entende ser devido em relação àquela relação de trabalho reconhecida judicialmente e, se for o caso, executá-lo na justiça federal competente.

Assim, com o reconhecimento de vínculo de emprego entre as partes de uma demanda judicial trabalhista e determinação do respectivo recolhimento previdenciário, passou a existir, necessariamente, a vinculação previdenciária do decisum.

De toda sorte, essa incoerência do sistema legal de execução trabalhista de crédito previdenciário em face ao seu não reconhecimento para fins de obtenção de benefício, deu causa à edição da Instrução Normativa ํo 95, de outubro de 2003, que estabeleceu os critérios a serem adotados pelas áreas de Benefícios do INSS quando tomarem conhecimento de situações de reconhecimento trabalhista de vínculo empregatício ${ }^{136}$.

Seguindo essa linha, podemos presumir que a própria Instrução Normativa $n^{\circ}$ 95/03, criada pelo INSS exige que os seus procuradores se

136 "Art. 105. [...]§ 4ํNa concessão ou revisão de aposentadoria por tempo de contribuição ou qualquer outro benefício do RGPS, sempre que for utilizado tempo de serviço/contribuição ou salário-de-contribuição decorrente de Ação Trabalhista, o processo deverá ser encaminhado para análise da Chefia de Benefícios da APS, devendo ser observado se:

I - na contagem de tempo de serviço/contribuição, ainda que tenha havido recolhimento de contribuições:

a) (...);

b) o INSS manifestou-se no processo judicial acerca do início de prova material, atendendo-se ao contraditório;

c) constatada a inexistência de documentos contemporâneos que possibilitem a comprovação dos fatos alegados, o período não poderá ser computado;

d) nas situações em que a documentação juntada ao processo judicial permita o reconhecimento do período pleiteado, caberá o cômputo desse período;

e) nos casos previstos na alínea c deste inciso, se constatado que o INSS manifestou-se no processo judicial acerca da prova material, a Chefia de Benefícios da APS deverá emitir um relatório fundamentado e enviar o processo para a Procuradoria local analisar, ficando pendente a decisão em relação ao cômputo do período;

f) após a concessão do benefício, se não houve recolhimento de contribuições, o processo deverá ser encaminhado para o Setor de Receita Previdenciária, para as providências a seu cargo.

II - no cômputo de salário-de-contribuição:

a) o processo deverá ser encaminhado para o Setor da Receita Previdenciária, para verificação e parecer sobre o referido recolhimento;

b) serão considerados os valores constantes da ação trabalhista transitada em julgado, desde que tenha havido o recolhimento das contribuições previdenciárias devidas à Previdência Social. (grifos nossos) 
manifestem nas ações trabalhistas que vierem a ter reflexos no direito previdenciário $^{137}$.

Talvez, o ideal fosse que a autarquia participasse como litisconsorte ativo necessário ou terceiro interessado desde a fase de conhecimento da lide, conferindo-se a sentença trabalhista maior eficácia para fins previdenciários.

Também merecem destaque os casos em que existir apenas uma sentença trabalhista declaratória de existência de vínculo, sem o correspondente recolhimento previdenciário, quando o crédito previdenciário houver sido corroído pela decadência ou pela prescrição ou quando existir um acordo homologado. Como fica o segurado diante do disposto no artigo 216 do Regulamento da Previdência $^{138}$ ?

Segundo a redação do referido dispositivo e em razão dos princípios norteadores da previdência social e os direitos e garantias fundamentais do cidadão, não pode ser o segurado penalizado pela conduta omissa do empregador e, muito menos, pela inércia da autarquia previdenciária no seu dever de fiscalização.

Diante das questões de reciprocidade contributiva inerente ao direito tributário, a autorização para que o magistrado trabalhista execute de ofício a contribuição previdenciária desacompanhada da mesma autonomia para fazer valer as consequências jurídicas dessa contribuição perante o INSS, reforça a

\footnotetext{
${ }^{137}$ FRACARO, Vandir. O Efeito da Sentença Trabalhista no Direito Previdenciário. Disponível em http://www.administradores.com.br/informe-se/artigos/o-efeito-da-sentenca-trabalhista-nodireito-pevidenciario/34761/, acesso em 17/10/2011.

138 "Art. 216. A arrecadação e o recolhimento das contribuições e de outras importâncias devidas à seguridade social, observado o que a respeito dispuserem o Instituto Nacional do Seguro Social e a Secretaria da Receita Federal, obedecem às seguintes normas gerais:

I - a empresa é obrigada a:

a) arrecadar a contribuição do segurado empregado, do trabalhador avulso e do contribuinte individual a seu serviço, descontando-a da respectiva remuneração; (Redação dada pelo Decreto no 4.729, de 2003).

b) recolher o produto arrecadado na forma da alínea "a" e as contribuições a seu cargo incidentes sobre as remunerações pagas, devidas ou creditadas, a qualquer título, inclusive adiantamentos decorrentes de reajuste salarial, acordo ou convenção coletiva, aos segurados empregados, contribuinte individual e trabalhador avulso a seu serviço, e sobre o valor bruto da nota fiscal ou fatura de serviço, relativo a serviços que the tenham sido prestados por cooperados, por intermédio de cooperativas de trabalho, até o dia vinte do mês seguinte àquele a que se referirem as remunerações, bem como as importâncias retidas na forma do art. 219, até o dia vinte do mês seguinte àquele da emissão da nota fiscal ou fatura, antecipando-se o vencimento para o dia útil imediatamente anterior quando não houver expediente bancário no dia vinte; (Redação dada pelo Decreto no 6.722, de 2008).

c) recolher as contribuições de que trata o art. 204, na forma e prazos definidos pela legislação tributária federal; (Redação dada pelo Decreto oㅡ 4.729, de 2003)."
} 
dificuldade em se buscar o fundamento de validade da norma tributária introduzida por sentença trabalhista.

O fato é que a sentença trabalhista, ainda que condenatória e decorrente de uma instrução processual bem formulada, mediante a apreciação de provas e análise fática da questão, é reconhecida pelo Direito Previdenciário como mero início de prova material, sendo necessário que o segurado promova, para fins de averbação desses períodos no INSS, nova produção probatória de acordo com o regramento específico.

Nesse sentido, a lição de Hermes Arais Alencar $^{139}$, segundo o qual para que seja possível a alteração do cadastro mantido pela previdência social, para que surta efeito na obtenção de benefícios previdenciários, exige-se a apresentação de documentos contemporâneos ao fato que se pretende comprovar, denominado início de prova material.

A sentença trabalhista, por razões óbvias, jamais será um documento contemporâneo aos fatos sociais suscetíveis de incidência da norma previdenciária, uma vez que, por regra, são as consequências da não aplicação do direito no momento oportuno em desfavor da parte prejudicada (trabalhador), que somente poderá reclamar o provimento jurisdicional de correção do ilícito trabalhista, cujas consequências afetam também na contagem de tempo e valor de benefício do empregado, após a consolidação destes. Em razão disso, por si só, as decisões trabalhistas não produzem efeito previdenciário.

Ademais, o disposto no artigo 472 do Código de Processo Civil ${ }^{140}$ também $^{1}$ poderia criar um óbice para a aceitação da sentença trabalhista como meio de comprovação da filiação dos segurados, visto que a coisa julgada produz seus efeitos apenas entre as partes integrantes do processo, não beneficiando nem prejudicando terceiros.

O INSS, no caso, apesar de participar da lide quando da execução da contribuição social, não é parte no processo de conhecimento, não lhe sendo conferido o direito de apresentar qualquer impugnação aos fatos discutidos no

\footnotetext{
${ }^{139}$ ALENCAR, Hermes Arrais. Benefícios Previdenciários. 4a ed. São Paulo: LEUD, 2011, p. 430.

140 "Art. 472. A sentença faz coisa julgada às partes entre as quais é dada, não beneficiando, nem prejudicando terceiros. Nas causas relativas ao estado de pessoa, se houverem sido citados no processo, em litisconsórcio necessário, todos os interessados, a sentença produz coisa julgada em relação a terceiros."
} 
mérito trabalhista. Cabendo-Ihe tão somente a discussão do quantum debeatur fiscal-previdenciário decorrente da decisão transitada em julgado.

Assim, também entende Simone Barbisan Fortes ${ }^{141}$, não obstante concluir que ausente qualquer indício de fraude, a sentença trabalhista deve, sim, produzir efeitos previdenciários.

Nesse ponto, importante verificar como se deu a prolação da sentença trabalhista, se se trata de uma homologação de acordo, se esse acordo se deu após ou antes a produção das provas, quais as provas produzidas, se houve 0 reconhecimento de vínculo, se a sentença é meramente declaratória, se é condenatório com apreciação de mérito e garantia da ampla defesa do reclamado, se a condenação se deu em razão da revelia do reclamado, entre outras possibilidades. Todos esses aspectos podem influenciar na atribuição qualitativa de valor probatório da sentença.

Qualquer que seja o critério de valoração qualitativa da sentença trabalhista enquanto meio de prova perante o INSS para fins de averbação de tempo de serviço e salários de contribuição, importante destacar que o vínculo reconhecido se deu na presença e pela intervenção de um juiz togado, investido de jurisdição, vinculado ao ordenamento jurídico e a todas as formalidades do processo judicial.

Quando diante de uma decisão condenatória, a situação é ainda mais convergente em favor do segurado, posto que esse magistrado competente,

\footnotetext{
141 "As reclamatórias, quando apenas visam a declarar a relação de emprego, com o único propósito de uma ação previdenciária futura, não valem como início de prova material. Tal entendimento ampara-se na idéia de que em alguns casos há simulação entre empregado e empregador, apenas no intuito do reconhecimento do vínculo para a concessão de benefício junto à Previdência Social.

Tal circunstância deve-se, de um lado, ao fato de que, diversamente do que ocorre no âmbito trabalhista, a comprovação de tempo de serviço para efeitos previdenciários, nos termos do art. 55 , § 20 , da Lei 8.213/91, demanda início de prova material, ou seja, impõe um tipo de prova tarifada, sem a qual, embora se conheça relação com efeitos trabalhistas, não opera ela somatório de tempo de serviço com vínculo previdenciário.

De outro lado, como o instituto previdenciário não participa da lide trabalhista, dada a limitação da eficácia subjetiva da coisa julgada, não pode sofrer os efeitos da sentença proferida na reclamatória trabalhista. Isso porque não the foi concedido o contraditório e ampla defesa, consoante assegurado pela $\mathrm{CF} / 88$.

Nada obstante, em havendo início de prova material a amparar o reconhecimento do tempo de serviço, bem como inexistindo o intuito fraudulento, por óbvio que o resultado das reclamatórias trabalhistas assumem, no âmbito previdenciário - em especial nas ações judiciais que versam sobre reconhecimento de tempo de serviço previdenciário - posição bastante privilegiada, configurando elemento bastante forte de convencimento". (Direito da Seguridade Social: prestações e custeio da previdência, assistência e saúde. Porto Alegre: Livraria do Advogado, 2005, p. 182-183).
} 
convencido da matéria fática pelos meios de prova admitidos em direito, prolata decisão que deve produzir seus efeitos no mundo jurídico em geral, principalmente após the ter sido atribuído pelo texto constitucional a competência executória das contribuições devidas à Seguridade Social decorrente de suas sentenças.

Em outras palavras, como consequência lógica da reciprocidade contributiva, se o magistrado trabalhista arrecada em favor do fisco previdenciário, se o INSS não apresenta impugnação ao valor recolhido, se há no processo o reconhecimento de vínculo ou de qualquer outro fato que deva alterar a situação cadastral do reclamante na previdência, imperativa a atribuição de eficácia previdenciária à sentença trabalhista e outorga de competência ao magistrado do trabalho para, também de ofício, determinar a averbação do tempo, do salário ou da especialidade da profissão no Cadastro Nacional de Informações Sociais.

O artigo 55, da Lei ํ․ 8.213/91, mostra-se, portanto, inconstitucional, na medida em que condicionar a eficácia da sentença trabalhista transitada em julgado à apresentação de outras provas do fato trabalhista com implicações previdenciárias, para que assim possa produzir seus efeitos com a previdência social, além de prejudicar a parte mais fraca dessa relação jurídica (o trabalhador/segurado), ainda se mostra um contrassenso ao comando constitucional arrecadatório ex officio atribuído ao magistrado trabalhista.Poderíamos, assim, cair na esdrúxula hipótese em que haja o efetivo recolhimento da contribuição social e, por consequência, seja saciada a ânsia arrecadatória fiscal e mesmo assim o direito reconhecido judicialmente não surtirá efeitos em sua plenitude se esse vínculo empregatício não contar para fins de tempo de contribuição, carência, filiação etc.

Analisando a hipótese sob a ótica da incidência normativa, que tem sido o prisma de estudo no presente trabalho, podemos até invocar a teoria de Enrico Tullio Liebman ${ }^{142}$, que entende que a sentença, enquanto ato de Estado, tem uma eficácia natural perante terceiros.

\footnotetext{
142 "A sentença, como ato de autoridade ditado por um órgão do Estado, reivindica naturalmente, perante todos, seu ofício de formular o comando concreto da lei ou, mais genericamente, a vontade do Estado, para um caso determinado.

As partes, como sujeitos da relação à que se refere a decisão, são certamente as primeiras que sofrem sua eficácia, mas não há motivo que exima os terceiros de sofrê-la igualmente. (...)
} 
Para o autor, a sentença reivindica naturalmente seu ofício de formular o comando concreto da lei ou a vontade do Estado diante de uma situação que lhe é colocada para decisão. Logicamente, as partes do processo, que são sujeitos da relação jurídica, são as primeiras a sofrerem as consequências do trânsito em julgado da decisão.

Entretanto, nada impede que a sentença também produza seus efeitos naturalmente perante terceiros, em que a única diferença reside no fato de que em relação aos litigantes, após o trânsito em julgado, ela se torna imutável, já para os terceiros, em face da possibilidade de erro, existe uma série de remédios para evitá-los e repará-los.

Nesse contexto, poderíamos dizer que as normas jurídicas inseridas nas Leis de Custeio e Benefício estão interligadas, portanto, a incidência fiscal por meio de sentença trabalhista, decorrente da autorização constitucional, acarreta em reflexos automáticos e naturais no que se refere à inserção de dados no Cadastro Nacional de Informações Sociais, principalmente diante da natureza tributária da contribuição social, que implica na aplicação do princípio da reciprocidade contributiva, que, no sistema da Seguridade Social, só se materializa na concessão de benefícios previdenciários, por ser única vertente que depende do prévio custeio.

E mais, segundo a corrente encabeçada por Liebman, ainda que os efeitos da coisa julgada trabalhista não produzam seus efeitos perante o INSS, em razão de ser parte estranha à lide, a sentença, enquanto ato do Estado produz efeitos naturais perante todos e deve ser respeitada.

Segundo essa teoria, aplicando-se no caso específico da execução de ofício das contribuições sociais, no que se relaciona à inserção de dados no Cadastro Nacional de Informações Sociais, criando uma verdadeira regra de inversão do ônus da prova, na medida em que, por haver de respeitar a ordem

Entre partes e terceiros só há esta grande diferença: que para as partes, quando a sentença passa em julgado, os seus efeitos se tornam imutáveis, ao passo que para os terceiros isso não acontece. (...)

Por certo o juiz, ao decidir, pode cometer erros, e é esta uma hipótese que a lei prevê e considera, estabelecendo uma série de garantias e remédios para evitar e reparar os erros. (...)

A eficácia da sentença, considerada independentemente da autoridade da coisa julgada, está subordinada à sua conformidade com o direito; mas esta se presume, e só uma efetiva demonstração da sua falta impede a sentença de produzir em concreto o seu efeito natural e normal." (LIEBMAN, Enrico Tullio. Eficácia e Autoridade da Sentença. Rio de Janeiro, 1945, Editora Forense, p. 105-122). 
estatal, o INSS é que deve se movimentar no sentido de provar que o fato declarado na reclamatória trabalhista não corresponde à realidade e, portanto, não deve surtir efeitos previdenciários.

Assim, se o segurado for a juízo em razão da negativa de benefício pelo não reconhecimento de período reconhecido por sentença trabalhista, este não teria de produzir outras provas, apenas executar o comando natural inserido naquele documento.

O INSS, muitas vezes, deixa de reconhecer o vínculo e, ainda, quando instado judicialmente a se manifestar em âmbito da Justiça Federal, argumenta um suposto desprestígio da prova produzida no reconhecimento do direito na trabalhista. Essa postura, na teoria de Liebman, afronta a efetividade da tutela jurisdicional, na medida em que um mesmo fato recebe tratamento diverso e por autoridade, a qual supostamente estaria adstrita ao entendimento emanado judicialmente.

A problemática de maior incidência está nas decisões judiciais nas quais se reconhece o vínculo trabalhista outrora desprezado pelo empregador. Nesses casos, mesmo havendo a determinação de recolhimento da contribuição social no próprio processo do trabalho, o INSS insiste em não reconhecer o período e as remunerações para fins e concessão de benefício.

O judiciário, em que pese não adotar plenamente a teoria de Lieban, entende que, quando fundada em documentos que demonstrem o exercício da atividade laborativa na função e períodos alegados na ação previdenciária, a sentença trabalhista constitui início de prova material, sendo irrelevante o fato de que a autarquia previdenciária não ter integrado aquela lide ${ }^{143}$.

143 "PREVIDENCIÁRIO. PROCESSUAL CIVIL. SENTENÇA TRABALHISTA FUNDAMENTADA EM PROVA MATERIAL. VALOR PROBANTE DE INÍCIO DE PROVA MATERIAL. APOSENTADORIA POR TEMPO DE CONTRIBUIÇÃO. HONORÁRIOS ADVOCATÍCIOS. JUROS MORATÓRIOS. CORREÇÃO MONETÁRIA. CUSTAS. 1. O STJ vem, de forma reiterada, decidindo no sentido de que a sentença trabalhista pode ser considerada como início de prova material, estando apta para comprovar o tempo de serviço prescrito no art. 55, $\S 3^{\circ}$, da Lei $8.213 / 1991$, desde que fundamentada em elementos que demonstrem o exercício da atividade laborativa na função e nos períodos alegados, ainda que o Instituto Previdenciário não tenha integrado a respectiva lide. 2. Os elementos dos autos demonstram a ocorrência do vínculo laboral como empregado segurado obrigatório do RGPS, estando apta para comprovar o tempo de serviço prescrito no indigitado art. 55 , § $3^{\circ}$, da Lei $8.213 / 1991$, considerando que a parte autora acostou aos autos os contracheques do período que pretende ver reconhecido, inclusive com desconto de verba previdenciária. (fls. 53/123). 3. A jurisprudência vem admitindo a sentença trabalhista como prova iuris tantum ou início de prova material do tempo objeto da reclamação trabalhista. Frise-se que o c. STJ diz da necessidade de haver outros elementos, sem esclarecer os quais, mas já admitiu como prova a sentença proferida na Justiça Trabalhista após a regular instrução do feito. 4. Verifica-se que a 
A Turma Nacional de Uniformização dos Juizados editou em 2006 a Súmula $n^{\circ} 31$, segundo a qual a anotação na CTPS decorrente de sentença trabalhista homologatória constitui início de prova material para fins previdenciários. Vejam, que a Turma Nacional de Uniformização faz menção à sentença homologatória enquanto meio de prova para fins previdenciários, o que é ainda mais abrangente.

Acontece que, na prática, tanto os Juizados Especiais, quanto a Justiça Federal Comum e Previdenciária admitem a sentença trabalhista enquanto meio de prova, mas desde que corroborada com outras que possam confirmar aquilo que já foi reconhecido judicialmente.

Destaca-se aqui o fato que, mesmo diante de uma decisão transitada em julgado, proferida por um juiz togado e investido de jurisdição, caso esta não seja confirmada por outras provas, às vezes, as mesmas já produzidas em audiência trabalhista, a sentença não terá eficácia previdenciária.

Não é incomum que em processo que tramitam na Justiça Federal, nos quais se discuta a utilização de períodos reconhecidos em sentença trabalhista para obtenção de um benefício previdenciário, o juiz federal produza novamente a mesma oitiva testemunhal realizada pelo juiz do trabalho. Isso não nos parece fazer muito sentido, indo de encontro ao princípio da economia processual, inclusive.

A Justiça Federal, em que pese não haver em nosso ordenamento jurídico a fixação de critério de valoração e hierarquia entre as provas legalmente em direito admitidas, ainda desprestigia a prova oral, e em diversos julgados verificamos essa situação colocada de forma sutil, porém decisiva, no momento

autora, nascida em 21/12/1938 (fl. 27), completou 60 anos de idade em 21/12/1998, preencheu o requisito etário para a concessão da aposentadoria por idade urbana pleiteada. 5 . Preenchidos os requisitos exigidos pela Lei 8.213/1991, é de ser concedida à autora a aposentadoria por idade, a partir do requerimento administrativo. 6. Esta Corte estabilizou o entendimento de que são devidos na ordem de $10 \%$ sobre o valor da condenação, correspondente às parcelas vencidas até o momento da prolação da sentença, de acordo com a Súm. 111, do STJ e art. 20, § 3ํ, do CPC. 7. Atrasados desde a citação, conforme fixado na sentença, e a implantação do benefício: a) Correção monetária pelo MCJF; b) os juros moratórios são devidos no percentual de $1 \%$ a.m. até a edição da Lei 11.960/2009, quando então serão devidos no percentual de 0,5\% a.m. conforme são aplicados nas cadernetas de poupança. Contam-se da citação, para as parcelas eventualmente vencidas anteriormente a ela, e do respectivo vencimento, para as que Ihe são posteriores. 8. O INSS é isento de custas processuais, de acordo com a Lei 9.289/1996. 9. Apelação da autora provida, em parte, nos termos do item 6. 10. Apelação do INSS parcialmente provida (item 8). 11. Remessa oficial, em parte provida, nos moldes do item 7"; (TRF da 1ㄹ Região, AC 2008.33.00.012983-1/BA, 2a T., Rel.: Juiz Fed. CLEBERSON JOSÉ ROCHA (conv.), j. em 15/4/2013, e-DJF1 08/5/2013) 
de se aplicar a norma previdenciária com base em sentença trabalhista lastreada exclusivamente na prova testemunhal ${ }^{144}$.

Essa posição muito se dá em razão do disposto no parágrafo $3^{\circ}$ do artigo 55 da Lei n 8.213/91, ao qual estabelece que a comprovação do tempo de contribuição mediante justificação administrativa ou judicial só produz efeito quando baseada em início de prova material, não sendo admitida prova exclusivamente testemunhal, salvo na ocorrência de motivo de força maior ou caso fortuito, conforme disposto no Regulamento.

Entretanto, admitir esse entendimento de forma indiscriminada causa prejuízo à parte mais fraca dessa relação, o trabalhador, na maioria das vezes, litiga durante anos para ver reconhecido o seu vínculo trabalhista e, após alcançar o pretendido, precisam passar novamente por longos anos discutindo a mesma relação perante a Justiça Federal para finalmente usufruírem dos efeitos previdenciários da relação laboral.

Aqueles que defendem a tese de que as sentenças trabalhistas são ineficazes perante o INSS argumentam a possibilidade de utilização da reclamação trabalhista não como instrumento de solução do litígio entre empregado e empregador, mas como verdadeiro subterfúgio para obter um título judicial oponível em face da Previdência Social. A produção de efeitos previdenciários automáticos, na visão de quem acha ser prudente e necessário um novo crivo de apuração dos fatos decididos em ambiente trabalhista, trabalha com a possibilidade de simulação nas reclamatórias, principalmente aquelas em

144 "PROCESSUAL CIVIL. PREVIDENCIÁRIO. AGRAVO DE INSTRUMENTO. TUTELA ANTECIPADA. NULIDADE POR FALTA DE FUNDAMENTAÇÃO. NÃO OCORRÊNCIA. SENTENÇA TRABALHISTA BASEADA APENAS EM PROVA TESTEMUNHAL. EXERCÍCIO DE ATIVIDADE NA FUNÇÃO E NO PERÍODO DECLARADO NÃO COMPROVADO. AGRAVO IMPROVIDO. 1. De acordo com o artigo 273 do CPC, o juiz pode antecipar os efeitos da tutela pretendida desde que, havendo prova inequívoca, se convença da verossimilhança da alegação e haja fundado receio de dano irreparável ou de difícil reparação. 2. A agravante requereu no juízo a quo, liminarmente, que o INSS deferisse seu benefício de pensão por morte, tendo por base o fundamento de que a anotação decorrente de sentença trabalhista constituiria prova suficiente do tempo de serviço de seu cônjuge. 3. No caso, da análise da referida sentenca às fls. $73 / 75$, verifica-se que suas conclusões foram tomadas com base apenas no depoimento pessoal do demandante e de suas duas testemunhas, carecendo, portanto, de provas que comprovem, com maior robustez, o exercício de atividade na funcão e no período contratado. 4. Do exposto, tendo em conta a inexistência de qualquer documentação a evidenciar o exercício da atividade laborativa declarada, não se presta para esse fim, em sede de tutela antecipada, apenas a sentença trabalhista baseada em prova exclusivamente testemunhal, razão pela qual, nego provimento ao agravo de instrumento." (TRF-5 - AGTR: 83533 PB 008917060.2007.4.05.0000, Relator: Desembargador Federal Emiliano Zapata Leitão (Substituto), Data de Julgamento: 5/2/2009, Primeira Turma, Data de Publicação: Fonte: Diário da Justiça - Data: 18/3/2009 - Página: 450 - №: 52 - Ano: 2009) (grifos nossos). 
que não há condenação, posto que o empregado de comum acordo com o empregador poderia buscar uma sentença com a finalidade específica de obtenção de benefícios previdenciários.

Seguindo essa linha, o fato do INSS não haver integrado a lide e a suposta incompetência da Justiça do Trabalho para apreciar as questões relativas à inserção de dados no Cadastro Nacional de Informações Sociais impossibilitam a incidência dos efeitos previdenciários como decorrência lógica do objeto da ação trabalhista.

Contudo, não parece lógico e nem econômico do ponto de vista processual, pelo menos nos casos em que exista de fato uma produção de provas, a necessidade de se passar pelo crivo de outro magistrado os documentos, os depoimentos e as demais provas já apreciadas enquanto elementos de convicção do juiz do trabalho. Principalmente, após a inserção de norma jurídica constitucional que atribui a esse mesmo magistrado o dever de executar de ofício as contribuições devidas à seguridade social decorrentes das sentenças que proferir.

É certo que o servidor público, adstrito aos limites estabelecidos pelos princípios que norteiam a Administração Pública, em especial o da legalidade, deve observar o comando normativo quando da inserção de dados nos cadastros mantidos pela previdência. Dentre os cuidados inerentes à função estaria, conforme lição de Hermes Arrais Alencar ${ }^{145}$, a observância da pré-existência de documentos contemporâneos ao fato que se colima comprovar para fins de obtenção de benefício.

Acontece que, quando estamos falando de uma sentença trabalhista, essa observância da legalidade enquanto princípio deve tomar outro foco, afinal não é possível admitir que no comando inserido no texto infraconstitucional esteja prevista uma autorização para que o INSS ignore a norma jurídica individual e concreta produzida por um órgão Poder Judiciário, legítimo Poder da República, obedecidos os comandos processuais constitucionais. Isso não nos parece republicano.

145 "Para a inserção de tempo de trabalho nos cadastros da previdência social, para efeito de obtenção de benefício previdenciário, exige-se a apresentação de documento contemporâneo ao fato que se colima comprovar, denominado início de prova material." (ALENCAR, Hermes Arrais. Benefícios Previdenciários. $4^{a}$ ed. São Paulo: LEUD, 2011, p. 430.) 
Conforme já abordamos em tópico antecedente, o reconhecimento de um fato jurídico trabalhista produz efeitos em vários ramos do direito (trabalhista, fiscal, administrativo, previdenciário, etc.). Assim, com a formalização de um vínculo ou a retificação deste como consequência de uma intervenção judicial, deveríamos garantir ao trabalhador a proteção, também, do ponto de vista previdenciário, principalmente após a inserção de comando constitucional que garante a proteção do fisco quanto à arrecadação das contribuições sociais decorrentes da sentença trabalhista.

Nesse contexto, os efeitos previdenciários devem surgir automaticamente em decorrência da sentença trabalhista, sem que a autarquia previdenciária possa exigir qualquer outra comprovação para reconhecer o teor daquele documento para fins de inserção ou correção de dados no Cadastro Nacional de Informações Sociais do trabalhador, em especial quanto a sua qualidade de segurado, a carência, o salário de contribuição e o tempo de contribuição.

A sentença trabalhista que declara um vínculo de emprego ou retifica-o, com o trânsito em julgado e seus efeitos, deveria gozar de eficácia plena para produzir os efeitos em âmbito previdenciário, seja enquanto vinculação automática ou como consequência da reciprocidade contributiva.

Cumpre-se destacar que as sentenças declaratórias produzem efeito ex tunc, ou seja, retroagem no tempo para alcançar a data dos fatos que se pretendam confirmar em juízo. É exatamente em razão desse efeito que a sentença trabalhista que declara um direito (e.g. reconhecimento de vínculo) tem a eficácia necessária para determinar incidência retroativa da norma.

Via de regra, na Justiça do Trabalho, as sentenças têm natureza mista, em um primeiro momento declaram um direito e, depois, condenam a parte sucumbente em uma série de obrigações decorrentes do reconhecimento desse fato pretérito, por exemplo, a determinação de anotação de CTPS do empregado.

A discussão doutrinária e jurisprudencial que permeia o tema dos efeitos previdenciários da sentença trabalhista gira em torno do fato de que os elementos capazes de formar a convicção do magistrado trabalhista podem se revestir das mais variadas formas.

A mesma sentença que reconhece um vínculo de emprego, por exemplo, pode embasar-se em farta prova documental, a qual, ratificada por testemunhas, como, também, pode ser fruto da homologação de um acordo na fase inicial da 
audiência, sem que qualquer prova tenha sido necessariamente produzida. Há, ainda, sentenças que se baseiam exclusivamente na prova testemunhal, perante o princípio da oralidade inerente ao sistema do direito do trabalho.

Igualmente, pode haver a declaração de um direito enquanto decorrência de uma confissão ficta, fruto da revelia da parte contra quem se pretenda provar um fato jurídico. Seja como for, o fato é que a sentença, uma vez transitada em julgada, passará a produzir seus efeitos no mundo jurídico, diante da incidência normativa por meio de instrumento introdutor legítimo.

O artigo 456 da Consolidação das Leis do Trabalho prescreve que a prova do contrato individual do trabalho é feita pelas anotações constantes da Carteira de Trabalho e Previdência Social ou por instrumento escrito e suprida por todos os meios permitidos em direito. Por sua vez, o inciso I do artigo 40 do mesmo diploma legal revela a importância das anotações em carteira para fins de comprovação de tempo de serviço perante a previdência social.

Ora, se as anotações em CTPS podem ser supridas por qualquer meio de prova em direito admitido, bem como que essas informações prevalecem enquanto comprovação de tempo de serviço, o INSS, ao rejeitar a sentença trabalhista enquanto meio de prova para fins de inserção ou retificação de dados no Cadastro Nacional de Informações Sociais afronta a previsão normativa prevista nos dispositivos suprarreferidos.

Ademais, o próprio Código de Processo Civil, de aplicação subsidiária ao processo do trabalho ${ }^{146}$, em seu artigo 332 , traz a previsão de que os fatos podem ser provados por qualquer meio de prova, desde que legais e moralmente aceitáveis. A Constituição também prestigia a comprovação dos fatos por meios lícitos $^{147}$, e ao estabelecer nos direitos e garantias fundamentais a inadmissibilidade da prova ilícita, em interpretação reversa, prevê a possibilidade de se fazer prova por qualquer meio, desde que legal.

Nessa seara, fazendo uma interpretação sistemática das normas jurídicas que regem as relações trabalhistas, o custeio da previdência e a concessão de benefícios, podemos estabelecer que, em razão do efeito ex tunc da sentença que declara direitos trabalhistas, pelo menos, em tese, estaria suprida a

\footnotetext{
146“'Art. 769 - Nos casos omissos, o direito processual comum será fonte subsidiária do direito processual do trabalho, exceto naquilo em que for incompatível com as normas deste Título."

147 "Art. $5^{\circ}($...) LVI - são inadmissíveis, no processo, as provas obtidas por meios ilícitos;"
} 
necessidade de produção de prova material supletiva em ambiente administrativo ou judicial, nos termos do parágrafo $3^{\circ}$ do artigo 55 da Lei ํㅡㄹ.213/91.

Diante do entendimento acima exposto, impossível concordar que poderia ser exigível a produção de prova material para que a sentença trabalhista já transitada em julgado possa produzir seus efeitos no tocante à incidência normativa previdenciária. Defender essa exigibilidade vai de encontro com a ordem republicana e a separação dos poderes impostas por nossa Constituição, causando insegurança jurídica, na medida em que um fato pode receber tratamento diferenciado pelos poderes da República.

Dessa feita, não atribuir plena eficácia à sentença trabalhista, inclusive para fins de reconhecimento de carência, tempo de contribuição e salário de contribuição, é o mesmo que transformar a Justiça do Trabalho em um mero instrumento de arrecadação em favor do fisco.

Portanto, se houve uma decisão da qual decorreu o dever de recolhimento da contribuição social, ressalvadas as hipóteses de prescrição e decadência, deve emergir automaticamente o dever de o Estado cumprir a ordem constitucional de cobertura dos eventos que demandem a sua intervenção por meio da previdência.

Em outras palavras, mesmo diante das já exaustivamente apontadas falhas dogmáticas na execução do crédito tributário na Justiça do Trabalho, para que seja garantida a total eficácia prática da norma jurídica inserida no dispositivo constitucional, imperativa se faz a interpretação de que também estaria inserida, de forma oculta, no mesmo artigo a atribuição de competência para que o magistrado trabalhista, após a comprovação dos recolhimentos fiscais, determine a inserção dos dados decorrentes dos julgados proferidos no Cadastro Nacional de Informações Sociais (CNIS), vinculado ao obreiro que teve reconhecido os seus direitos. 


\section{CONCLUSÃO}

Diante de tudo o que foi exposto no presente trabalho, algumas são as conclusões lógicas possíveis de serem atingidas. A primeira delas é que para haver a validade de um mecanismo de introdução de norma em um sistema, é fundamental a sua compatibilidade com as demais regras e princípios norteadores de sua formalização procedimental.

A fenomenologia da incidência normativa, conforme vimos, passa pela declaração de um fato social por meio de procedimento estabelecido no ordenamento jurídico e através de instrumento introdutor de norma compatível com a sua sistemática. A linguagem utilizada no processo de subsunção deve ser àquela estabelecida previamente em norma geral de regência.

Uma vez definida a natureza jurídica tributária da contribuição social, algumas consequências jurídicas são obrigatórias, em especial no tocante à forma como se deve dar originalmente a constituição desse crédito.

Por se tratar de tributo que obedece a sistemática de lançamento por homologação, nos termos do artigo 150 do CTN e do parágrafo $7^{\circ}$ do artigo 33 da Lei $n^{\circ} 8.212 / 91$, é por meio da GFIP que o contribuinte declara os fatos jurídicos suscetíveis de incidência do tributo e formaliza o seu recolhimento. A GFIP é, portanto, o instrumento introdutor da norma jurídica fiscal-previdenciária no sistema tributário.

Em caso de descumprimento pelo contribuinte é a Administração Pública, em razão do seu poder-dever de fiscalização que deve promover de ofício o lançamento dentro do período decadencial para esse fim, bem como, persistindo a inadimplência, inscrever o crédito na Dívida Ativa para que seja possível a sua execução na Justiça Federal antes que seja corroído pela prescrição. Desta feita, importantíssima a fixação do fato gerador de incidência tributária para fins de controle desses prazos fixados no CTN em cinco anos para constituir e executar a contribuição social decorrente do trabalho.

Como o dispositivo constitucional objeto do presente estudo trata apenas das contribuições devidas pelo empregado e empregador em razão da prestação de serviço com vínculo empregatício e incidente sobre o salário e folha de pagamento, respectivamente, compete-nos fixar esse marco temporal apenas nestas duas hipóteses, as quais se consumam, simultaneamente, quando da a prestação de serviço remunerado. 
O artigo 52 da Instrução Normativa da Receita Federal n 971/09 dispõe que a ocorrência do fato gerador se dá quando for paga, devida ou creditada a remuneração, o que ocorrer primeiro. Assim, transcorridos cinco anos, contados a partir da competência subsequente à data em que o lançamento deveria ter ocorrido, extingue-se o direito da União constituir o seu crédito ${ }^{148}$. Se constituído o crédito dentro do quinquênio legal, prescreve em cinco anos o direito de exigi-lo judicialmente por meio de execução fiscal.

O inciso VIII do artigo 114 da Constituição, no entanto, acabou inserido no ordenamento jurídico a possiblidade de execução incidental ao processo do trabalho das contribuições sociais decorrentes dos julgados proferidos naquela justiça especializada.

Como os fatos jurídicos suscetíveis de incidência tributária podem ser declarados por meio de sentença trabalhista, poderia se gerar alguma dúvida em relação ao fato gerador da contribuição social decorrente dela. Porém, da investigação da base-de-cálculo, verificamos que a contribuição decorre da obrigação de pagar, e não do efetivo pagamento do salário. Em outras palavras, ainda que a verba salarial sujeita à incidência de tributo somente venha a ser paga por ocasião da execução da obrigação trabalhista, nasceu à época do exercício da atividade laboral o dever de recolher a exação fiscal.

Inclusive, essa é a disposição prevista no parágrafo $2^{\circ}$ do artigo 43 da Lei $n^{\circ}$ 8.212/91, que atribui ao momento da prestação do serviço a ocasião da ocorrência do fato imponível tributário da contribuição destinada ao custeio da Seguridade Social.

Cumpre-se destacar que a norma processual aplicável na execução ex officio da contribuição social na Justiça do Trabalho é àquela inserida na CLT por força da Lei $n^{\circ} 10.035 / 00$. Entretanto, até a presente data, não foi inserido no Sistema Jurídico Trabalhista norma material específica relativa a constituição desse crédito fiscal, o que nos leva a crer que deve prevalecer o ordenamento jurídico vigente, prioritariamente o CTN e a Lei n8.212/91.

Neste diapasão, a sentença trabalhista padece de similitude enquanto instrumento introdutor de norma tributária, na medida em que o processo de constituição da norma trabalhista é regido por princípios próprios e incompatíveis

148 Art. 173, inciso I do CTN. 
com o direito tributário. Ela não pode ser equiparada ao lançamento, primeiro por que se tratar de ato administrativo vinculado, depois, porque não goza de linguagem competente para declarar a existência de um fato jurídico tributário e, muito menos para constituir o crédito.

Em que pese a norma constitucional não haver feito tal limitação, o parágrafo único do artigo 876 da CLT prevê expressamente a acessoriedade da execução fiscal às sentenças trabalhistas condenatórias e às homologatórias de acordo, excluindo dessa modalidade as sentenças meramente declaratórias, mesmo sendo exatamente esse cunho declaratório de fatos jurídicos geradores de tributo que dão parcial consistência à execução em sede trabalhista.

Os fundamentos de incidência normativa abordados no presente estudo nos conduzem a conclusão de que sob um mesmo fato social podem incidir várias regras jurídicas decorrentes dos mais variados sistemas, as denominadas normas gerais e abstratas de conduta.

Contudo, para que essas normas incidam efetivamente, é fundamental uma ação humana, por sujeito competente, que atribua linguagem ao tal fato social por meio de instrumento próprio, juridicizando-o, para que só então passe a ter relevância necessária para que dele decorram os efeitos previstos no consequente da norma geral.

Desse processo de subsunção resultará uma nova norma jurídica, individual e concreta, a qual deve ter em seu antecedente a descrição da conduta suscetível de incidência da norma geral e no consequente os efeitos que dela se espera.

Assim, para que o fato ganhe os contornos jurídicos inerentes à ele é preciso que, em primeiro plano, a conduta esteja prevista no antecedente de uma norma geral e abstrata, enquanto obrigação de ser, bem como que haja no consequente dessa mesma norma a previsão de uma sanção pelo descumprimento dessa regra de conduta, pelo não ser, ou uma implicação prática pelo próprio ser, como no caso do Direito Tributário.

Existe, portanto, no antecedente dos artigos 20 e 22, inciso I da Lei 8.212/91 a previsão de contribuição para o empregado e empregador incidente sobre a remuneração e folha de pagamento respectivamente, sendo que no consequente desses mesmos dispositivos está prevista a alíquota de incidência em razão da conduta (ser empregado ou empregador). 
Ocorre que, o simples fato de ser empregador ou empregado não é suficiente para que essa norma jurídica geral e abstrata produza seus efeitos, é necessário, igualmente, que outra norma jurídica traga a previsão da forma e do sujeito competente para fazer incidir o consequente normativo, no caso da contribuição social, o próprio contribuinte, que declara o fato gerador e constitui o crédito sujeito a homologação da Receita Federal. $O$ instrumento introdutor da norma individual e concreta para esse tipo de tributo é a GFIP, nos termos da Lei $n^{\circ} 11.941 / 09$ e Instrução Normativa da Receita Federal n`971/09.

É o contribuinte, destarte, que ao verter em linguagem o fato social através do preenchimento dos formulários da GFIP, que produz uma norma jurídica individual e concreta para fins de arrecadação da verba destinada ao custeio da Seguridade Social, a qual pode ou não ser homologada pelo fisco dentro do prazo decadencial. Esse é o procedimento previsto no Sistema Jurídico Tributário, ao qual pertence a contribuição social em razão de sua natureza.

As alterações na CLT em decorrência da Lei $n^{\circ} 10.035 / 00$ trouxeram para o antecedente da norma jurídica processual trabalhista a previsão de que na hipótese de condenação ou homologação de acordo, existe como consequência a exigibilidade por meio da execução de ofício do tributo decorrente do mesmo fato declarado por sentença proferida na Justiça do Trabalho.

A sentença trabalhista é, portanto, instrumento introdutor de norma jurídica individual e concreta por meio do qual o juiz, sujeito competente, verte em linguagem o fato social, declarando em seu antecedente a existência ou não do mesmo para os fins jurídicos e no consequente (dispositivo) atribui ao sujeito passivo uma obrigação de natureza trabalhista.

O ordenamento processual aplicável ao processo trabalhista prevê a necessidade de respeito aos limites estabelecidos pelas partes para fins declaratórios e condenatórios, sendo certo que à outorga de competência para execução ex officio, de alguma forma, possibilita a cobrança forçada da exação fiscal previdenciária fora dos limites do pedido.

Por essa ótica, a contribuição social decorrente de uma sentença trabalhista mais parece uma consequência lógica do fato jurídico trabalhista do que uma construção normativa capaz de ser executada pela justiça do trabalho. Podemos, inclusive, invocar a teoria de Liebman, que entende que a sentença, 
enquanto ato de Estado, possui uma eficácia natural perante terceiros, no caso a Receita Federal.

Há, no entanto, uma limitação infraconstitucional à competência atribuída constitucionalmente à Justiça do Trabalho para executar as contribuições sociais, qual seja, a preexistência de possibilidade de execução de crédito trabalhista, mais especificamente, uma sentença condenatória ou homologatória de acordo.

Acontece que mesmos as sentenças condenatórias possuem dupla função, na medida em que num primeiro momento declaram a existência de um fato jurídico previsto no antecedente de uma norma geral e abstrata e, após, deixa evidente o seu conteúdo condenatório, decorrente da aplicação das sanções previstas no consequente dessa mesma norma geral e abstrata, a penalização pelo não cumprimento do dever ser ou os efeitos jurídicos decorrentes do ser.

Por conseguinte, um mesmo evento do mundo fenomênico pode ser capaz de desencadear uma série de relações jurídicas, entretanto a exigibilidade só pode ser verificada após a aplicação da norma decorrente de cada ramo do direito, através de linguagem e sujeito competentes e procedimento próprio de subsunção.

Nessa mesma linha, ainda que na parte declaratória da sentença trabalhista condenatória ou homologatória de acordo seja reconhecido um fato suscetível de incidência da contribuição social, inexiste na parte dispositiva a constituição de um título executivo tributário, a execução de ofício não guarda suporte em justo título judicial ou extrajudicial.

A quantificação do valor do tributo, ou seja, a fixação da base de cálculo é providenciada pelo próprio magistrado trabalhista de maneira indireta, seja na parte dispositiva da sentença condenatória líquida, na discriminação das verbas no acordo homologado ou no procedimento de liquidação de sentença, o qual precede as execuções trabalhistas nos caso de decisão ilíquida.

É certo que o sujeito passivo da obrigação tributária decorrente da prestação de serviço participa de toda a fase de constituição do crédito trabalhista, podendo, inclusive, discutir os cálculos do valor atribuído para fins fiscais na liquidação ou na fase de execução em caso de discordância. Contudo, inexiste momento correspondente à constituição do crédito tributário em ambiente trabalhista. 
Não se pode verificar a incidência normativa tributária por meio de sentença trabalhista, pois a mesma não pode ser equipara ao lançamento, bem como a execução padece de respaldo em título executivo, na medida em que a formalização do mesmo também depende de um ato administrativo, denominado inscrição na Dívida Ativa.

Em que pese o acima exposto, o procedimento, no caso de descumprimento pelo contribuinte do dever de recolher o tributo decorrente de fatos reconhecidos por sentença, é efetivamente de execução, posto que pode culminar, inclusive, com a constrição de bens para que seja satisfeita a obrigação fiscal, sempre em acessoriedade à trabalhista.

A falha dogmática reside no fato de que para ser possível a admissão do processo de execução de ofício das contribuições previdenciárias, é imprescindível se admitir a constituição prévia do título executivo fiscal, enquanto decorrência lógica da decisão proferida após o encerramento da fase de conhecimento ou do acordo entre as partes do processo devidamente homologado.

Para a União, no entanto, a sentença não pode ser considerada título executivo, judicial ou extrajudicial, na medida em que a mesma não é parte no processo na fase de conhecimento.

A sentença não se equipara à condição de fato gerador ou de lançamento tributário. $O$ fato gerador é apenas declarado no antecedente normativo da norma individual e concreta inserida no sistema jurídico trabalhista por meio de sentença, posto que se confunde, por sua própria natureza, com o fato pretérito cuja ocorrência está prevista no ordenamento tributário e que, também, dá ensejo à condenação trabalhista.

Somente seria possível se admitir a incidência normativa fiscal no curso de processo trabalhista, se entendêssemos que estaria inserido na norma constitucional a certeza de que a incidência da norma previdenciária é automática e concorrente à da norma trabalhista, independentemente de qualquer atividade humana para fins de constituição do crédito.

Em outras palavras, a sistemática de execução de ofício nos remete a conclusão de que a contribuição social decorrente dos julgados trabalhista se constitui automática e infalivelmente, em que pese não ser formalizado um título 
executivo fiscal por meio desse instrumento introdutor de norma individual e concreta de natureza laboral.

Portanto, o procedimento criado pelo inciso VIII do artigo 114 da Constituição e regulado pelas alterações previstas na Lei $n^{\circ} 10.035 / 00$ parece guardar muito mais relação com a hipótese de arrecadação na fonte de receita, em razão do reconhecimento de fatos jurídicos tributáveis, a qual deve ser fiscalizada pelo magistrado trabalhista, do que propriamente com procedimento de execução de tributo.

Em que pese ter dado cumprimento ao princípio tributário da praticidade, pois fortalece a arrecadação das contribuições sociais quando decorrentes de sentenças trabalhistas, do ponto de vista da ciência do direito, principalmente quanto à introdução de norma jurídica tributária individual e concreta válida no sistema do direito positivo por um instrumento introdutor de norma sui generis, pairam algumas questões que permanecem impossíveis de serem validadas.

Outrossim, ainda que se admitisse a possibilidade de constituição do crédito tributário através de sentença trabalhista, partindo da premissa de que, em havendo norma geral de estrutura que determina a execução do referido tributo de oficio pelo magistrado trabalhista, estaria inserido no seu conteúdo a norma geral e abstrata de incidência de norma tributária, mesmo assim, essa relação jurídica não estaria fechada dogmaticamente, pois a Justiça do Trabalho não goza da mesma autonomia para fazer incidir as consequências jurídicas do recolhimento da contribuição.

O tributo por sua natureza deve retornar ao contribuinte na forma de serviços ou benefícios, trata-se da reciprocidade contributiva, que deve ser inerente, também, à contribuição social.

Nesse contexto, além de se tratar de uma norma introduzida por instrumento frágil, a contribuição social decorrente de sentença trabalhista padece de requisito essencial de sua existência, a capacidade de produzir seus efeitos de retribuição ao cidadão.

Os princípios norteadores da Seguridade Social nos mostra que os pilares desse sistema apoiam-se fundamentalmente no fortalecimento do custeio e na garantia de cobertura mais abrangente possível.

A alteração constitucional que atribuiu à Justiça do Trabalho o dever de executar por impulso oficial as contribuições sociais decorrentes de seus julgados 
contribuiu para o atingimento de uma parcela dessa estrutura, a arrecadação, mas deixou a desejar na questão de garantia de ampla cobertura previdenciária, posto que o dispositivo constitucional não atribuiu ao magistrado a mesma autonomia para conferir efeitos previdenciários aos seus julgados.

Assim, fazendo uma lógica inversa ao princípio de manutenção do equilíbrio financeiro e atuarial do sistema securitário, a reciprocidade na previdência social decorre do fato de que uma vez realizada a contribuição sobre parcela da remuneração do cidadão, obrigatório o seu computo para fins de apuração de tempo de serviço e valor do salário de benefício.

Conforme visto em capítulo anterior, a principal fonte de informações do CNIS é a GFIP, sendo que, nos termos do artigo 32 da Lei no 8.212/91, as empresas estão obrigadas a informar todos os dados referentes aos trabalhadores a elas vinculados, em especial sobre tempo de serviço e remuneração paga.

Em decorrência dessa obrigação de informação decorrente do Sistema da Seguridade Social, com o reconhecimento de vínculo empregatício por sentença trabalhista e a determinação do respectivo recolhimento da contribuição social, passa a existir, necessariamente, a vinculação previdenciária do decisum. Podemos presumir, então, que é por isso que a Instrução Normativa do INSS no 95/03 exige que os seus procuradores se manifestem nas ações trabalhistas que vierem a ter reflexos no direito previdenciário.

Talvez, o ideal fosse que a União, representada pela autarquiaprevidenciária, participasse como litisconsorte ativo necessário ou terceiro interessado desde a fase de conhecimento da lide trabalhista, de forma que a sentença trabalhista pudesse gozar de maior eficácia para fins previdenciários. Entretanto, a União participa da lide apenas quando da fase de execução da contribuição social, sendo-lhe facultada a discussão do quantum debeatur fiscalprevidenciário decorrente da decisão transitada em julgado.

Destaca-se nesse ponto que, qualquer que seja o critério de valoração qualitativa da sentença trabalhista enquanto meio de prova perante o INSS para fins de averbação de tempo de serviço e salários de contribuição, o vínculo reconhecido por sentença trabalhista se dá na presença e pela intervenção de um juiz togado, investido de jurisdição, vinculado ao ordenamento jurídico e a todas as formalidades do processo judicial. 
Consequentemente, em respeito à reciprocidade contributiva, se 0 magistrado trabalhista arrecada em favor do fisco previdenciário, se o INSS não apresenta impugnação ao valor recolhido, se há no processo o reconhecimento de vínculo ou de qualquer outro fato que deva alterar a situação cadastral do reclamante na previdência, imperativa a atribuição de eficácia previdenciária à sentença trabalhista e a outorga de competência ao magistrado do trabalho para, também de ofício, determinar a averbação do tempo, do salário ou da especialidade da profissão no Cadastro Nacional de Informações Sociais.

É possível, destarte, suscitar a inconstitucionalidade do artigo 55 da Lei no 8.213/91, pois condicionar a eficácia da sentença trabalhista transitada em julgado à produção de outras provas do fato trabalhista devidamente constituído se mostra um contrassenso ao princípio da economia processual, aos fundamentos de validade da norma jurídica trabalhista individual e concreta, ao comando constitucional arrecadatório atribuído ao magistrado trabalhista e ao princípio da reciprocidade contributiva, por consequência.

A argumentação do INSS de um suposto desprestígio da prova produzida na Justiça do Trabalho para deixar de reconhecer os efeitos previdenciários do vínculo trabalhista reconhecido por sentença afronta a efetividade da tutela jurisdicional, uma vez que, como já tratado, na teoria de Liebman, um mesmo fato não poderia receber tratamento diverso por autoridade administrativa, a qual, supostamente, estaria adstrita ao entendimento emanado judicialmente.

É da Justiça do Trabalho a competência privativa para declarar a existência ou inexistência de vínculo empregatício ou de outros fatos de natureza trabalhista, por força da Emenda Constitucional $n^{\circ}$ 45/04. O princípio da legalidade determina que o INSS não ignore a norma jurídica individual e concreta produzida por um órgão Poder Judiciário, legítimo Poder da República, desde que obedecidos os comandos processuais constitucionais.

Os efeitos previdenciários, portanto, devem surgir automaticamente em decorrência da sentença trabalhista, sem que a autarquia previdenciária possa exigir qualquer outra comprovação para reconhecer o teor daquele documento para fins de inserção ou correção de dados no CNIS do trabalhador, seja enquanto vinculação automática ou como consequência da reciprocidade contributiva. 
Fazendo uma interpretação sistemática das normas jurídicas que regem as relações trabalhistas, o custeio da previdência e a concessão de benefícios, podemos estabelecer que, em razão do efeito ex tunc da sentença que declara direitos trabalhistas, pelo menos, em tese, estaria suprida a necessidade de produção de prova material supletiva em ambiente administrativo ou judicial, nos termos do parágrafo 3ำ do artigo 55 da Lei nำ 8.213/91.

Não atribuir plena eficácia previdenciária à sentença trabalhista, inclusive para fins de reconhecimento de carência, tempo de contribuição e salário de contribuição, é o mesmo que transformar a Justiça do Trabalho em um mero instrumento de arrecadação em favor do fisco.

Em razão de todo os exposto, ou se atribui à sentença trabalhista efeito apenas probatório para fins de constituição do crédito tributário, inclusive enquanto marco interruptivo ou suspensivo de contagem dos prazos de extinção do crédito tributário, tratando-o em ambiente trabalhista como mera fiscalização da arrecadação na fonte de competência do sujeito passivo da obrigação tributária ou, para que seja garantida a total eficácia prática da norma jurídica inserida no dispositivo constitucional, imperativa a interpretação de que também estaria inserida, de forma oculta, no mesmo artigo a atribuição de competência para que o magistrado trabalhista, após a comprovação dos recolhimentos fiscais, determine a inserção dos dados decorrentes dos julgados proferidos no Cadastro Nacional de Informações Sociais - CNIS vinculado ao obreiro que teve reconhecido os seus direitos. 


\section{BIBLIOGRAFIA}

ALEMÃO, Ivan. Cobrança do crédito do INSS: Lei no $10.035 / 2000$. Revista LTr, São Paulo, no 65-04/435, abr. 2001.

ALENCAR, Hermes Arrais. Benefícios Previdenciários. 4a ed. São Paulo: LEUD, 2011. AMARO, Luciano. Direito tributário brasileiro. 17ª ed. atual. São Paulo: Saraiva, 2011. . Direito Tributário Brasileiro. 12ª ed. rev. e atual. São Paulo: Saraiva, 2006. Direito tributário Brasileiro. 10ª ed. Atual. São Paulo: Saraiva, 2004.

AVILA, Alexandre Rossato da Silva. Curso de direito tributário. 6 a $^{\text {a }}$ ed. Porto Alegre: Verbo Jurídico, 2011.

BALERA, Wagner. Noções Preliminares de Direito Previdenciário. São Paulo: Quartier Latin, 2004.

BARROS, Alice Monteiro de. Curso do direito do trabalho. $7^{a}$ ed. São Paulo: LTr, 2011. BOBBIO, Norberto. Teoria do ordenamento jurídico. $8^{\underline{a}}$ ed. Brasília: Universidade de Brasília, 1996.

BORGES, José Souto Maior. Lançamento Tributário. Rio de Janeiro: Forense, 1999. BUENO, Cassio Scarpinella. O poder pública em juízo. São Paulo: Saraiva, 2005. CANOTILHO, José Joaquim Gomes. Direito constitucional. Coimbra: Almedina, 1992. CARVAlHO, Aurora Tomazini de. Curso de Teoria Geral do Direito (o Constructivismo Lógico-Semântico). São Paulo: Noeses, 2010.

CARVALHO, Paulo de Barros. "A Prova no Procedimento Administrativo Tributário". In: Revista Dialética de Direito Tributário. São Paulo: Dialética, 1998, 34: 104-116. Curso de Direito Tributário. 13a ed. São Paulo: Saraiva, 2005.

"O preâmbulo e a prescritividade constitutiva dos textos jurídicos". In: Derivação e Positivação no Direito Tributário. Vol. I. São Paulo: Noeses, 2012. . Curso de direito tributário. São Paulo: Saraiva, 2011.

. Direito Tributário, Linguagem e Método. São Paulo: Noeses, 2011.

Direito Tributário: fundamentos jurídicos da incidência. 9ª ed., São Paulo: Saraiva, 2011.

Direito tributário: fundamentos jurídicos da incidência. São Paulo: Saraiva, 2011: Palavras introdutórias e Preâmbulo.

Curso de Direito Tributário. 25a ed., São Paulo: Saraiva, 2013.

A Ciência Do Direito e o Direito Positivo: Texto inédito.

CASTILHO, Paulo Cesar Bária de. Execução de Contribuição Previdenciária pela justiça do trabalho. São Paulo: Editora Revista dos Tribunais, 2005.

CASTRO, Carlos Alberto Pereira de; LAZZARI, João Batista. Contribuição à seguridade social em razão das decisões proferidas pela Justiça do Trabalho e sua execução. Revista LTr, São Paulo, no 63-02/178, fev. 1999. 
Manual de Direito Previdenciário. 5ª ed., São Paulo: LTr, 2004.

Manual de direito previdenciário. 13 $3^{\mathrm{a}}$ ed. São Paulo: Conceito Editorial, 2011.

CHIOVENDA, Giuseppe. Instituições de Direito Processual Civil. Tradução Paolo Capitanio. Campinas: Bookseller, 1998.

CORREIA, Marcus Orione Gonçalves. "Das inconsistências jurídicas da competência atribuída à Justiça do Trabalho para a execução de ofício de contribuições sociais decorrentes de suas sentenças”. Revista LTr, São Paulo, oํ 65-04/422, abr. 2001.

Curso de Direito da Seguridade Social. $2^{2}$ ed. São Paulo: Saraiva, 2002.

DALAZEN, João Oreste. Competência material da justiça do trabalho. São Paulo: LTr, 1994.

DELGADO, Maurício Godinho. Curso de Direito do Trabalho. 6 $6^{\underline{a}}$ ed. São Paulo: LTR, 2007.

DE MIRANDA, Francisco Cavalcante. Tratado de Direito Privado, tomo I. Atualizado por Vilson Rodrigues Alves. $1^{\mathrm{a}}$ ed. Campinas: Bookseller, 1999.

DIAS, Eduardo Rocha e MACÊDO, José Leandro Monteiro de. Curso de Direito Previdenciário. $1^{\underline{a}}$ ed. São Paulo: Método, 2008.

DINAMARCO, Cândido Rangel. Instituições de Direito Processual Civil. V. I. 4ª ed. São Paulo: Malheiros, 2004.

DINIZ, Maria Helena. Norma constitucional e seus efeitos. São Paulo: Saraiva, 1989.

DI PIETRO, Maria Sylvia Zanella. Direito administrativo. 24를 ed. São Paulo: Atlas, 2011.

ENESES, Geraldo Magela e Silva. "Competência da Justiça do Trabalho Ampliada em Face da EC n. 20/98". In Revista LTr. São Paulo, v. 63, n. 2, fev., 1999.

FELICIANO, Guilherme Guimarães. Execução de Contribuições Sociais na Justiça do Trabalho. São Paulo: LTr, 2002.

FERRAZ JÚNIOR, Tércio Sampaio. Antinomia. Enciclopédia Saraiva de Direito. São Paulo: Saraiva, 1978. v. 7, p. 9.

Introdução ao Estudo do Direito: Técnica, Decisão, Denominação. $7^{a}$ ed. São Paulo: Atlas, 2013.

FRACARO, Vandir. O efeito da sentença trabalhista no direito previdenciário. Disponível em http://www.administradores.com.br/informe-se/artigos/o-efeito-dasentenca-trabalhista-no-direito-pevidenciario/34761/, acesso em 17/10/2011.

FRANÇA, Vladimir da Rocha. "Eficiência administrativa". In: Revista de Direito Administrativo. Rio de Janeiro: Renovar, n. 220, abr./jul. 2000.

GARCIA, Gustavo Filipe Barbosa. "A nova redação da súmula n. 368 do TST e as contribuições previdenciárias referentes ao vínculo de emprego reconhecido pela justiça do trabalho". In: Revista LTr. São Paulo: LTr. Ano 70. n. 1, janeiro de 2006. 
IBRAHIM, Fábio Zambitte. Curso de direito previdenciário. 16 ${ }^{\underline{a}}$ ed. Rio de Janeiro: Impetus, 2011.

GONÇALVES, Odonel Urbano. Seguridade Social Comentada. São Paulo, LTr., 1997. HARADA, Kiyoshi. Direito Financeiro e Tributário. 10ª ed. São Paulo: Atlas, 2010. IBRAHIM, Fábio Zambitte. Curso de Direito Previdenciário. 16 ed. rev., ampl. e atual. Rio de Janeiro: Impetus, 2011.

JARDIM, Eduardo Marcial Ferreira (coord.); PASIN, João Bosco Coelho (coord.). Tributos em espécie: fundamento e elementos. Rio de Janeiro: Elsevier, 2010. JORGE NETO, Francisco Ferreira; CAVALCANTE, Jouberto de Quadros Pessoa. Curso do direito do trabalho. $2^{\mathrm{a}}$ ed. - São Paulo: Atlas, 2011.

JUSTEN FILHO, Marçal. Curso de direito administrativo. $7^{\text {a }}$ ed. rev. e atual. Belo Horizonte: Fórum, 2011.

KELSEN, Hans. Teoria Pura do Direito. Tradução João Baptista Machado. $8^{a}$ ed. São Paulo: Editora Martins Fontes, 2009.

LAGE, Emerson José Alves; LOPES, Mônica Sette (coord.). Execução previdenciária aspectos jurisprudenciais e doutrinários. Belo Horizonte: Del Rey, 2003.

LEITE, Carlos Henrique Bezerra. Curso de direito processual do trabalho. 9a ed. São Paulo: LTr, 2011.

LIEBMAN, Enrico Tullio. Eficácia e Autoridade da Sentença. Rio de Janeiro: Forense, 1945.

Processo de Execução. 3ª ed., São Paulo: Saraiva, 1968.

LUCON, Paulo Henrique dos Santos. Devido Processo Legal Substancial. Artigo escrito para a Academia Brasileira de Direito Processual Civil - ABDPC, visualizado em 14/12/2014. (www.abdpc.org.br/artigos/artigo1015.doc)

MACHADO JR., César P. S. "A execução das contribuições previdenciárias". Revista de Previdência Social. São Paulo: LTr, no 244, p. 160, mar. 2001.

MARQUES, José Frederico. Manual de Direito Processual Civil. $3^{\underline{a}}$ ed., São Paulo: Saraiva, 1975.

MARTINEZ, Luciano. Curso do direito do trabalho: relações individuais, sindicais e coletivas do trabalho. $2^{\underline{a}}$ ed. São Paulo: Saraiva, 2011.

MARTINEZ, Wladimir Novaes. A Seguridade Social na Constituição Federal. $2^{\underline{a}}$ ed. São Paulo: LTR, 1992.

Comentários à lei básica da previdência social. São Paulo: LTr, 1996. t. 1. Comentários à Lei Básica da Previdência Social. $2^{-a}$ ed. São Paulo: LTr, 1996.

Curso de direito previdenciário. 4를 ed. São Paulo: LTr, 2011. 
MARTINS, Ives Gandra da Silva (coord.). Curso de direito tributário. 13 ${ }^{\underline{a}}$ ed. São Paulo: Saraiva, 2011.

MARTINS, Sérgio Pinto. Execução da contribuição previdenciária no processo do trabalho. Repertório IOB de jurisprudência, no 23/2000, texto 2/16745, p. 461, dez. 2000.

Comentários à CLT. 10ª ed. São Paulo: Atlas, 2006.

Direito da seguridade social. 24⿳亠丷⿵冂⿱ ed. São Paulo: Atlas, 2007.

Execução da Contribuição Previdenciária na Justiça do Trabalho. 3ª ed.

São Paulo: Atlas, 2008.

Comentários à CLT. 10ª ed. São Paulo: Atlas, 2013.

Comentários à CLT. 17ª ed. São Paulo: Atlas, 2013.

Direito da Seguridade Social. 33ª ed. São Paulo: Atlas, 2013.

. Direito Processual do Trabalho. 34를 ed. São Paulo: Atlas, 2013.

MÉLEGA, Luiz. Algumas Reflexões Sobre o Regime Jurídico das Contribuições na

Carta Política de 1988. Direito tributário atual. São Paulo: Resenha Tributária, $\mathrm{n}^{\circ}$ $11 / 12$.

MENESES, Geraldo Magela e Silva. "Competência da justiça do trabalho ampliada em face da EC n. 20/98". Revista LTr. São Paulo, n. 63-02/170, fev. 1999.

"Competência da justiça do trabalho ampliada em face da EC n. 20/98".

Revista LTr. São Paulo, n. 63-02/170, fev. 1999.

MERÇON, Paulo Gustavo de Amarante. "A sentença trabalhista e o efeito anexo condenatório das contribuições previdenciárias". In: LAGE, Emerson José Alves; LOPES, Mônica Sette (coord.). Execução previdenciária aspectos jurisprudenciais e doutrinários. Belo Horizonte: Del Rey, 2003.

MESSA, Ana Flávia. Direito Tributário: direito material. 3aㅗ ed. São Paulo: Rideel, 2009. MIRANDA, Jediael Galvão. Direito da Seguridade Social. Rio de Janeiro: Elsevier, 2007.

MORAES, Alexandre de. Direito Constitucional. 18 ${ }^{\mathrm{a}}$ ed. São Paulo: Atlas, 2005.

MOREIRA, José Carlos Barbosa. "Reflexões Críticas Sobre uma Teoria da Condenação Civil". In Temas de Direito Processual Civil - 1a Série. São Paulo, Saraiva, 1977.

MORETI, Wlademar. Os descontos previdenciários nas ações trabalhistas. RPS $247 / 392$.

MOUSSALLÉM, Tárek Moysés. Fontes do direito tributário. São Paulo: Noeses, 2008. NASCIMENTO, Amauri Mascaro. Curso do direito do trabalho: história e teoria geral do direito do trabalho: relações individuais e coletivas do trabalho. 26 ${ }^{\mathbf{a}}$ ed. São Paulo: Saraiva, 2011.

NASCIMENTO, Ricardo de Castro. "Efeitos previdenciários da sentença trabalhista". Revista de Direito Social, n. 17, jan./mar. de 2005. 
NERY JÚNIOR, Nelson. NERY, Rosa Maria de Andrade. Código de Processo Civil Comentado. 13를 ed. São Paulo: Revista dos Tribunais, 2013.

OLIVEIRA, Carlos Henrique de. Da tutela das informações sociais do trabalhador à garantia efetiva de acesso aos benefícios previdenciários. 256 folha. Tese Universidade de São Paulo, Faculdade de Direito do Largo de São Francisco. São Paulo, Janeiro de 2013.

OLIVEIRA, Francisco Antonio de. Curso de direito do trabalho. São Paulo: LTr, 2011.

OLIVEIRA, luri Cardoso de. GFIP trabalhista e alimentação da base de dados do Cadastro Nacional de Informações Sociais. Conteúdo Jurídico. Brasília-DF: 17 maio 2012. Disponível em: <http://www.conteudojuridico.com.br/?artigos\&ver=2.37005\&seo=1>. Acesso em: 16 nov. 2014.

ORAIS, Ocelio de Jesus. Execução previdenciária trabalhista e procedimentos práticos. $1^{\text {a }}$ ed. São Paulo: LTr, 2010.

PAIXÃO, Fábio Eduardo Bonisson. "As contribuições previdenciárias e a competência da justiça do trabalho". In: LAGE, Emerson José Alves; LOPES, Mônica Sette (coord.). Execução previdenciária aspectos jurisprudenciais e doutrinários. Belo Horizonte: Del Rey, 2003.

PAULSEN, Leandro. Curso de Direito Tributário. $2^{\mathrm{a}}$ ed. Porto Alegre: Livraria do Advogado, 2008.

PEREIRA, Cícero Rufino. "A competência para executar a contribuição previdenciária devida no curso do vínculo de emprego reconhecido em decisão trabalhista". Suplemento Trabalhista LTr nำ137/02, p. 649.

PEREIRA DE CASTRO, Carlos Alberto, \& LAZZARI, João Batista. "Contribuição à Seguridade Social em Razão das Decisões Proferidas pela Justiça do Trabalho e sua Execução". In Revista LTr, São Paulo, LTr, n. 63-02/173-182.

REALE, Miguel. Lições Preliminares de Direito. São Paulo: Saraiva, 2003.

ROCCO, Alfredo. La Sentenza Civile. Milano: Giuffrè, 1962.

ROCHA, Valdir de Oliveira. Determinação do Montante do Tributo. $2^{2}$ ed. São Paulo: IOB, 1992.

RODRIGUES PINTO, José Augusto. "Os Graves Embaraços Processuais da Emenda Constitucional n. 20/98”. In Revista Ltr, São Paulo, Ltr, n. 63-05/599-609.

ROUSSEAU, Jean-Jaques. Discurso sobre a Origem da Desigualdade entre os Homens. Disponível em http://www.dominiopublico.gov.br/download/texto/cv000053.pdf, consulta em 21/11/2014, às 22hs.

SAAD, Eduardo Gabriel. et. al. Curso de Direito Processual do Trabalho. 5a ed. São Paulo: LTR, 2007.

SABBAG, Eduardo. Manual de Direito Tributário. 3ª ed. São Paulo: Saraiva, 2011. 
SANDIM, Emerson Odilon. Novos perfis da execução previdenciária na Justiça do Trabalho. Sinergia entre a Constituição e a Lei 10.035. Exegese sistêmica como meta de otimização. Jus Navigandi. Teresina, ano 5, n. 47, 1 nov. 2000. Disponível em: <http://jus.com.br/revista/texto/1442>. Acesso em: 14/10/2011.

SANTI, Eurico Marcos Diniz de. Decadência e prescrição no direito tributário. São Paulo: Max Limonad, 2001.

SAVARIS, José Antonio. Direito processual previdenciário. 3aㅡ ed. Curitiba: Juruá, 2011.

SCHOUERI, Luís Eduardo. Direito tributário. São Paulo: Saraiva, 2011.

SCHOUERI, Luís Eduardo; CONTRUCCI, Gustavo Emílio. "Verdade Material no Processo Administrativo Tributário". In: ROCHA, Valdir de Oliveira (coord.). Processo administrativo fiscal. v. 3. São Paulo: Dialética, 1998.

SEVERINO, Antônio Joaquim. Metodologia do trabalho científico. 23aㅡ ed. SÃO PAULO: Cortez, 2007.

SILVA, Antônio Álvares da. A Justiça do Trabalho e o recolhimento das contribuições previdenciárias. São Paulo: LTr, 1999.

SILVA, Bruno Freire e. "Alguns aspectos processuais da execução previdenciária na justiça do trabalho". In: LEITÃO, André Studart; MEIRINHO, Augusto Grieco Sant'Anna (coord.). Prática previdenciária: a defesa do INSS em juízo. São Paulo: Quartier Latin, 2008.

SILVA, José Afonso. Aplicabilidade das normas constitucionais. $3^{a}$ ed. São Paulo: Malheiros, 1999.

TEIXEIRA FILHO, Manoel Antonio. Execução no processo do trabalho. São Paulo: LTr, 2001.

THEODORO, Humberto Junior. Curso de Direito Processual Civil. $38^{\underline{a}}$ ed. Rio de Janeiro: Forense, 2002.

VIANNA, João Ernesto Aragonés. Curso de direito previdenciário. 4⿳a ed. São Paulo: Atlas, 2011.

VILANOVA, Lourival. "Norma jurídica - proposição jurídica (significação semiótica)". In: Revista de Direito Público. São Paulo: Revista dos Tribunais, 1982.

Causalidade e relação no direito. São Paulo: Revista dos Tribunais, 2000. 